\title{
Status and Trends of Wetland Studies in Canada Using Remote Sensing Technology with a Focus on Wetland Classification: A Bibliographic Analysis
}

\author{
S. Mohammad Mirmazloumi ${ }^{1, *(1)}$, Armin Moghimi ${ }^{2}\left(\mathbb{D}\right.$, Babak Ranjgar $^{2}\left(\mathbb{D}\right.$, Farzane Mohseni $^{2}(\mathbb{D}$,

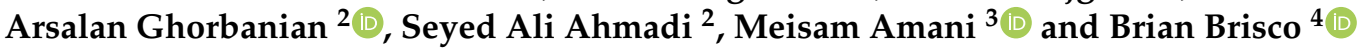 \\ 1 Centre Tecnològic de Telecomunicacions de Catalunya (CTTC/CERCA), Division of Geomatics, Av. Gauss 7 , \\ E-08860 Castelldefels, Barcelona, Spain \\ 2 Department of Remote Sensing and Photogrammetry, Faculty of Geodesy and Geomatics Engineering, \\ K. N. Toosi University of Technology, Tehran 1996715433, Iran; moghimi.armin@email.kntu.ac.ir (A.M.); \\ babakranjgar@alumni.kntu.ac.ir (B.R.); farzanemohseni@email.kntu.ac.ir (F.M.); \\ a.ghorbanian@email.kntu.ac.ir (A.G.); s.a.ahmadi@email.kntu.ac.ir (S.A.A.) \\ 3 Wood Environment \& Infrastructure Solutions, Ottawa, ON K2E 7L5, Canada; meisam.amani@woodplc.com \\ 4 The Canada Center for Mapping and Earth Observation, Ottawa, ON K1S 5K2, Canada; \\ brian.brisco@canada.ca \\ * Correspondence: sm.mirmazloumi@cttc.es
}

Citation: Mirmazloumi, S.M.; Moghimi, A.; Ranjgar, B.; Mohseni, F.; Ghorbanian, A.; Ahmadi, S.A.; Amani, M.; Brisco, B. Status and Trends of Wetland Studies in Canada Using Remote Sensing Technology with a Focus on Wetland Classification: A Bibliographic Analysis. Remote Sens. 2021, 13, 4025. https://doi.org/10.3390/rs13204025

Academic Editor: Nereida Rodriguez-Alvarez

Received: 12 August 2021

Accepted: 6 October 2021

Published: 9 October 2021

Publisher's Note: MDPI stays neutral with regard to jurisdictional claims in published maps and institutional affiliations.

Copyright: (c) 2021 by the authors. Licensee MDPI, Basel, Switzerland. This article is an open access article distributed under the terms and conditions of the Creative Commons Attribution (CC BY) license (https:// creativecommons.org/licenses/by/ $4.0 /)$.
Abstract: A large portion of Canada is covered by wetlands; mapping and monitoring them is of great importance for various applications. In this regard, Remote Sensing (RS) technology has been widely employed for wetland studies in Canada over the past 45 years. This study evaluates meta-data to investigate the status and trends of wetland studies in Canada using RS technology by reviewing the scientific papers published between 1976 and the end of 2020 (300 papers in total). Initially, a meta-analysis was conducted to analyze the status of RS-based wetland studies in terms of the wetland classification systems, methods, classes, RS data usage, publication details (e.g., authors, keywords, citations, and publications time), geographic information, and level of classification accuracies. The deep systematic review of 128 peer-reviewed articles illustrated the rising trend in using multi-source RS datasets along with advanced machine learning algorithms for wetland mapping in Canada. It was also observed that most of the studies were implemented over the province of Ontario. Pixel-based supervised classifiers were the most popular wetland classification algorithms. This review summarizes different RS systems and methodologies for wetland mapping in Canada to outline how RS has been utilized for the generation of wetland inventories. The results of this review paper provide the current state-of-the-art methods and datasets for wetland studies in Canada and will provide direction for future wetland mapping research.

Keywords: Canada; classification; remote sensing; wetland

\section{Introduction}

Wetlands are ecosystems where terrestrial and aquatic regions meet and share some characteristics. Wetlands also contain water for some periods of a year and are characterized by the presence of water, hydric soil, and specific vegetation adapted to a wet environment [1,2]. Wetlands are invaluable natural resources that provide exceptional benefits to humans and the surrounding environment [2]. Due to numerous environmental services of wetlands, including carbon sequestration [3], water purification [4], sediment filtration [5], soil conservation [6], and other critical services, wetlands have been called the "kidneys" of nature [7]. Additionally, from an economic perspective, wetlands are important due to their extensive applications for recreational activities [8], fish and shellfish aquacultures [9], flood mitigation [10], and providing diverse wildlife habitat $[11,12]$. Despite their numerous benefits, wetlands have been threatened by climate 
change, natural catastrophic events (i.e., wildfire), and anthropogenic activities, such as intense irrigation practices, water drainage, groundwater extraction, and replacement by urban and agricultural landscapes [13]. Therefore, it is vital to obtain precise, reliable, and up-to-date information about the different characteristics of wetlands (i.e., extent, type, health, and status).

Traditionally, wetland mapping was conducted by collecting airborne photographs and in situ data through intensive field surveys $[14,15]$. Although these methods were very accurate, they were resource-intensive and practically infeasible for large-scale studies with frequent data collection necessities. Consequently, advanced Remote Sensing (RS) techniques were proposed for wetland mapping and monitoring [2,16-18]. RS systems provide frequent Earth Observation (EO) datasets with diverse characteristics and broad area coverage, making them attractive to map and monitor wetlands' dynamics from local to global scales through time $[2,19,20]$. However, it should be noted that the possibility of obtaining reliable information about wetlands using RS data does not obviate the necessity of collecting in situ data, and their incorporation shall provide more profound results.

Passive and active RS systems capture EO data in different parts of the electromagnetic spectrum. In this regard, aerial [21-23], multispectral [18,24-27], Synthetic Aperture Radar (SAR) [28-31], hyperspectral [20,32], Digital Elevation Model (DEM) [33-36], and Light Detection and Ranging (LiDAR) point cloud datasets [36-38] have been extensively used separately or in conjunctions for wetland mapping. Since each of these data sources acquire $\mathrm{EO}$ data in different parts of the electromagnetic spectrum, they provide diverse information about the spectral and physical characteristics of wetlands [39]. Moreover, deployment of these sensors on airborne, spaceborne, and Unmanned Aerial Vehicle (UAV) platforms allows recording EO data over wetlands with different spatial resolutions and coverages. Finally, the integration of RS data with machine learning algorithms provides an excellent opportunity to fully exploit RS data for accurate wetland mapping and monitoring tasks $[40,41]$.

Machine learning algorithms allow extracting and interpreting RS data automatically and robustly to map wetlands and derive relevant information about the wetlands' condition. For instance, Random Forest (RF) [42-45], Support Vector Machine (SVM) [46-49], Maximum Likelihood (ML) [50-53], Classification and Regression Tree (CART) [35,36], and Deep Learning (DL) $[21,27,40,54]$ algorithms have been implemented to produce highquality wetland maps. In this regard, both pixel-based and object-based approaches have been applied to exploit the most delicate possible information about wetlands by integrating RS data and machine learning algorithms [55-62]. Moreover, studies [21,40,41,47,48,63] were also dedicated to assessing the performance of machine learning algorithms for accurate wetland mapping and monitoring to elucidate the path for other interested researchers all around the globe.

Global wetland extents were predicted to be from approximately 7.1 million $\mathrm{km}^{2}$ to 26.6 million $\mathrm{km}^{2}$ [64] and $25 \%$ of globally documented wetlands have been recorded over Canada, covering approximately $14 \%$ of the total Canadian terrestrial surface [65]. Wetlands are extended across Canada, with the greatest concentration in northern regions. The Northwest Territories (NT), Ontario (ON), and Manitoba (MB) provinces contain the highest coverage of wetlands [66]. Considering the environmental and economic benefits of wetlands, as well as the immense wetland extent in Canada, it is essential to produce precise wetland inventories for conservation and sustainable developments. Accordingly, different Canadian associations have categorized wetland types based on their morphology, hydrology, hydrochemistry, plant communities, soil and sediment characteristics, depth, productivity, and wildlife usages to establish practical guidelines to study and monitor wetlands [67]. One of these categorizations that has received much attention is the Canadian Wetland Classification System (CWCS), by which wetlands are divided into five classes: bog, fen, marsh, swamp, and shallow water [67].

Due to the importance of wetlands for the Canadian environment, many studies have been conducted to produce wetland inventories from local to national scales using different 
types of EO datasets and machine learning algorithms [40,41,68-70]. For instance, the study by [23] was an early study that employed aerial imagery for wetland mapping in Canada. Later, a combination of multi-source RS datasets, including aerial, SAR, DEM, and optical satellite images, were employed in most of the Canadian provinces for wetland classification [7,71-73]. A significant effort has also been made to produce nation-wide wetland inventories using cloud computing methods. For instance, [68] created the first Canada-wide wetland inventory with $30 \mathrm{~m}$ spatial resolution and based on the CWCS categories. In this regard, they processed over 30,000 Landsat-8 images within the Google Earth Engine (GEE) cloud computing platform. Afterwards, two generations of Canadian wetland inventories with $10 \mathrm{~m}$ spatial resolution were produced by combining Sentinel- 1 and Sentinel-2 images within GEE $[69,70]$. However, they have addressed various uncertainties regarding the large-scale and wetland types mapping.

Until now, several studies have been conducted to review the wetland studies which have been conducted using RS technology. For instance, a two-part review $[74,75]$ provided a guide on how RS data can be used to quantify boreal wetland extent and monitor drivers of change on wetland environments, along with a technical review of RS data processing and analysis techniques. The authors of $[2,76]$ also comprehensively discussed the characteristics and importance of wetlands, as well as the advantages and disadvantages of various RS sensors and methods used in wetland research. Additionally, [18] considered the global application of SAR data for wetland mapping. Furthermore, [17] conducted a meta-analysis of wetland classification focusing on the publication trends in North America. However, there is a need for a national-scale, bibliographic analysis of efforts to map wetlands with RS data within and across Canada. Therefore, this review paper aims to provide necessary information on (1) identifying and categorizing wetland studies using RS data, (2) illustrating the geographical distribution of inventories, (3) discussing the classification techniques for wetland mapping, (4) assessing RS data applications, and (5) discussing classification accuracy through a systematic literature search and meta-analysis of studies conducted in Canada. Additionally, a comprehensive review of lead- and coauthors and their affiliated universities/institutions who have published research studies in Canada is provided. Keywords and citation surveys have also been individually analyzed.

\section{Wetland Classification Systems in Canada}

Multiple wetland classification systems have been proposed and utilized in Canada. The three well-known Wetland Classification Systems (WCS) are presented in Figure 1a. CWCS is the main system used across Canada. The Alberta Wetland Classification System (AWCS) is a customized form of CWCS for the Alberta province [77]. Both systems have the same wetland classes with the difference in forms and subclasses. The Enhanced Wetland Classification System (EWCS) is another system applied in Canada. This system divides the original five classes of the CWCS into 19 finer subclasses [78].

CWCS has emerged from a series of developments within the NWWG started in 1976 [79]. The second edition and final document of CWCS was released in 1997 [67], which classifies wetlands into five major classes and has additional characteristics features of form and sub-form. These forms can be further categorized regarding dominant vegetations. Each of the five classes of CWCS is briefly described below and summarized in Figure 1b. A more detailed description of each wetland class can also be found in [80,81].

Bog is a type of ombrogenous peatland, which means its major water source is precipitation [39]. Therefore, it is an acidic and low nutrient environment mostly covered with sphagnum moss, sedge, and ericaceous shrub species [82]. Bog's vegetation form may vary between open, shrubby, or treed depending on soil, hydrology, and nutrient characteristics.

Fen, another type of peatland, is similar to bog in terms of peat accumulation. However, its water source is not limited to precipitation like with bogs, but includes water surface flows and groundwater contributions to its moisture [82]. Fens are typically divided into two classes of rich fens and poor fens based on having contact with mineral-rich water and nutrient availability. The vegetation cover of poor fens is similar to bog, while 
sedges, brown moss, grass, and graminoids are the dominant vegetation species in rich fens. Nevertheless, all fens have minerotrophic indicator species meaning that they only grow in the right nutrient environments [80].

(a)

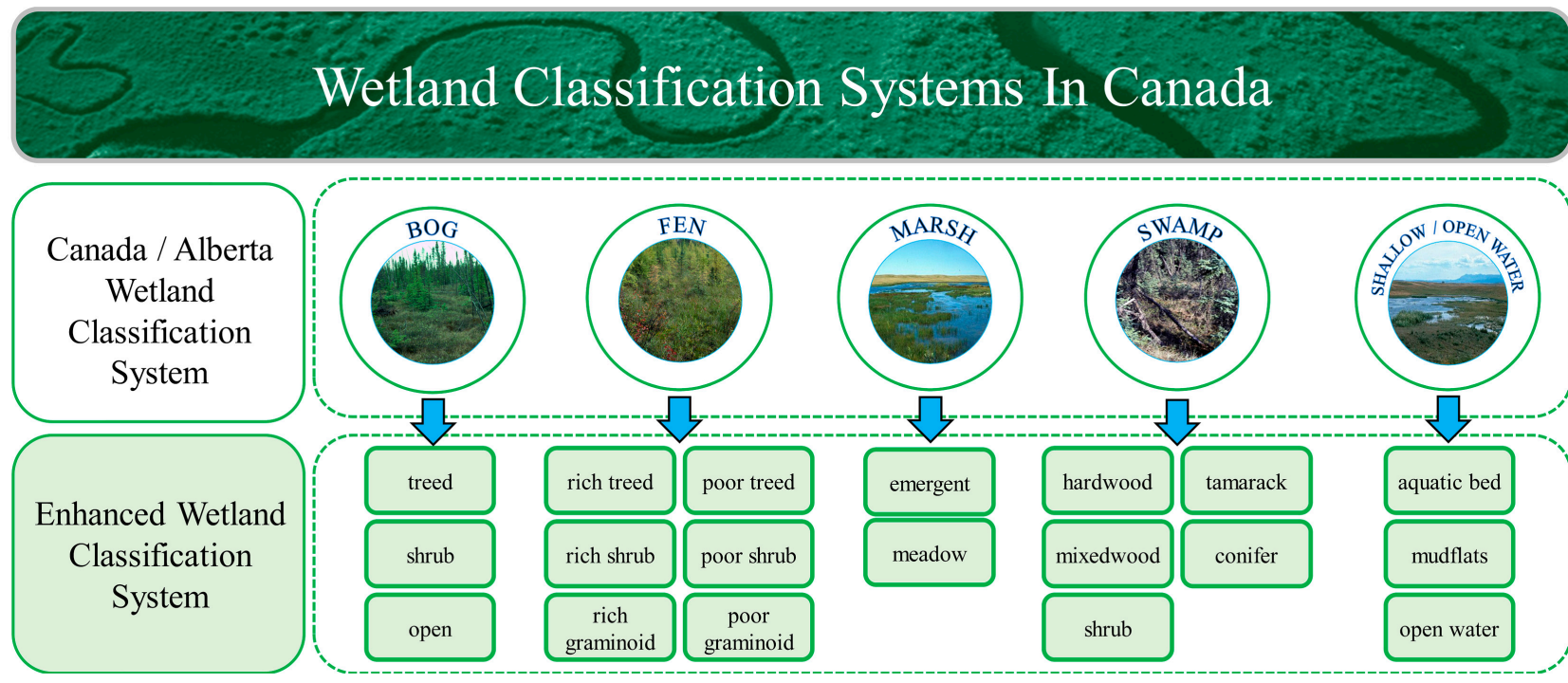

(b)

Organic

Mineral

\section{Canadian Wetland Classification System}

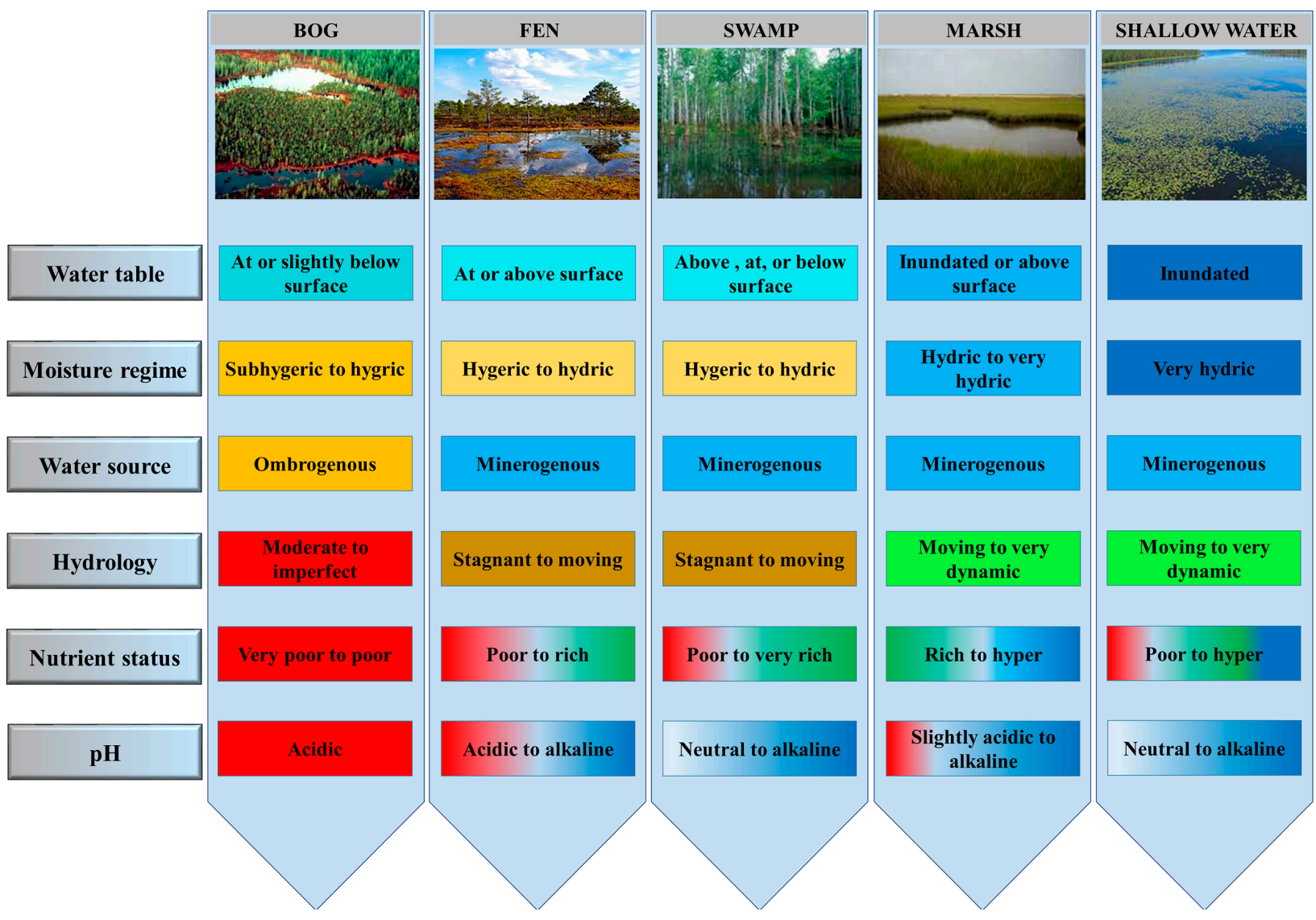

Figure 1. (a): The well-known Wetland Classification Systems used in Canada. (b): Wetland classes based on the CWCS.

Swamps exist in both mineral and peatland wetland types [80]. Swamps are often found in contact with other hydrological systems; hence they are difficult to identify. One of the distinguishing characteristics of swamps is that the woody vegetation (trees and 
shrubs) dominates the swamp environment (30\% up to 100\%) [82]. Additionally, the peat soil in swamps is composed of well-decomposed wooded species rather than the organic sphagnum or sedge-dominated peat in bogs and fens. The water table fluctuates in swamps, and they are not permanently saturated or inundated like bogs and fens; thus, the soil layer can be well-aerated [80].

Marsh is a type of mineral wetland class that experiences a high temporally periodical (seasonal/annual) rate of inundation. The hydrology inputs are from numerous sources, such as tides, water flow, groundwater, surface runoff, precipitation, and flooding. The variety of dissolved mineral inputs and freshening ventilation lead to high productivity and a diverse range of vegetation species [80]. Marsh vegetation communities are often comprised of emergent aquatic types, such as rushes, sedges, grasses, broad-leaved emergent, floating, and submerged aquatic plants [83].

Shallow water is a semi-permanent to permanent water body with a water depth of fewer than $2 \mathrm{~m}$ during mid-summer [39]. However, mudflats might be exposed in occasions of water drawdown. Submerged aquatic and floating vegetation with the capability of adaptation to constant inundation are present in shallow waters [82].

\section{Method of Meta-Analysis}

Figure 2 shows the workflow of preparing the documents for content analyses in this review. The bibliographic database of the present review was attained through performing a title, abstract, and keywords systematic literature search of relevant articles in the two well-known scientific databases of Clarivate Analytics Web of Science and Elsevier Scopus. To this end, all the combinations of search words (see Table 1) were applied to select English language journal papers, conference papers, and review papers between 1975 and the end of 2020. For instance, the combination of "wetland", "Canada", and "remote sensing" was the first combination for the literature search. It is worth mentioning that "Canada" was separately considered to include those research papers conducted over the entire country of Canada, as well as papers in which the province name was not stated in the title, abstract, or keywords. Afterwards, the Preferred Reporting Item for Systematic Review and Meta-Analysis (PRISMA) checklist was applied to organize the collected documents [84]. First, all the results for each combination were separately examined, and then the duplicate documents were removed. Subsequently, the remaining corpus of documents was combined to generate a consolidated database that encompassed 686 papers. A title filtering was then performed to identify the duplicate documents obtained by different combinations, which led to 473 documents. Later, those documents that their source file was not found, along with irrelevant documents, were also excluded, which finally resulted in 300 remaining papers. Following this filtering step, the title, abstract, and keywords sections of the remaining papers were screened to distinguish papers associated with wetland mapping from other wetland studies. This was performed because further attributes (see Figure 2) were derived from wetland mapping-related papers as the primary focus of this review. Finally, all 300 papers were fully inspected to extract different attributes (see Table 2), such as year, study area, classification method, and data type, for further analyses (see Table A2). 


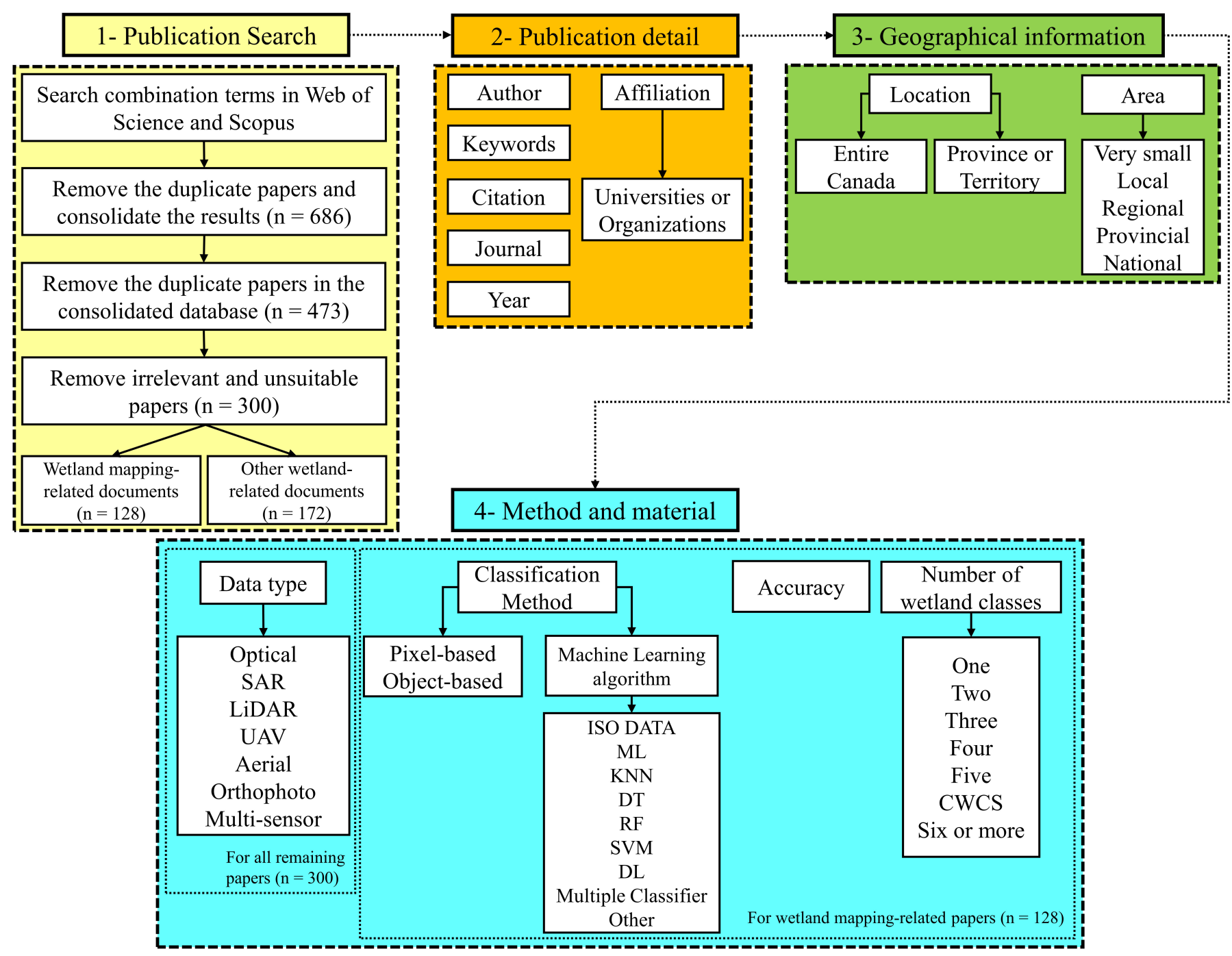

Figure 2. Workflow of preparing content analyses of this review paper.

Table 1. List of search words to prepare the procurements of this review.

\begin{tabular}{|c|c|c|c|}
\hline First Word & Second Word & & Third Word \\
\hline Wetland & $\begin{array}{l}\text { Canada } \\
\text { Newfoundland and Labrador (NL) } \\
\text { Ontario } \\
\text { Quebec (QC) } \\
\text { Nova Scotia (NS) } \\
\text { New Brunswick (NB) } \\
\text { Manitoba } \\
\text { British Columbia (BC) } \\
\text { Prince Edward Island (PE) } \\
\text { Saskatchewan (SK) } \\
\text { Alberta (AB) } \\
\text { Northwest Territories } \\
\text { Yukon (YT) } \\
\text { Nunavut (NU) }\end{array}$ & And & $\begin{array}{c}\text { Remote Sensing } \\
\text { Radar } \\
\text { Satellite }\end{array}$ \\
\hline
\end{tabular}


Table 2. The 14 attributes considered for content analysis of all 300 papers for further investigations.

\begin{tabular}{ccc}
\hline & Attribute & Categories \\
\hline 1 & First Author & Name \\
2 & Co-authors & Name \\
3 & Publication year & Value \\
4 & Citation & Value \\
5 & Paper type & Type: Journal, Conference \\
6 & Study area & Type: 13 provinces/territories and Canada \\
7 & Affiliation & Type: University, Organization \\
8 & Data type & Method \\
9 & Number of wetland classes & Type: Optical, SAR, LiDAR, UAV, Aerial, Orthophoto, Multi-sensor \\
10 & Classifier & Type: (Supervised, Unsupervised), (Object-based, Pixel-based) \\
11 & Journal & Value: One, Two, Three, Four, Five, CWCS, and Six or more \\
12 & Area extent & Type: 8 classifiers, multiple classifiers, and Other \\
13 & Accuracy & Name \\
14 & & Type: Very small, Local, Regional, Provincial, National \\
\end{tabular}

\section{Results and Discussion}

Several statistical analyses were first conducted in the following subsections based on the procedure defined in the method section. In addition to demonstrating the general characteristics of 300 RS-based wetland studies in Canada (e.g., publication details, geographical information, and RS datasets), a comprehensive survey and discussion of the meta-analysis status and trends were provided to present a comprehensive overview of 128 mapping studies. Policymakers can gain advantages from this overview in wetland mapping over Canada using RS technology.

\subsection{Publication Details}

\subsubsection{Number of Annual Publications}

Figure 3 shows a schematic summary of the distribution of published articles during the time-period studied period along with the number of journal and conference papers. Figure 3 also includes those journals that have published more than one paper in each time interval. It is worth noting that for the period 2006-2020, those journals that have published more than three papers are only provided. According to Figure 3, several clear-up conclusions can be drawn and summarized as follows. Over time, the number of published papers increased. As such, the distribution of articles shows a major positive trend in publications of wetland studies in Canada. A total of $9(3 \%), 14(4.7 \%), 10(3.4 \%), 37(12.4 \%)$, $43(14.4 \%), 62(20.7 \%)$, and $124(41.5 \%)$ papers were, respectively, published in 1976-1985, 1986-1995, 1996-2000, 2001-2005, 2006-2010, 2011-2015, and 2016-2020. These results show that the published articles gradually increased about $50 \%$ in the period 1976-2020.

After evaluating the time-level publication rates, we examined the number of publications for each year according to the study area. To this end, 300 articles were divided into 12 categories based on the Canadian provinces and territories, including $\mathrm{BC}, \mathrm{QC}$, SK, NU, MB, YT, NS, NL, AB, NT, NB, and ON. Figure 4 summarizes yearly trends in Canada's wetland publications according to the study area. Based on the results, there were no studies published from 1983 to 1987. It must be kept in mind that in this period, articles were presented in printed mode. Although many of them have been scanned into searchable formats and made available online, there may have been some other articles that were not scanned. Additionally, our extensive search of online resources indicates no studies published before 1987, and a small number of papers were published in early 2000 as well as in 2004. Almost 75\% of the total 300 papers were published after 2004. The year 2020, with a total of 15 papers, had the most published articles since 1976. Moreover, the years 2019, 2018, and 2017, with a total of 24 published articles, were the second years with the most papers published about RS-based wetland studies in Canada. 
Journal papers: 114

Conference papers: 10

\section{Remote Sensing (32)}

Canadian Journal of Remote Sensing (12)

IEEE Journal of Selected Topics in Applied

Earth Observations and Remote Sensing (6)

Hydrological Processes (6)

Remote Sensing of Environment (6)

Ecohydrology (4)

GIScience and Remote Sensing (3)

International Journal of Applied Earth

Observation and Geoinformation (3)

ISPRS Journal of Photogrammetry and

Remote Sensing (3)

International Journal of Remote Sensing (3)

Journal papers: 58

Conference papers: 4

Canadian Journal of Remote Sensing (8)

Remote Sensing (8)

Hydrological Processes (4)

International Journal of Remote Sensing(3)

Remote Sensing of Environment (3)

Wetlands (3)

Wetlands Ecology and Management (2)

$1976-1985 \square$
$1986-1995 \square$
$1996-2000 \square$
$2001-2005$$\quad \begin{aligned} & 2006-2010 \\ & 2011-2015 \\ & 2016-2020\end{aligned}$

Journal papers: 2

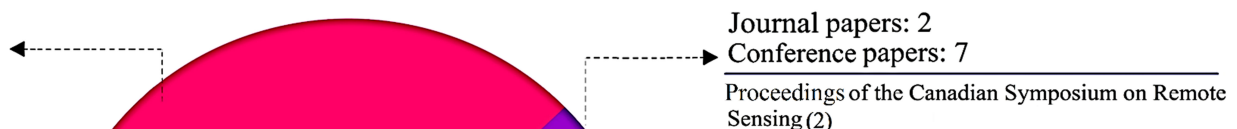

Proceedings of the Canadian Symposium on Remote

Journal papers: 13

Conference paper: 1

Canadian Journal of Remote Sensing (2)

International Journal of Remote Sensing (2)

IEEE-International Geoscience and Remote Sensing Symposium (IGARSS) (2)

Journal papers: 9

Conference paper: 1

Canadian Journal of Remote Sensing (2)

Journal of Geophysical Research Atmospheres (2)

Journal papers: 27

Conference papers: 10

Canadian Journal of Remote Sensing (7)

Hydrological Processes (3)

Remote Sensing of Environment (3)

IAHS-AISH Publication (2)

Journal papers: 38

Conference papers: 5

International Journal of Remote Sensing (2)

Canadian Journal of Remote Sensing (12)

Hydrological Processes (4)

Environmental Monitoring and Assessment (2)

IEEE Transactions on Geoscience and Remote Sensing (2) Jurnal of Geophysical Research Atmospheres (2) Symposium (IGARSS) (2)

Figure 3. Schematic summary of the number and percentage of RS-based wetland publications along with a list of the key journals and the corresponding number of studies published in each for various time intervals.

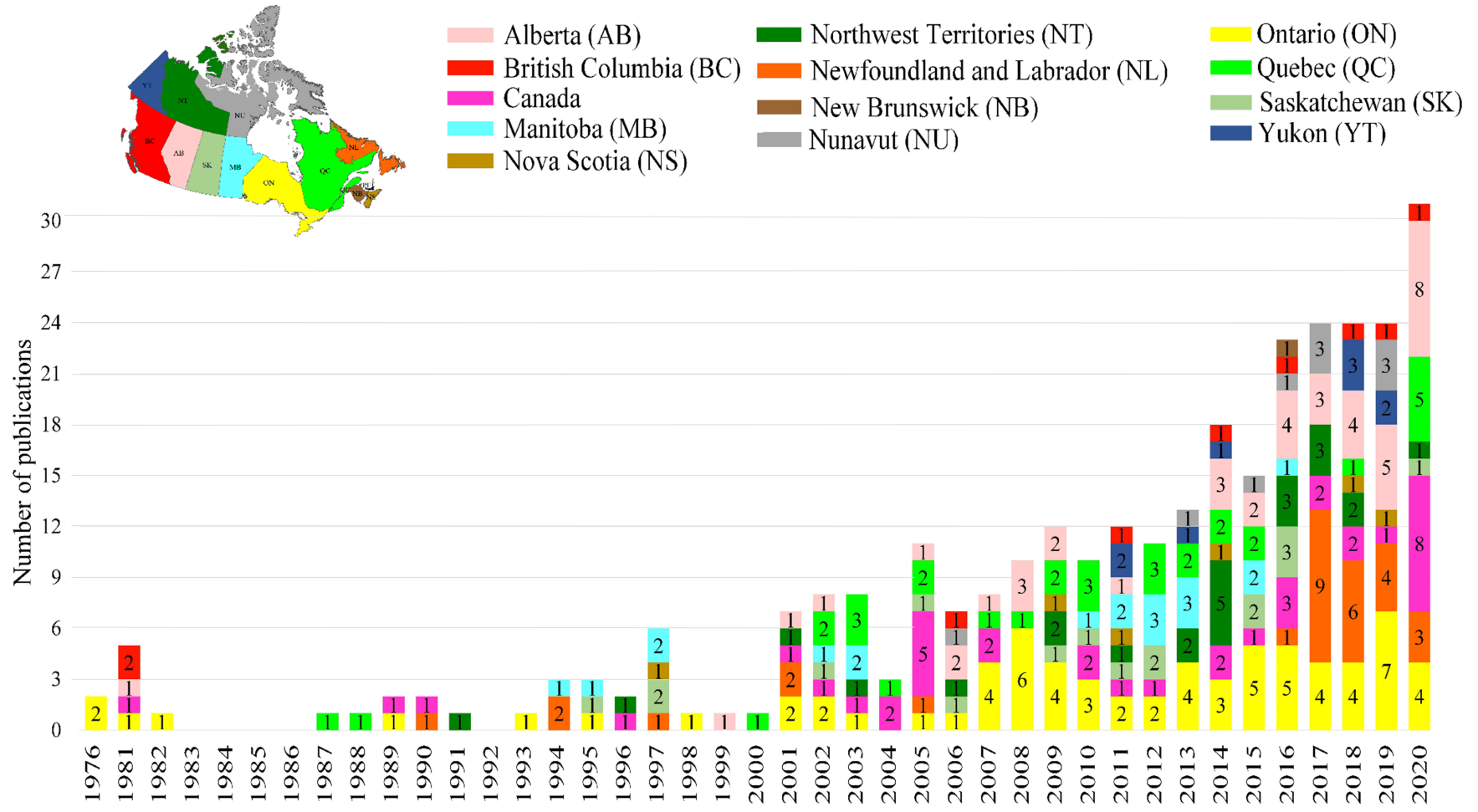

Figure 4. The number of publications on RS-based wetlands studies in Canada for each year (since 1976) according to the study area (i.e., Canadian provinces/territories).

After 2000, a wide range of studies has been conducted in different provinces of Canada so that the study on the YT and NB were started in 2011 and 2016, respectively. As such, the wetlands of all 12 Canadian provinces/territories were considered as the study area. After 2017, in most years, a large number of studies were developed in NL, ON, and $\mathrm{AB}$ (see Figure 4). We found that 22\% (23 out of 103 articles), 18\% (19 out of 103 articles), 
and $18 \%$ (18 out of 103 articles) of the studies published in 2017-2020 were, respectively, conducted in $\mathrm{NL}, \mathrm{AB}$, and $\mathrm{ON}$.

\subsubsection{Keyword Analysis}

Figure 5 a illustrates the word cloud generated from the keywords' frequencies. The size of each keyword is related to the frequency that a keyword has been used in all 300 papers. Considering the combination for the literature search, the biggest keywords were "Wetland" and "Remote Sensing". Since the reviewed papers came from different journals with various formats, the keywords were not consistent. Therefore, we preprocessed the words before feeding them into the word-cloud generator. For this purpose, all plural keywords were converted to their singular form. Lower- and upper-case words were justified, and all the first letters were capitalized. For instance, "Remote sensing", "landsat", and "wetland" were changed to "Remote Sensing", "Landsat", and "Wetland", respectively. With this substitution, the word cloud generator algorithm considered such words the same (e.g., "landsat", "Landsat", "LandSat", and "LANDSAT" were considered as one keyword of Landsat). The acronyms and their expanded versions were justified; then, acronyms were used in the word cloud. Finally, due to the similar meaning of some words, such as UAV and Unmanned Aerial System (UAS), they were merged and one of them was used.

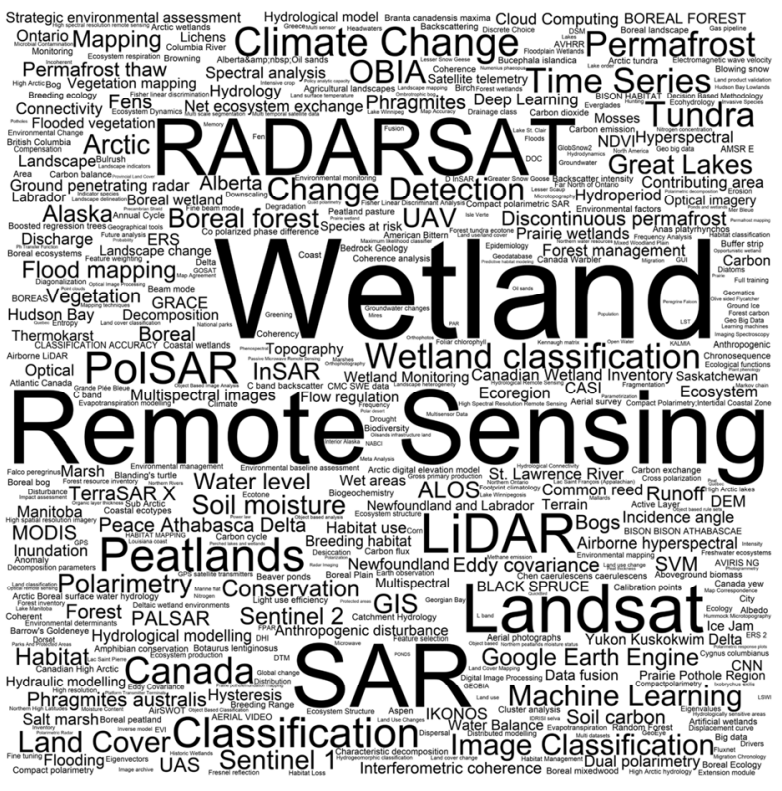

(a)

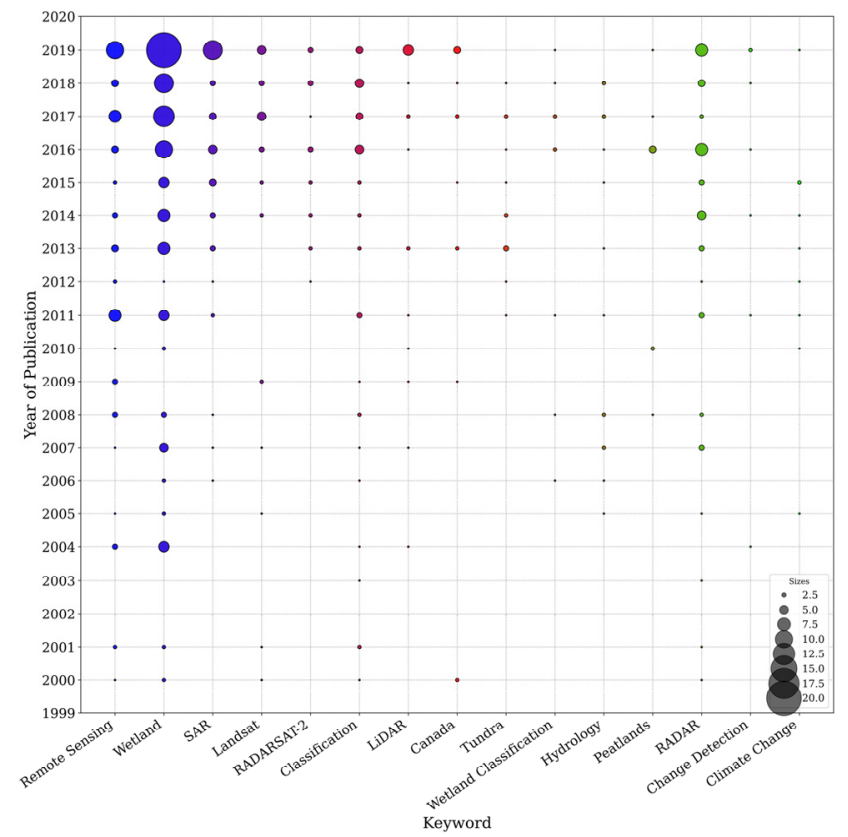

(b)

Figure 5. (a): Keyword frequencies of all the reviewed papers about RS-based wetland studies and (b): how many times a keyword has been repeated through the years.

To find out how many times a keyword has been used throughout the years, Figure $5 b$ scatters the keywords per year. Each dot shows that the keyword has been mentioned in papers published in the corresponding year, and its size represents its frequency. Colors were selected arbitrarily for better visualization. The vertical axis representing the publication year was limited to 2000-2020 and the publications before 2000 were not displayed in this figure. As is clear, "wetland(s)" and "remote sensing" were the most frequently used keywords followed by "synthetic aperture radar (SAR)", "Landsat", and "RADARSAT-2."

\subsubsection{Journal and Conference Analyses}

In total, the 300 papers were published in 68 journals and 13 well-known international conferences. The journal publishers, as well as journals and conference papers, which 
published more than three times, are illustrated in Figure 6. The Canadian Journal of Remote Sensing and Remote Sensing (MDPI) with 46 and 40 papers were the top two journals, respectively. Moreover, Hydrological Processes, Remote Sensing of Environment, and International Journal of Remote Sensing with 19, 14, and 12 papers, respectively, were the other journals of interest in this field. In terms of the publisher center, most of the journal papers were published by Taylor \& Francis followed by Wiley, MDPI, and Elsevier. Less than $8 \%$ of the journal papers were published by the SPIE, IEEE, and Springer. Among the conference papers, the IEEE IGARSS with 16 papers is the top conference for publishing papers on wetland studies in Canada, where the ISPRS Archive was the second one with 10 papers.

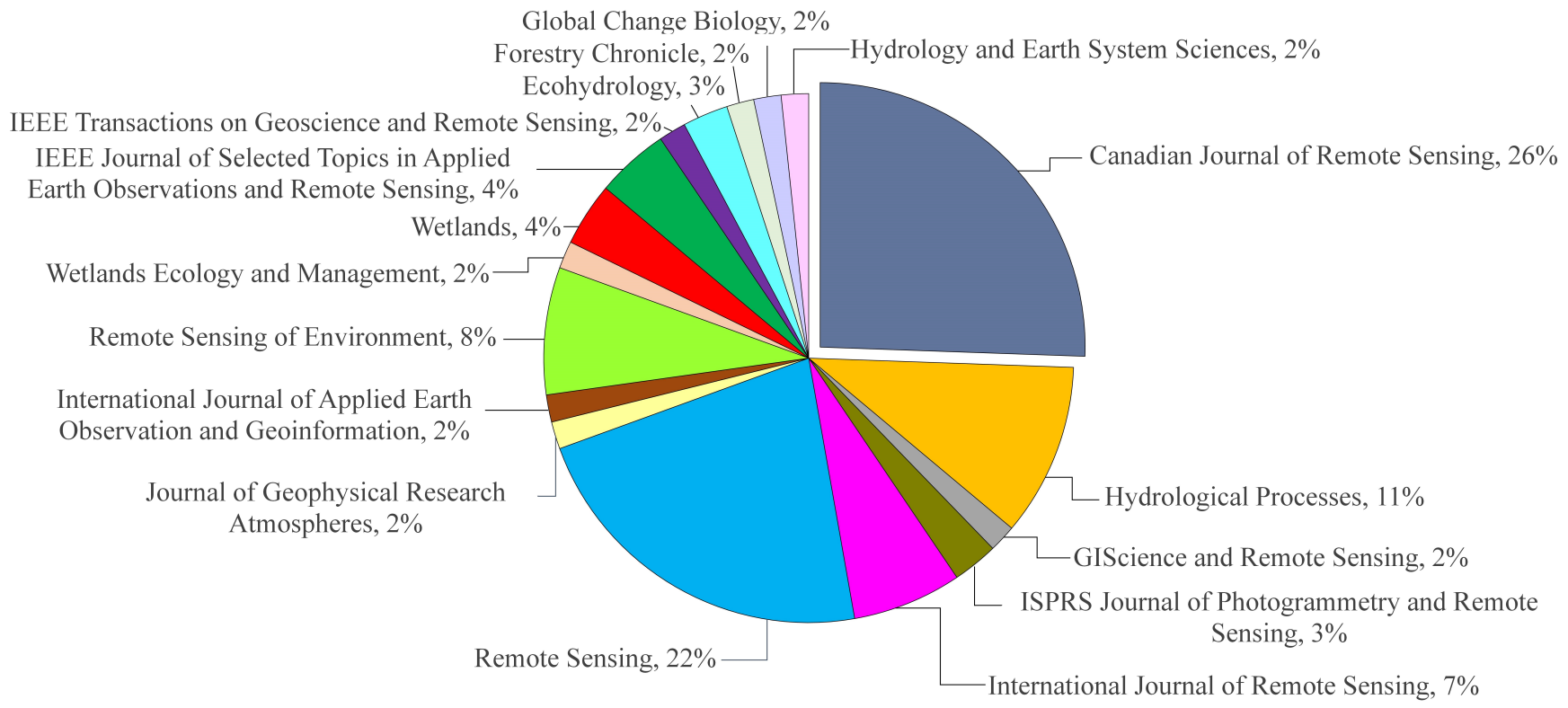

(a)

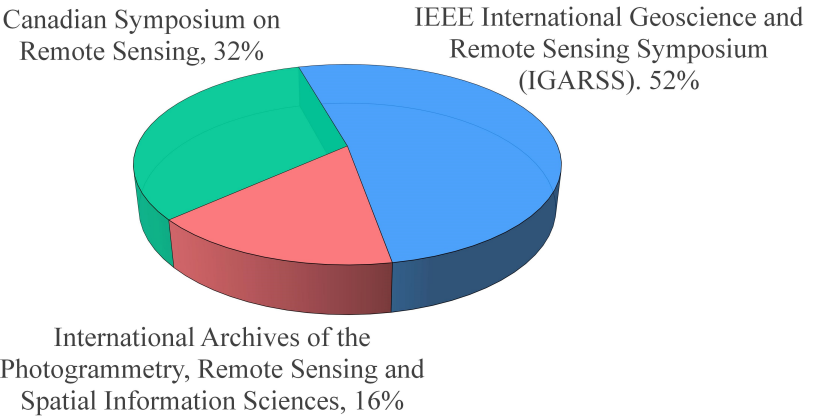

(b)

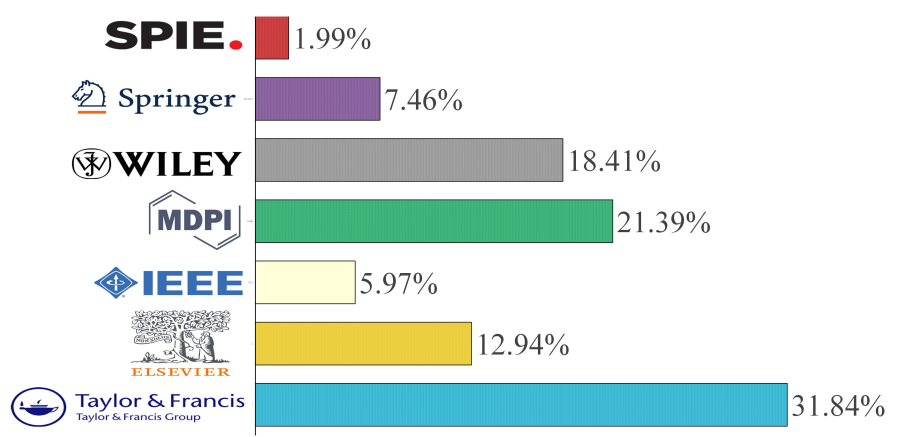

(c)

Figure 6. Percentage of published RS-based wetland studies in Canada per (a) journal, (b) international conference, and (c) publisher.

\subsubsection{First and Co-Authors Analysis}

This section summarizes the number of authors and co-authors in word-cloud, respectively. All the 300 papers were written by 210 unique first authors, and there were 943 co-authorships by 614 unique co-authors. Figure 7 displays all the authors who have more than three papers in their contributions, whether as author or co-author. Brisco B. is the lead author with a considerable difference from others. Additionally, Amani M. and Mahdianpari M. with 10 contributions are at the top as first authors. Brisco B. and Salehi B. with about 35 and 25 papers, also have the highest number of papers, respectively. 


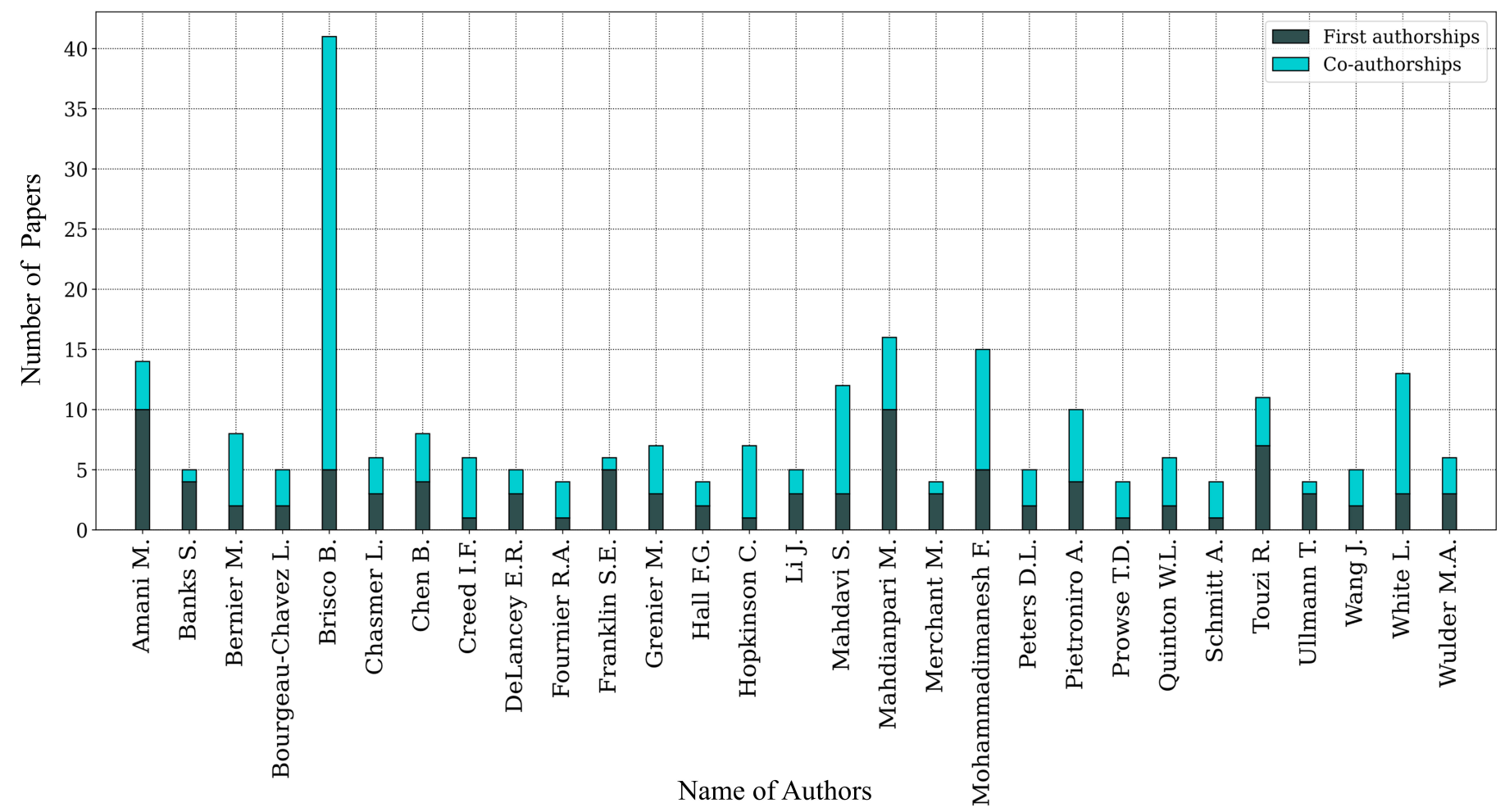

Figure 7. Authors who have contributed more than three papers as first author or co-author (alphabetically ordered).

\subsubsection{Affiliation Analysis}

In Table 3, the top universities and institutions and their contribution are summarized. For this analysis, only institutions with three or more publications were considered. Memorial University of Newfoundland has the highest number of publications in wetland classification. However, multiple institutions from ON (e.g., Canada Centre for Remote Sensing and National Wildlife Research Centre) also have a significant contribution with a total number of 61 papers.

Table 3. The detailed information of affiliations analysis.

\begin{tabular}{|c|c|c|c|c|}
\hline Institute & Country/Province & Papers & Citation & CPP \\
\hline Memorial University of Newfoundland & NL & 29 & 787 & 27.14 \\
\hline Canada Centre for Remote Sensing & $\mathrm{ON}$ & 15 & 952 & 63.47 \\
\hline INRS & QC & 11 & 419 & 38.09 \\
\hline University of Saskatchewan & SK & 10 & 423 & 42.3 \\
\hline Ducks Unlimited Canada & $\mathrm{MB}$ & 9 & 23 & 2.56 \\
\hline University of Western Ontario & $\mathrm{ON}$ & 9 & 279 & 31 \\
\hline University of Alberta & $\mathrm{AB}$ & 9 & 236 & 26.22 \\
\hline Canada Center for Mapping and Earth Observation & $\mathrm{ON}$ & 9 & 71 & 7.89 \\
\hline National Wildlife Research Centre & ON & 8 & 105 & 13.125 \\
\hline Carleton University & $\mathrm{ON}$ & 7 & 176 & 25.14 \\
\hline Université de Sherbrook & QC & 7 & 85 & 12.14 \\
\hline Canadian Wildlife Service of Environment Canada & QC & 6 & 218 & 36.33 \\
\hline University of Toronto & $\mathrm{ON}$ & 6 & 150 & 25 \\
\hline National Water Research Institute, Environment Canada & SK & 6 & 416 & 69.33 \\
\hline McMaster University & $\mathrm{ON}$ & 5 & 93 & 18.6 \\
\hline University of New Brunswick & NB & 5 & 26 & 5.2 \\
\hline University of Calgary & $\mathrm{AB}$ & 5 & 270 & 54 \\
\hline University of Victoria & $\mathrm{BC}$ & 5 & 211 & 42.2 \\
\hline Wilfrid Laurier University & $\mathrm{ON}$ & 4 & 270 & 67.5 \\
\hline University of Guelph & $\mathrm{ON}$ & 4 & 106 & 26.5 \\
\hline University of Alaska Fairbanks & Alaska, U.S. & 4 & 85 & 21.25 \\
\hline
\end{tabular}


Table 3. Cont.

\begin{tabular}{|c|c|c|c|c|}
\hline Institute & Country/Province & Papers & Citation & CPP \\
\hline University of Lethbridge & $\mathrm{AB}$ & 4 & 44 & 11 \\
\hline McGill University & QC & 3 & 375 & 125 \\
\hline University of Waterloo & $\widehat{\mathrm{ON}}$ & 3 & 102 & 34 \\
\hline Trent University & $\mathrm{ON}$ & 3 & 48 & 16 \\
\hline Université Laval & QC & 3 & 110 & 36.67 \\
\hline Environment and Climate Change Canada & QC & 3 & 70 & 23.33 \\
\hline The University of British Columbia & $\mathrm{BC}$ & 3 & 65 & 21.67 \\
\hline University of California at Los Angeles & CA, U.S. & 3 & 39 & 13 \\
\hline Ontario Centre for Remote Sensing & ON & 3 & 26 & 8.67 \\
\hline Wood Environment \& Infrastructure Solutions & NL & 3 & 23 & 7.67 \\
\hline
\end{tabular}

In terms of citation, publications of the Canada Centre for Remote Sensing have attracted the greatest amount with a total citation of 952, followed by Memorial University of Newfoundland (787); University of Saskatchewan (423); INRS (419); National Water Research Institute, Environment Canada (416); and McGill University (375). Additionally, regarding Citation Per Paper (CPP), McGill University with a CPP of 125 is the highest. The next top institutions were the National Water Research Institute, Wilfrid Laurier University, and the Canada Centre for Remote Sensing having CPP values of 69.33, 67.5, and 63.46, respectively.

\subsubsection{Citation Analysis}

Citation analysis helps to ascertain prominent documents that significantly influence the corresponding field [85]. Furthermore, it also reflects the objectivity and quality of a paper by manifesting the number of attracted scholars to cite such a paper. Therefore, the citation number of all considered papers until the end of 2020 was extracted from Google Scholar to identify the high-contributing papers. It should be noted that earlier papers may have more citations than the recently published articles due to a more extended availability to the scientific community. Thus, the average citation per year was also calculated along with the total number of citations to reduce the effect of the elapsed time since publication. Table 4 presents the ten most cited papers devoted to wetland mapping in Canada. Based on Table 4, Ref. [27] was recognized as the most influential paper in the wetland studies conducted in Canada, in which the authors examined the applicability of various deep Convolutional Neural Networks (CNNs) for wetland mapping using high-resolution RS imagery.

Table 4. Highly cited papers devoted to wetland studies in Canada.

\begin{tabular}{|c|c|c|c|c|c|}
\hline Rank & First Author & $\begin{array}{c}\text { Average Number } \\
\text { of Citations } \\
\text { per Year }\end{array}$ & Total Citations & Publication Year & Region \\
\hline 1 & Mahdianpari et al. [27] & 44 & 132 & 2018 & Part of NL \\
\hline 2 & Mahdianpari et al. [86] & 37.5 & 75 & 2019 & Entire NL \\
\hline 3 & Kokelj and Jorgenson [87] & 30.37 & 243 & 2013 & - \\
\hline 4 & Mahdianpari et al. [44] & 29.75 & 119 & 2017 & Part of NL \\
\hline 5 & Touzi, R. [88] & 28.5 & 399 & 2006 & Part of ON \\
\hline 6 & Mahdavi et al. [2] & 24 & 72 & 2018 & - \\
\hline 7 & Delancey et al. [21] & 23 & 23 & 2020 & Part of $\mathrm{AB}$ \\
\hline 8 & Hird et al. [40] & 22.5 & 90 & 2017 & Part of $A B$ \\
\hline 9 & Connon et al. [89] & 18.28 & 128 & 2014 & Part of NT \\
\hline 10 & Amani et al. [68] & 17 & 34 & 2019 & Entire Canada \\
\hline
\end{tabular}




\subsubsection{Number of Wetland Classes}

As mentioned, 128 out of the 300 papers were about wetland classification in Canada. These 128 papers were analyzed based on the number of wetland classes they included (see Figure 8). Almost all the papers (i.e., 114 papers) used five or fewer wetland classes. In total, 40 articles focused on five wetland classes (i.e., based on CWCS). Then, the second highest amount (29) belongs to papers covering one wetland class. The number of papers considering two, three, and four wetland classes were 14, 20, and 12, respectively. A few studies considered more than five classes. For example, four papers mapped six and seven classes, and two papers considered eight classes. There were only three papers discussing a large number of wetland classes, including 11, 12, and 17 classes.

\begin{tabular}{cc}
\hline $\begin{array}{c}\text { \# wetland } \\
\text { classes }\end{array}$ & \# papers \\
\hline 1 & 29 \\
2 & 14 \\
3 & 20 \\
4 & 12 \\
5 & 40 \\
6 & 4 \\
7 & 4 \\
8 & 2 \\
11 & 1 \\
12 & 1 \\
17 & 1 \\
\hline
\end{tabular}

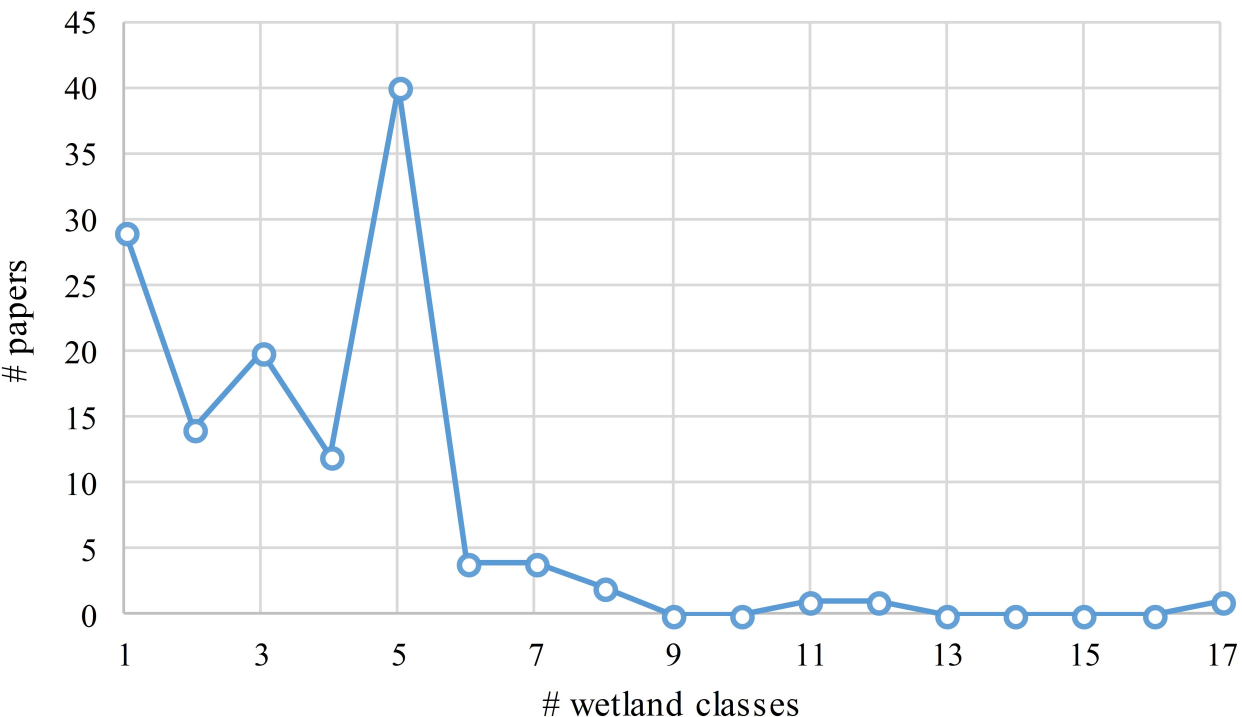

Figure 8. The number of papers based on the number of wetland classes included.

\subsubsection{Province- and Territories-Based Analysis}

The percentage of the papers based on the number of mapped wetland classes in each Canadian province/territory are illustrated in Figure 9. Note that articles that covered large regions and nationwide study areas were not considered in this analysis.

Since almost 90 percent of the papers considered five or fewer wetland types, the classes in Figure 9 were decided to be from one to five, and others were considered as having six or more classes. Furthermore, an extra category of CWCS was also considered to depict the percentage of papers that followed the CWCS specifications. The NL province had the highest number of published papers $(86.4 \%)$ based on CWCS specifications, followed by $\mathrm{NS}, \mathrm{BC}$, and YT ( 50\%). ON had the highest number of papers overall (36); however, none of them used CWCS. In addition, NB and SK were not studied in any CWCS-structured paper. Finally, the only paper studying wetlands in NU considered only one wetland class. 


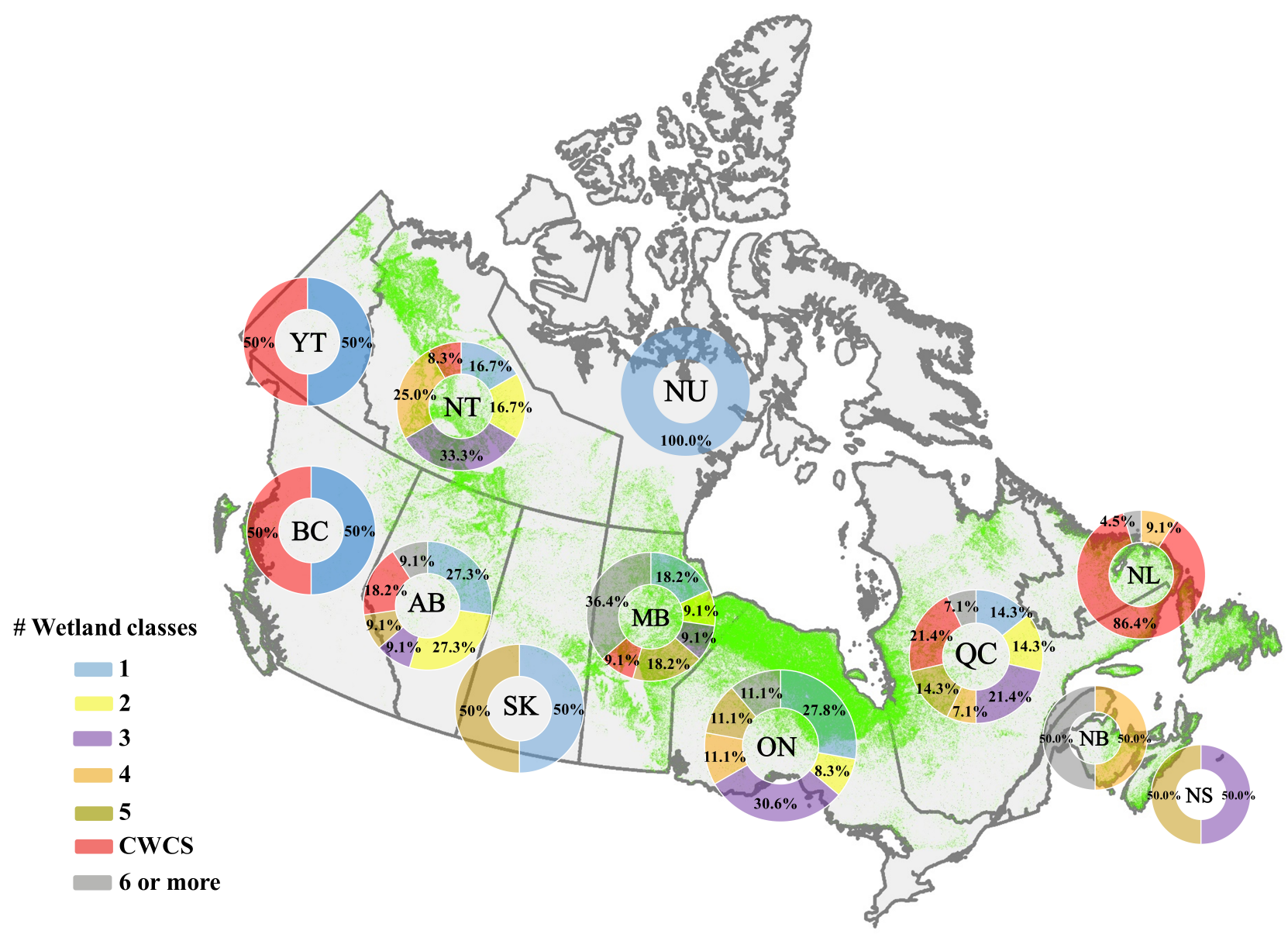

Figure 9. The province-based analysis of the number of wetland classes included in the published papers with the Canada wetland layer (Canada post-2000 wetland extent $[90,91]$ ) superimposed onto the map.

\subsubsection{Geographical Distribution Based on Provinces/Territories}

Figure 10 schematically illustrates a breakdown of RS-based wetland mapping studies in Canada by provinces/territories. This figure shows the spatial pattern of wetland mapping in Canada using RS data. Lighter and darker green hues indicate the lower and higher number of studies, respectively. The white hue depicts no study in the corresponding province/territory of Canada. It should be noted that some papers cover multiple study areas (i.e., multiple provinces, ecoregions, and entire Canada), and as a result, each corresponding province/territory was included in the count, separately. In Figure 10, those papers categories in Canada-wide studies contain all provinces. Based on a Figure 10, a large proportion of the studies were developed and assessed for only a few provinces, especially ON and NL. The literature search revealed that more than $40 \%$ of the individual case studies were focused on areas in ON and NL (darker green hues in Figure 10). Figure 10 also illustrates that NT with a total of 12 papers and $A B$ and MB with 11 papers are other provinces where the wetlands were considered as the case studies. Very few published wetland research studies were identified from several provinces of Canada, including NU, YT, NB, NS, and BC. Overall, each of YT, NB, and NS accounted for two (less than $1.5 \%$ of published articles) studies.

As mentioned before, from all papers counted for all provinces in Figure 10, some papers contained multiple case studies and included several provinces. For example, ref. [92] expanded their study into more than one province, including MB and ON. On the other hand, ref. [54] applied their method on wetland mapping in AB and QC. As such, ref. [93] contained multiple case studies, including MB, NL, QC, and SK. 


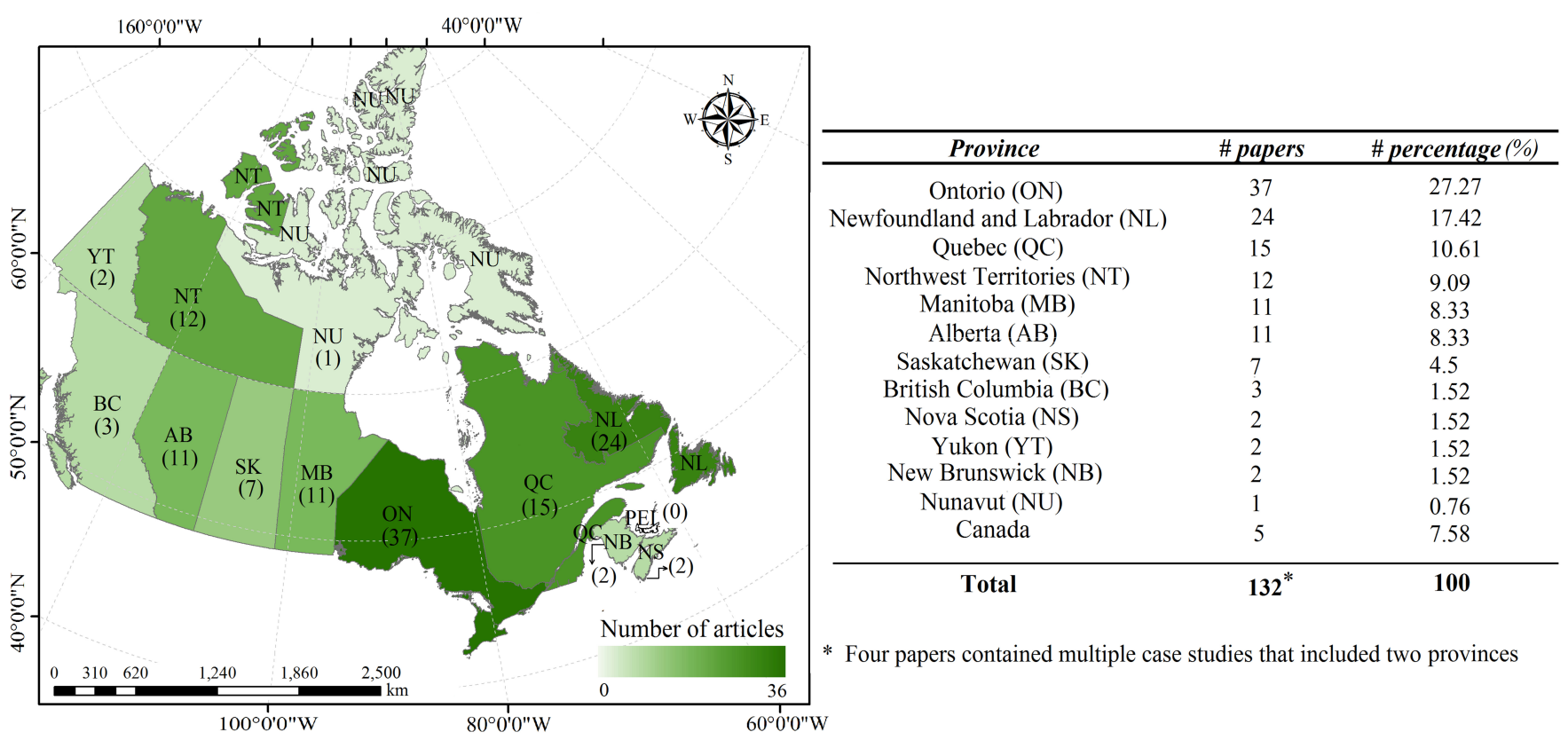

Figure 10. A choropleth map of Canada based on the number of RS-based wetland studies developed in various provinces. Lighter and darker green hues, respectively, indicate the low and high numbers of published papers.

\subsubsection{Geographical Distribution Based on the Extent of the Study Area}

We also examined the number of publications according to the extent of the study area (see Table 5). As such, the 128 wetland classification studies were divided into five categories based on the extent of the study area: very small (less than $100 \mathrm{~km}^{2}$ ), local (between $100 \mathrm{~km}^{2}$ and $3000 \mathrm{~km}^{2}$ ), regional (more than $3000 \mathrm{~km}^{2}$ and less than a provincial scale), provincial, and national (Canada-wide) scales.

Table 5. The number of publications focusing on various scales of the study area (small, local, regional, provincial, and national) in each Canadian province/territory.

\begin{tabular}{cccccccccccccccc}
\hline Scale & ON & NL & SK & NT & NS & MB & QC & AB & YT & NU & NB & BC & Canada & Total & Percentage \\
\hline Very small & 8 & 4 & 1 & 4 & 2 & 1 & 5 & 3 & - & - & 2 & 1 & & - & 32 \\
Local & 16 & 10 & 2 & 3 & - & 3 & 2 & 1 & - & - & - & 1 & - & 36 & $25 \%$ \\
Regional & 13 & 6 & 4 & 5 & - & 7 & 6 & 7 & 2 & 1 & - & 1 & - & 50 & $40 \%$ \\
Provincial & - & 4 & - & - & - & - & 1 & - & - & - & - & - & - & 5 & $4 \%$ \\
National & - & - & - & - & - & - & - & - & - & - & - & - & 5 & 5 & $4 \%$ \\
\hline
\end{tabular}

According to Table 5, the regional scale with a total of 50 papers, including 2 conference papers and 48 journal papers, had the highest number of published articles since 1976 . The local and very small scales with a total of 36 and 32 publications were, respectively, the second and third scales. Each of the provincial and national study areas accounted for five (about $4 \%$ of published articles) articles.

\subsection{Classification Methods}

Table A1 and Figure 11 summarize the information about wetland classification methods used in Canada. Different types of unsupervised and supervised classifiers have been used for wetland mapping in Canada. In total, 16 classification methods were employed across the 128 Canadian wetland classification studies. The RF [94-96], ML [97,98], Decision Tree (DT) [38,99-102], SVM [46-48], Multiple Classifier System (MCS) [11,103], Iterative Self-Organizing Data Analysis Technique (ISODATA) [104,105], CNN [21,27,54], k-Nearest Neighbors (k-NN) [106,107], and Artificial Neural Network (ANN) [30,108-110] were the most commonly used algorithms. The Linear Discriminant Analysis (LDA) [83,111,112], Fuzzy Rule-Based Classification Systems (FRBCSs) [11,19], Markov Random Fields (MRF)- 
based method $[113,114]$, k-means, and classification methods based on polarization target decomposition $[115,116]$ were used once or less than three times and, here, were categorized as the "Other" group.

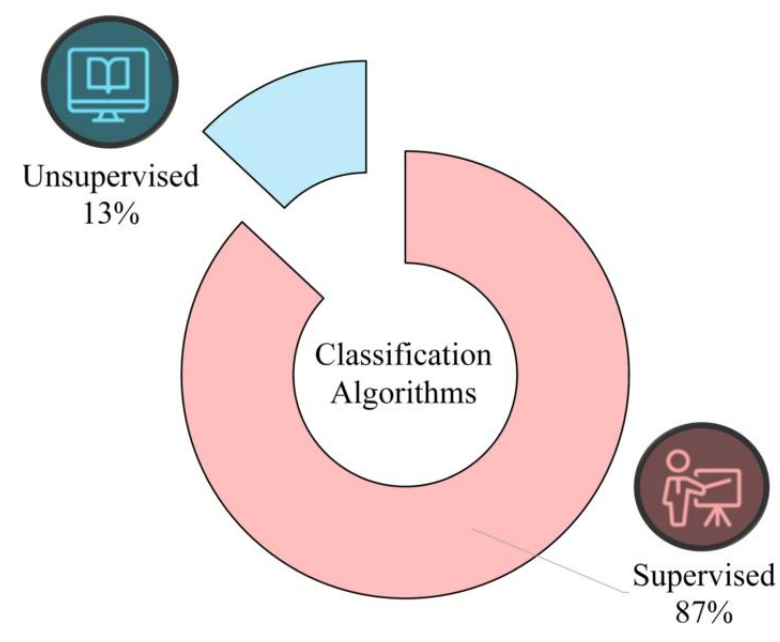

(a)

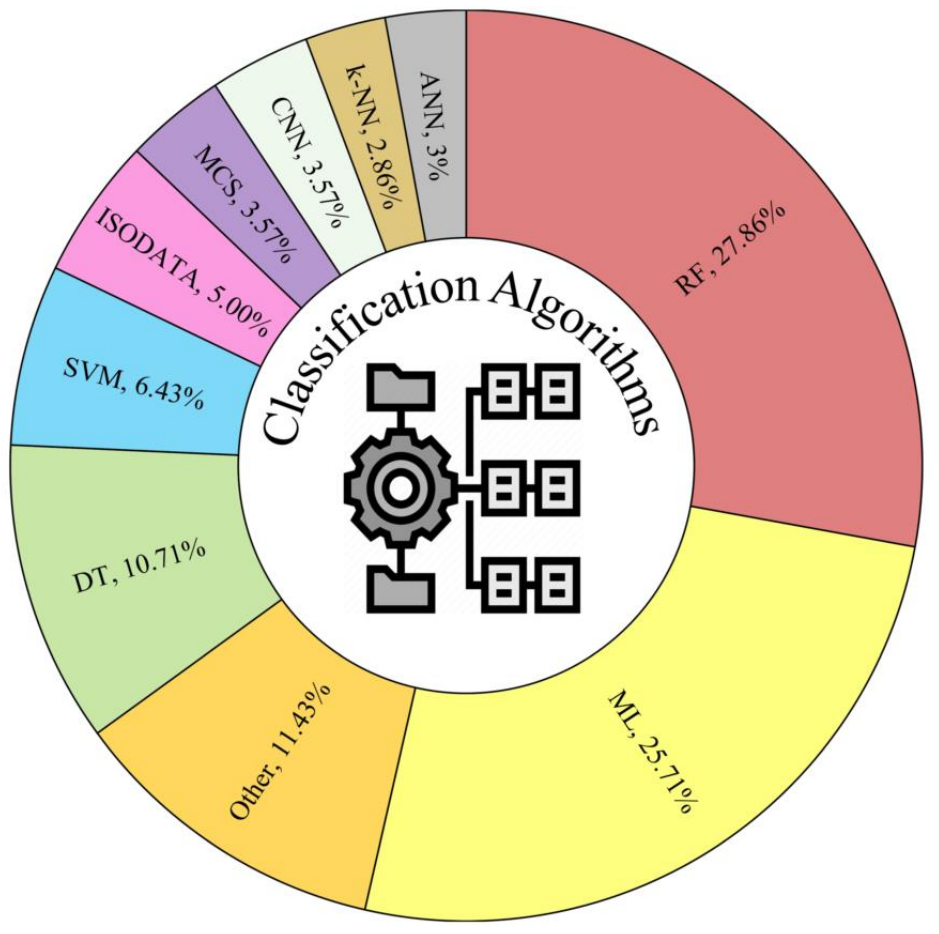

(b)

Figure 11. Percentage of the used machine learning (a) supervised and unsupervised classification approaches and (b) classifiers in wetland classification studies in Canada.

Figure 11 shows that researchers have tended to use supervised methods $(87 \%)$ in studies related to wetland classification in Canada rather than unsupervised approaches $(13 \%)$. This is mainly because the unsupervised methods typically deal with the untagged data, which require further analysis for mapping classes, and they usually have lower accuracies than supervised methods. Moreover, the RF classifier (27.86\%) was the most widely used algorithm, followed by ML (25.71\%) and DT (10.34\%) classifiers. The ANN $(2.86 \%), \mathrm{k}-\mathrm{NN}(2.86 \%), \mathrm{CNN}(3.57 \%)$, and MCS (3.57\%) were rarely employed in the studies. SVM and ISODATA were also used in more than five studies. Finally, $11.43 \%$ of the studies used other classifiers for Canadian wetland mapping.

The performance of the machine learning algorithms depends on several factors, including the complexity of the study area, type of RS data, quality of training samples, input features, classification algorithm, and tuning parameter settings [2]. Several metrics like overall accuracy, Kappa coefficient, producer's accuracy, and user's accuracy are typically used for classification performance evaluation. The wetland classification review studies rarely reported a complete confusion matrix to express wetland map errors (omission and commission errors), whereas they commonly stated the overall accuracy. Accordingly, the overall accuracy is here considered as a metric for comparing the accuracy of wetland mapping from different points of view.

The boxplots of the overall accuracy obtained from different algorithms are displayed in Figure 12 to evaluate their performance in wetland mapping in Canada. As shown in Figure 12 all classifiers had more than $80 \%$ median overall accuracy, except the "Other" group with the lowest median overall accuracy by $76 \%$. Among them, RF (88\%), CNN $(86.6 \%)$, and MCS (85.75\%) had higher median overall accuracies than the others. As expected, the "Other" group had the greatest range of overall accuracy results this group 
included dissimilar classification methods with different performances. ML, SVM, k-NN, DT, NN, and ISODATA with the median overall accuracies between $83 \%$ and $85 \%$ were the mid-range classifiers. The best $(97.67 \%)$ and worst $(62.40 \%)$ overall accuracies were achieved by RF [117] and Other [118] classifiers, respectively.

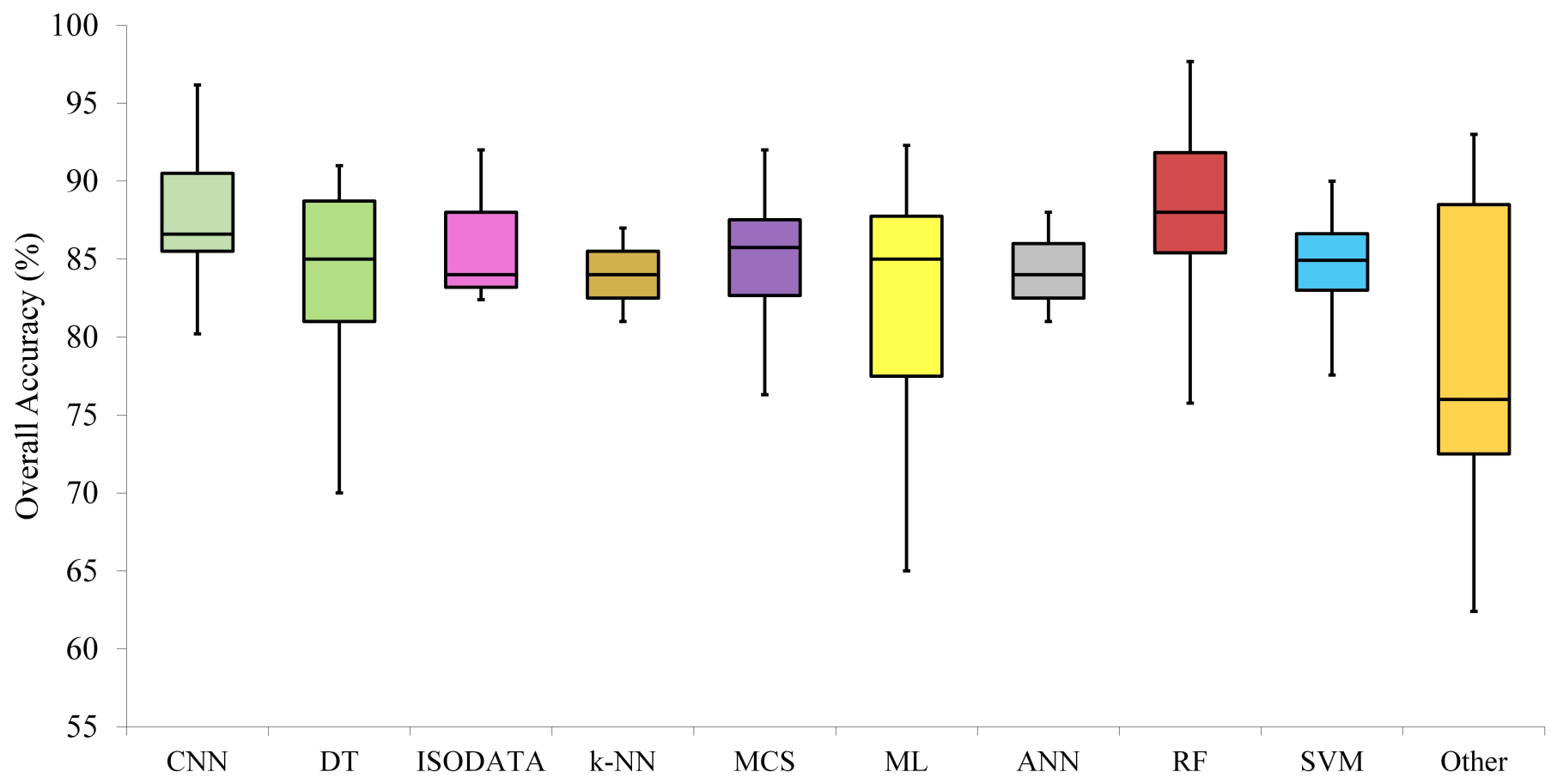

Figure 12. Boxplot distributions of the overall accuracies obtained by different classifiers used for wetland classification in Canada.

There are different wetland classification strategies. For instance, analysis of pixel information (i.e., pixel-based methods) has been emphasized in some studies. However, recent studies have frequently argued the higher potential of object-based methods for accurate wetland mapping [2]. The pixel-based methods utilize the spectral information of individual image pixels for classification [2,119]. In contrast, homogeneous information (e.g., geometrical or textural information) in images is considered through object-based methods $[17,119]$. The pixel-based classification methods were preferred to the object-based approaches in most of the wetland classification studies of Canada. This could be mainly due to the simplicity and comprehensibility of the pixel-based methods compared to object-based approaches. However, our investigations showed that object-based methods had been extensively utilized in recent wetland mapping studies $[7,68,73,103,120]$ due to their higher performance than pixel-based methods. The highest median overall accuracy $(87.2 \%)$ was achieved by the object-based methods indicating their higher potential in generating accurate wetland maps in Canada. Finally, the pixel-based methods involved a wider range of overall accuracies and had the lowest overall accuracy.

\subsection{RS Data Used in Wetland Studies of Canada}

RS datasets with diverse characteristics (e.g., different spatial, spectral, temporal, and radiometric resolutions) have been widely used for wetland mapping in Canada. In situ data and aerial imagery were the main data resources for wetland mapping in Canada before advancing spaceborne RS systems in the last four decades. Spaceborne RS systems provide a wide variety of datasets with different sensors and, these are great resources for wetland studies at different scales. Additionally, much of the spaceborne RS data is free [121], leading to high utilization in wetland studies. Moreover, with the advent of UAV technology in recent years, images with very high spatial and temporal resolutions have been provided for wetland studies. In general, with the availability of RS datasets acquired 
by diverse spaceborne/airborne sensors, researchers have more options to produce highly accurate wetland maps. For example, multi-spectral passive optical satellite/aerial images have been frequently employed for wetland studies due to their straightforward interpretation and rich spectral information. However, such datasets are susceptible to clouds, resulting in their inefficiency in the cloudy regions $[2,121]$. Moreover, due to their short wavelength, optical signals cannot penetrate into the vegetation canopy [18]. In contrast, SAR signals are less affected by climate conditions (e.g., clouds and rain) $[2,121,122]$. SAR signals also have a high capability to penetrate into vegetation canopies, making them more beneficial than optical sensors to obtain information about wetland characteristics like structure, surface roughness, and moisture content [2,18]. Furthermore, modern SAR missions (e.g., RADARSAT-2, RADARSAT Constellation Mission (RCM)) acquire data in any combination of linear (horizontal and vertical) or circular (right or left) polarizations, which are very helpful for mapping treed and herbaceous wetlands [18,123].

Many wetland studies have combined optical and SAR data to achieve more accurate results. Additionally, a combination of optical, SAR, and elevation data has been extensively used for wetland studies in Canada (see Figure 13) and has usually provided the highest classification accuracies. As shown in Figure 13, single optical data (95 studies) is the most common data for wetland studies in Canada. Moreover, SAR data (57 studies) or dual combinations of SAR and optical data (53 studies) were often used. Single elevation data type (22 studies) was mostly employed to produce different topographic features, which can be accommodated for 3D analysis of wetland species and wetland mapping. Dual combinations of optical and elevation data (19 studies), and triple combination of optical, SAR, and elevation data (24 studies) were moderately considered as input data for wetland studies in Canada. The combination of elevation data with SAR data were the least utilized data types (only six studies). A total of 12 studies employed other data types, such as data derived from satellite telemetry, radiometers, satellite transmitters and ground penetrating radar for wetland studies in Canada.

The studies typically conducted on RS data acquired by different platforms, such as airborne, spaceborne or a combination of them. Most of the studies $(\sim 67 \%)$ were based on the spaceborne RS systems. This is probably due to the high capability and cost-effectiveness of spaceborne RS datasets for wetland mapping and monitoring over large areas in Canada. The airborne RS datasets were used in 13\% of studies, where its combination with spaceborne RS datasets has been utilized in $20 \%$ of wetland studies. Recently, the use of Unmanned Aerial Vehicles (UAVs) equipped with RS sensors has become popular in wetland studies. In fact, the provided drone datasets could be a paradigm shift as they can be easily customized according to wetland studies specifications in contrast to spaceborne and piloted airborne RS datasets.

Figure 14 provides the frequently used optical and SAR sensors in wetland studies in Canada. Landsat, Sentinel-2, and RapidEye were the most common medium resolution spaceborne optical systems, while IKONOS and WorldView-2 were the most widely used high-resolution spaceborne optical sensors in wetland studies in Canada. Among them, Landsat 4/5 images were often employed in studies due to their affordable spatial/temporal resolutions and rich archive datasets. Moreover, ERS-1 and -2, Sentinel 1, and RADARSAT- 1 and -2 are the most popular C-band SAR systems, where ALOS- 1 and -2 and TRASAR-X were widely used L-band and X-band SAR system in RS-based wetland studies in Canada. RADARSAT-2 images were frequently employed for wetland studies among SAR sensors because it is a Canadian SAR system, and it provides full/dualpolarization data with suitable azimuth and slant range resolutions. Finally, Compact Airborne Spectrographic Imager (CASI) hyperspectral system was the most popular sensor among airborne sensors. 


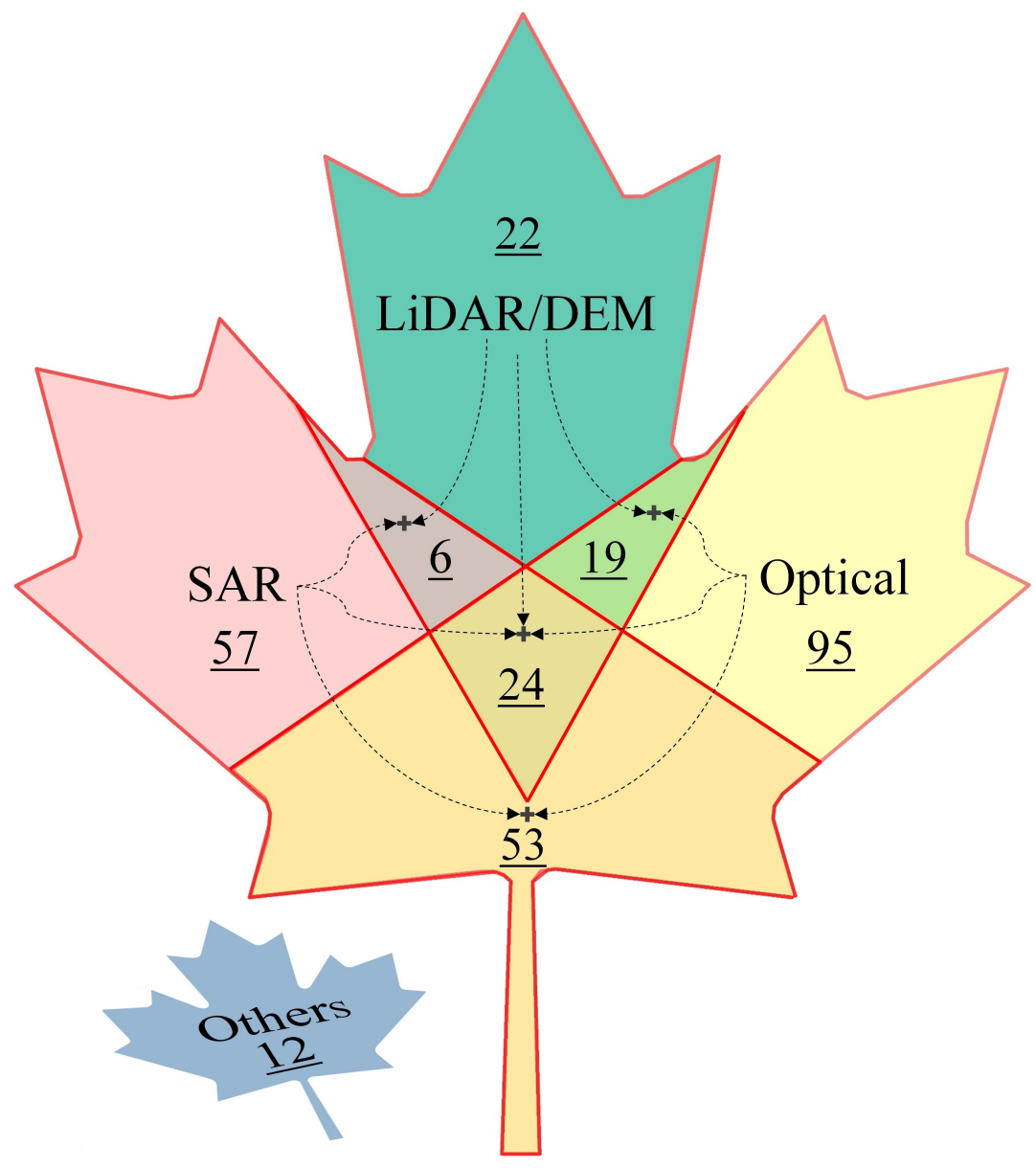

Figure 13. Data type(s) used in wetland studies in Canada.

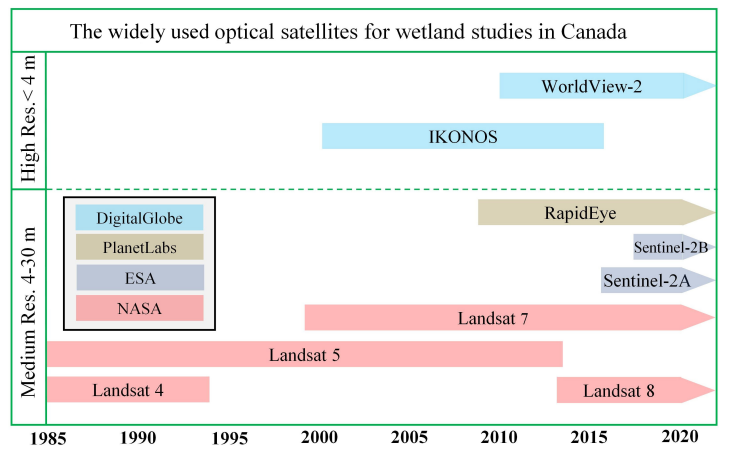

(a)

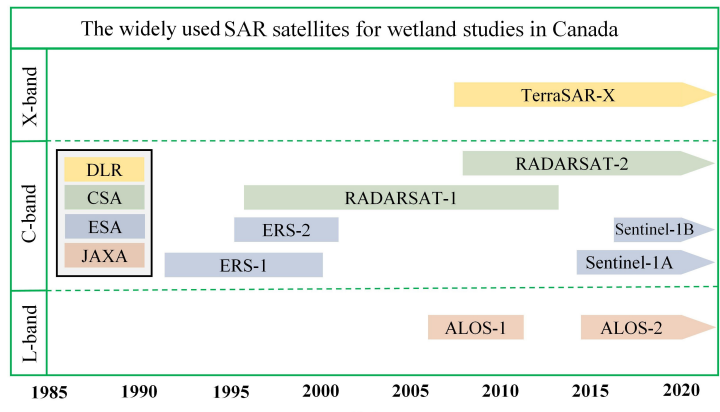

(b)

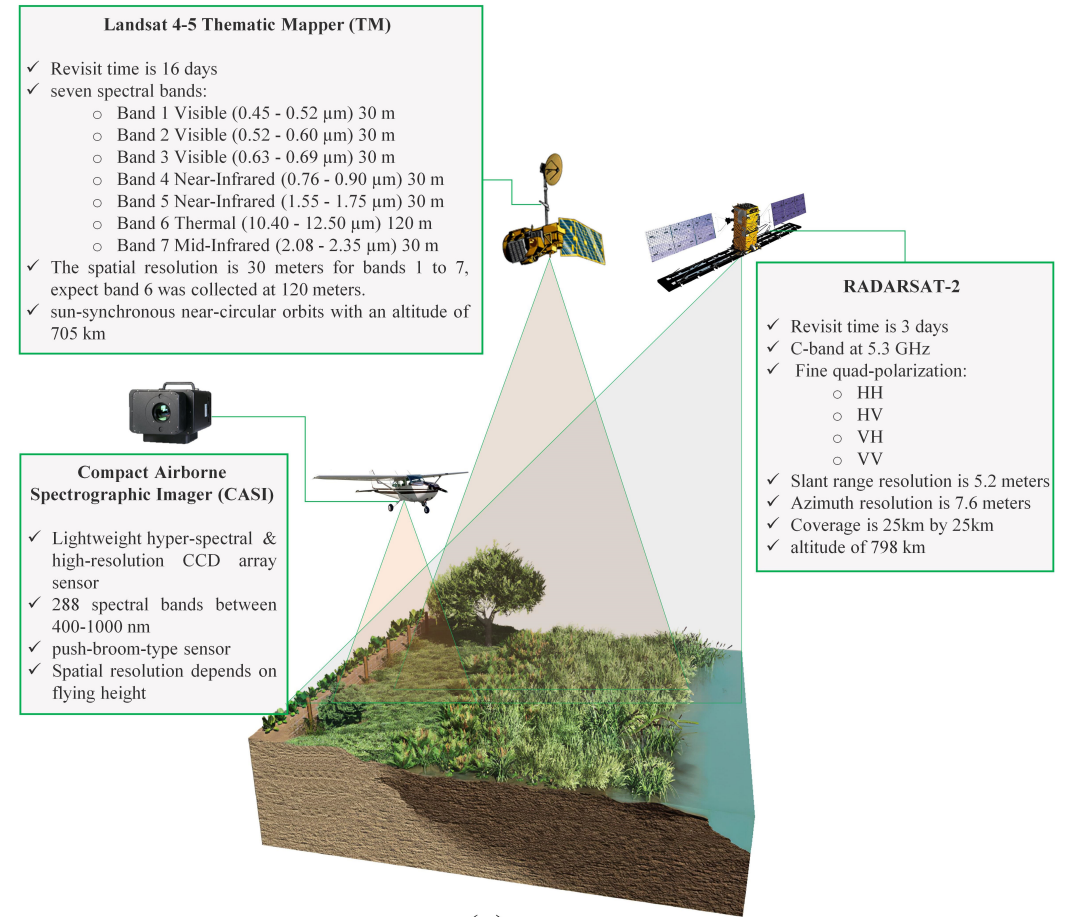

(c)

Figure 14. The frequently used (a) optical and (b) SAR satellites in wetland mapping in Canada and (c) the description of the most widely used RS systems. 
For a closer look, the overall accuracy reported in wetland classification studies for various data types is shown in Figure 15a. Based on Figure 15a, the median overall accuracy of the various data types and their combinations is more than $80 \%$. LiDAR/DEM data obtained the highest median overall accuracy $(92 \%)$, resulted from only 3 papers out of $22 \mathrm{LiDAR} / \mathrm{DEM}$ papers that reported accuracy. The lowest median overall accuracy $(82.4 \%)$ was achieved based on the SAR data type. However, a combination of SAR by another data type (e.g., optical or DEM) resulted in a better median overall accuracy. The median overall accuracy obtained by the optical data improved by combining with LiDAR/DEM data. Given the large number of studies conducted based on optical data, a wide range of overall accuracy (between $62.40 \%$ and $96.17 \%$ ) was observed by this data, which was. Finally, the best overall accuracy $(97.6 \%)$ was achieved by a triple combination of SAR, optical, and elevation data.

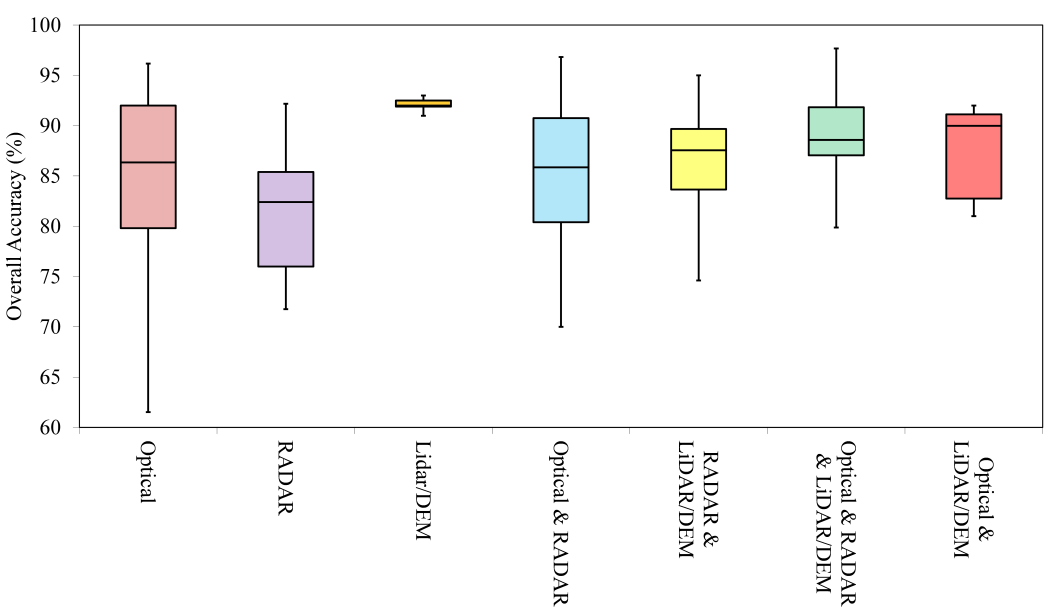

(a)

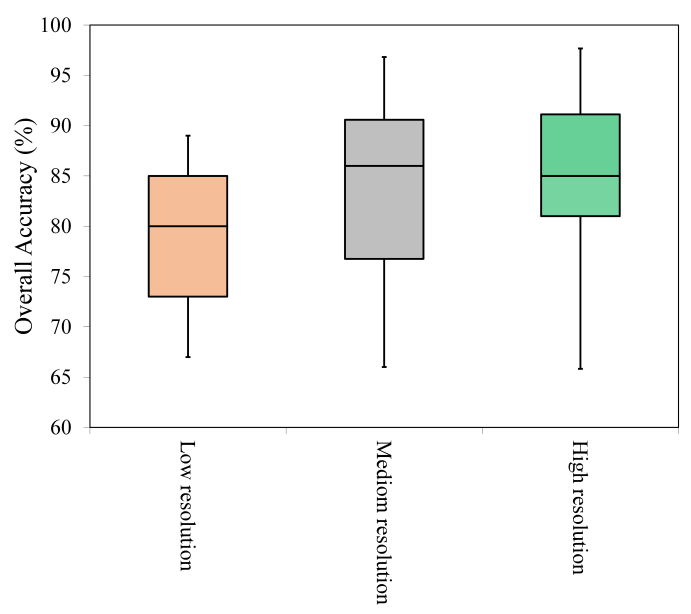

(b)

Figure 15. The overall accuracies reported in RS-based wetland classification studies in Canada (a) based on the different data types employed, and (b) based on the spatial resolution of the imagery.

Depending on the selected spatial resolution, wetland classification studies in Canada can also be categorized into three groups of high-resolution $(<4 \mathrm{~m})$, medium-resolution (4-30 m), and low-resolution (>30 m). Accordingly, the median overall accuracy achieved by reviewed papers using high, medium, and low spatial resolutions are illustrated in Figure 15b. The median of overall accuracy for all the spatial resolutions was more than $80 \%$. The best median overall accuracy was achieved for studies that used mediumresolution datasets for wetland mapping, closely followed by the high-resolution datasets. Moreover, a great range of overall accuracies was reported in various studies using medium resolution images. As expected, the weakest results belonged to studies that used low spatial resolution data. The highest $(97.67 \%)$ and lowest $(62.40 \%)$ overall accuracies were obtained using a high-resolution and medium resolution data, respectively.

The results showed that 18 types of RS systems were used more than three times in 128 wetland classification studies, which are depicted in Figure 16. Airborne platforms, followed by RADARSAT-2 and Landsat 4-5, were the most frequently utilized sensors in Canada for wetland mapping using RS data. Among the Landsat series, Landsat 7 was less used, which was probably due to the failure of the Scan Line Corrector (SLC) on its board. Sentinel-1/2, Advanced Spaceborne Thermal Emission and Reflection Radiometer (ASTER), Quickbird, ERS-1 and -2, and ALOS-2 were also among the sensors which were used in combination with other sensors. However, Quickbird, ASTER, GeoEye, and ERS-1 and -2 were the least common sensors with five or less uses. 


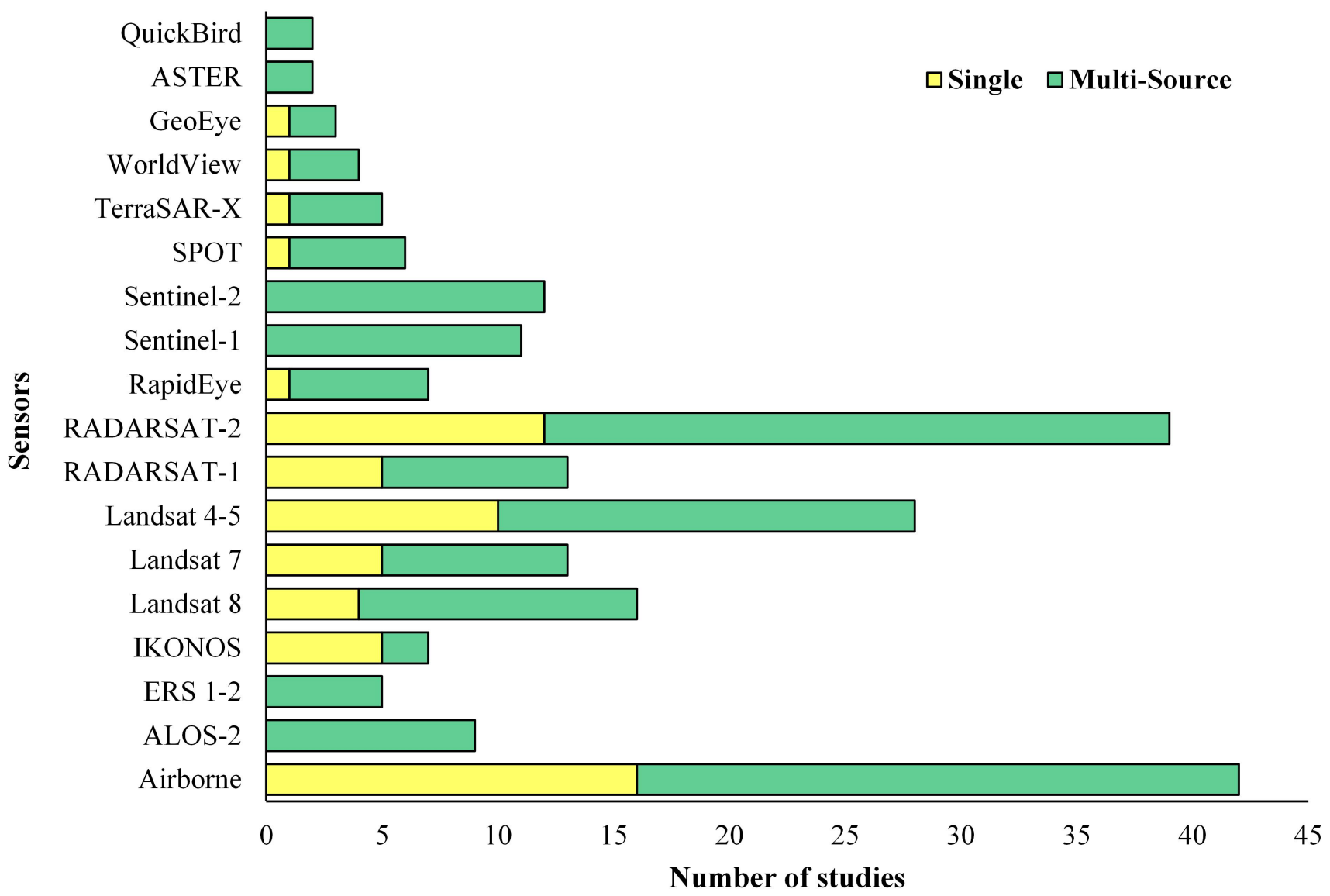

Figure 16. Frequency of different sensors used in RS-based wetland classification studies in Canada. Blue and red bards indicate if a single or multi-source data are used.

\subsection{Level of Classification Accuracy}

For a comprehensive investigation of the RS-based Canadian wetland studies, the reported overall accuracies were assessed and compared with various parameters, including the year of publication, the extent of the study area, and the number of classes considered in the classification method (see Figure 17). Figure 17a presents the histogram of the overall classification accuracies reported in 128 papers. Note that a wide range of studies (39 papers) did not report the overall accuracy of their classification methods (black column in Figure 17a). According to Figure $17 \mathrm{a}$, almost $80 \%$ (46 papers) of the studies have an overall accuracy between $84 \%$ and $93 \%$; while only 33 papers have an overall accuracy of less than $84 \%$ (between $62 \%$ and $83 \%$ ).

Based on Figure 17b, there is not a clear relationship between the overall classification accuracy and the year of publication. Two articles that were published in 1976-1995 have close overall accuracy to each other and the medium overall accuracy of $86 \%$. Two articles that were published in 1996-2000 have achieved different accuracies. The medium overall accuracy of those articles is $71 \%$. In another time-interval, there is a greater number of publications that have a wide range of overall accuracies between $63 \%$ and $96 \%$.

Based on Figure 17c, wetland classification methods applied to the provincial scales have the highest median overall accuracies, followed by very small and local study areas. On the other hand, the papers on national scales have the lowest median overall accuracies. Based on Figure 17d, more than $90 \%$ of the investigated articles used a few classes (between two and six). In these papers, the overall accuracies vary between $62 \%$ and $96 \%$. However, the median overall accuracies of these papers are $87 \%$ for $1-3$ classes and $86 \%$ for $4-6$ classes. In the case of 7-9 classes, the total number of papers decreases to four papers. The median overall accuracy of these four papers is $89 \%$. Moreover, those articles that considered a 
greater number of classes have higher median overall accuracies. We also found two papers that considered 10-18 classes for classifying wetlands and achieved the median overall accuracies of $94 \%$. As seen, a higher number of classes seem to be more accurate for the wetland classification method. We expect higher accuracies for a lower number of classes. Therefore, due to the significant discrepancy in the number of papers, it is impossible to provide a solid conclusion about the relationship between the overall accuracy of classification method and the number of classes.
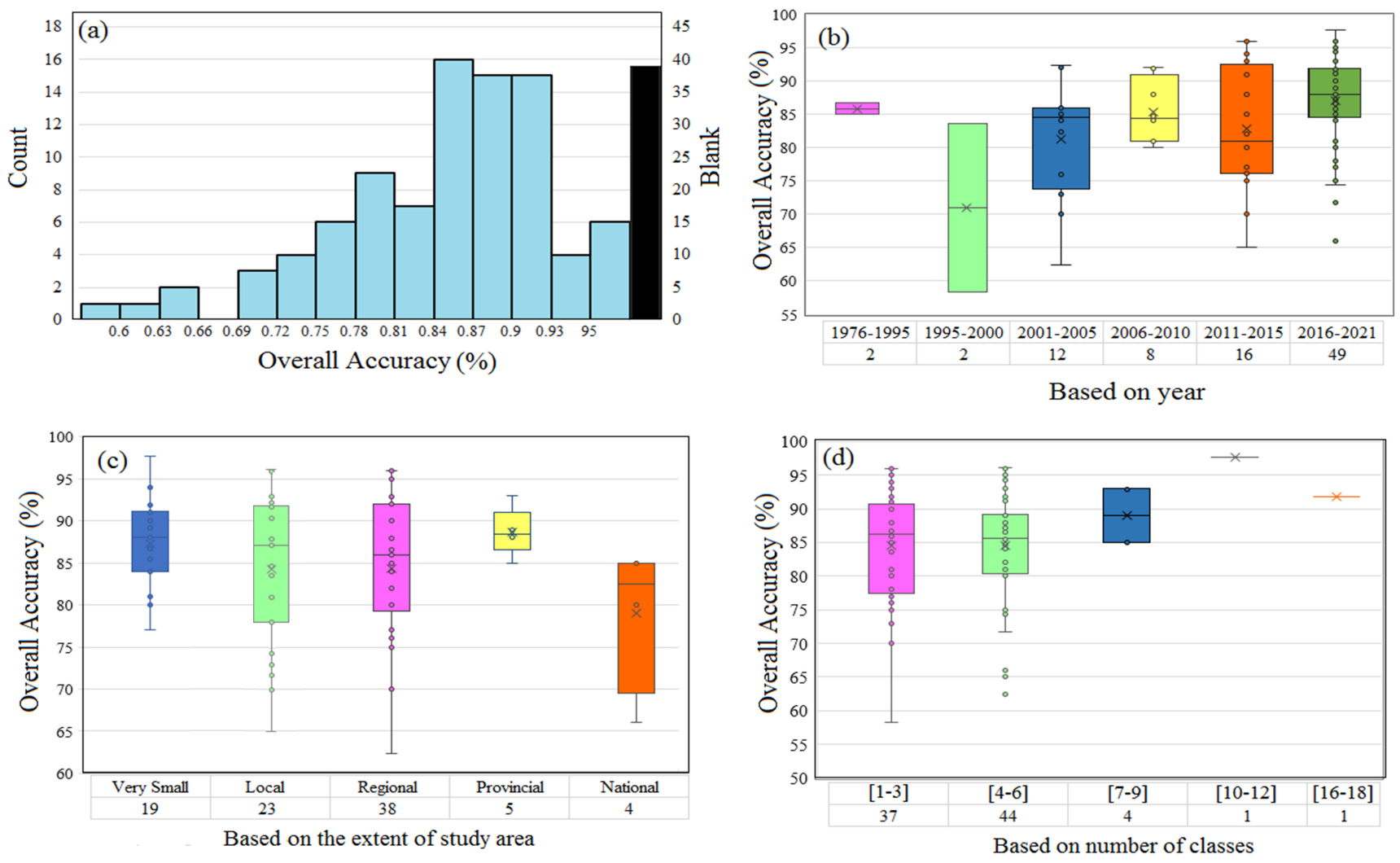

Figure 17. Overall accuracies reported in in RS-based wetland classification studies in Canada based on (a) the number of papers, (b) the year of publications, (c) the extent of study area, and (d) the number of classes considered in the classification method.

\section{Conclusions}

This review paper demonstrated the trends of RS-based wetlands studies in Canada by investigating 300 articles published from 1976 to 2020. In total, twelve subfields were summarized, including classification methods and their overall accuracies, RS datasets, journals, number of wetland classes, authors/co-authors contributions and affiliations, publications per year, geographical distributions, scale of the study areas, citation, and keywords. Eventually, a deeper meta-analysis was carried out to discuss the utilization of RS systems in these subfields over Canada particularly, which differentiates our survey from previous reviews. Consequently, this paper addresses the status of wetland studies in Canada using RS data and highlights opportunities and limitations for generating and updating Canadian wetland inventories, as well as classification protocols improvements. In summary, the meta-analysis of 300 wetland studies, 128 of which were related to wetland classification, presented the following outcomes:

- $\quad$ RS datasets have been increasingly used in the last four years, especially in NL. However, the largest number of studies has been conducted in ON over the past 40 years.

- Around half of the research studies have been implemented over the three provinces of $\mathrm{ON}, \mathrm{NL}$, and $\mathrm{QC}$, indicating the requirement for more efforts of wetlands mapping 
in other Canadian provinces to have a highly accurate and consistent country-wide wetland inventory.

- A total of $40 \%$ of the studies have been conducted over regional scales, and only five research papers have been published on a country scale. Although small-scale analysis can result in a classification with relatively higher accuracy, country-based classification can provide valuable details on the status and extent of wetlands for national and local administrative decision-makers.

- Novel deep learning methods and MCSs achieved more accurate maps in comparison to traditional techniques. RF, CNN, and MCS techniques provided the highest median overall accuracies.

- $\quad$ Pixel-based and supervised classification methods were the most popular techniques to map wetlands in Canada due to the simplicity and higher accuracies of these strategies compared to the object-based and unsupervised approaches, respectively. However, the median accuracy of object-based methods was more than pixel-based techniques and, therefore, they have been more frequently used in recent studies.

- Optical imagery and the combinations of optical and SAR datasets have been the most commonly used RS datasets to map wetlands in Canada. Availability, fulfilled archive, the high capability, and cost-effectiveness of optical and SAR imageries have attracted numerous focuses to utilize them. LiDAR/DEM data also resulted in the highest classification accuracies over small regions.

- Most (but not all) of the reviewed studies did not present the full confusion matrix and only reported the overall accuracy to evaluate the results which were easily affected by the stratification of samples between dry and wet classes. Additionally, accuracy statistics often depend on the different factors, such as the geographic extent of the study area, type of RS data, the degrees of wetland species, the quality of training and tests samples, and classification algorithm and its tuning parameter settings. Therefore, it would be required to increase the number of wetland studies that try to actually quantify wetland classification errors in different aspects.

- Approximately $30 \%$ of the studies considered the five CWCS wetland classes, and around $54 \%$ provides wetland maps using a lower number of classes.

- Frequencies of "SAR" and "RADARSAT (1/2)" displayed the importance of SAR data for wetland mapping in Canada because of the capability of SAR data to acquire images in any weather conditions considering the dominant cloudy and snowy climate of Canada.

This review paper highlights the efficiency of RS technology for accurate and continuous mapping of wetlands in Canada. The results can effectively help in selecting the optimum RS data and method for future wetland studies in Canada. In summary, implementation an object-based RF method along with a combination of optical and SAR images can be the optimum workflow to achieve a reasonable accuracy for wetland mapping at various scales in Canada.

Author Contributions: Conceptualization, S.M.M. and M.A.; methodology, S.M.M., A.G. and M.A.; investigation, S.M.M., A.M. and B.R.; writing—original draft preparation, S.M.M., A.M., B.R., F.M., A.G. and S.A.A.; writing—review and editing, all authors; visualization, S.M.M., A.M., B.R., F.M., A.G. and S.A.A.; supervision, M.A. and B.B. All authors have read and agreed to the published version of the manuscript.

Funding: This research received no external funding.

Data Availability Statement: The data presented in this study can be available on request from the author.

Acknowledgments: We would like to thank reviewers for their so-called insights.

Conflicts of Interest: The authors declare no conflict of interest. 


\section{Appendix A}

Table A1. Characteristics of the mostly used classifiers for wetland classification in Canada using RS data.

\begin{tabular}{|c|c|c|}
\hline Classifier & Description & Type \\
\hline ISODATA & $\begin{array}{l}\text { It is a modified version of } k \text {-means clustering in which } k \text { is allowed to } \\
\text { range over an interval. It includes the merging and splitting of } \\
\text { clusters during the iterative process. }\end{array}$ & Unsupervised \\
\hline ML & $\begin{array}{l}\text { It is a parametric algorithm based on Bayesian theory, assuming data } \\
\text { of each class follow the normal distribution. Accordingly, a pixel with } \\
\text { the maximum probability is assigned to the corresponding class. }\end{array}$ & Supervised/Unsupervised \\
\hline$k-\mathrm{NN}$ & $\begin{array}{l}\text { It is a non-parametric algorithm that classifies a pixel by a variety } \\
\text { vote of its neighbors, with the pixel being allocated to the class most } \\
\text { common among its } k \text { nearest neighbors. }\end{array}$ & Supervised \\
\hline SVM & $\begin{array}{l}\text { It is a type of non-parametric algorithm that defines a hyperplane/set } \\
\text { of hyperplanes in feature spaces used for maximizing the distance } \\
\text { between training samples of classes space and classify other pixels. }\end{array}$ & Supervised \\
\hline DT & $\begin{array}{l}\text { It is a non-parametric algorithm belonging to the category of } \\
\text { classification and regression trees (CART). It employs a tree structure } \\
\text { model of decisions for assigning a label to each pixel. }\end{array}$ & Supervised \\
\hline $\mathrm{RF}$ & $\begin{array}{l}\text { It is an improved version of DT, which includes an ensemble of } \\
\text { decision trees, in which each tree is formed by a subset of training } \\
\text { samples with replacements. }\end{array}$ & Supervised \\
\hline ANN & $\begin{array}{l}\text { It is a multi-stage classifier that typically includes the neurons } \\
\text { arranged in the input, hidden, and output layers. It is able to } \\
\text { learn a non-linear/linear function approximator for the } \\
\text { classification scheme. }\end{array}$ & Supervised \\
\hline $\mathrm{CNN}$ & $\begin{array}{l}\text { It is a class of multilayered neural networks/deep neural networks, } \\
\text { with a remarkable architecture to detect and classify complex features } \\
\text { in an image. }\end{array}$ & Supervised \\
\hline MCS & $\begin{array}{l}\text { It advantages from performances of dissimilar classifiers on a specific } \\
\text { LULC to achieve accurate classification of the image. }\end{array}$ & Supervised \\
\hline
\end{tabular}

Table A2. List of 300 studies and main characteristics.

\begin{tabular}{llllll}
\hline No. & First Author & Year & Region & Classification Method & Data \\
\hline 1 & Jeglum J. K. et al. [124] & 1975 & ON & - & Aerial \\
2 & Boissonneau A. N. et al. [125] & 1976 & ON & PB */Supervised/Other & Optical + Aerial \\
3 & Wedler E. et al. [126] & 1981 & ON & - & Radar \\
4 & Hughes F. M. et al. [127] & 1981 & AB & - & - \\
5 & Neraasen T. G. et al. [128] & 1981 & Canada & - & Optical \\
6 & Watson E. K. et al. [129] & 1981 & BC & - & Aerial \\
7 & Tomlins G. F. et al. [130] & 1981 & BC & - & Aerial \\
8 & Pala S. et al. [131] & 1982 & ON & - & Optical \\
9 & Lafrance P. et al. [132] & 1987 & QC & - & Optical \\
10 & Lafrance P. et al. [133] & 1988 & QC & - & Optical \\
11 & Peddle D. R. et al. [134] & 1989 & Canada & PB/Supervised/ML & - \\
12 & Kneppeck I.D. et al. [135] & 1989 & AB & - & Radar \\
13 & Drieman J. A. et al. [136] & 1989 & ON & - & Optical + Aerial \\
14 & Konrad S. R. et al. [137] & 1990 & Canada & PB/Unsupervised /ML & Optical \\
15 & Franklin S. E. et al. [138] & 1990 & NL & - & Optical \\
16 & Matthews S. B. et al. [139] & 1991 & NT & - & Aerial \\
17 & McNairn H. E. et al. [23] & 1993 & ON & PB/Supervised/ML & Aerial + Optical \\
18 & Franklin S. E. et al. [140] & 1994 & NL & - & Optical \\
19 & Cihlar J. et al. [141] & 1994 & MB & - & Aerial \\
20 & Franklin S. E. et al. [142] & 1994 & NL & - & Radar + Optical \\
21 & Yatabe S. M. et al. [50] & 1995 & ON & PB/Supervised/ML & Other = Aerial Video \\
22 & Strong L. L. [12] & 1995 & SK & - & Optical \\
23 & Bubier J. L. [143] & 1995 & MB & - & Optical + Aerial \\
24 & Pietroniro A. et al. [144] & 1996 & NT & PB/Supervised + & Unsupervised/Other \\
& & & & &
\end{tabular}


Table A2. Cont.

\begin{tabular}{|c|c|c|c|c|c|}
\hline No. & First Author & Year & Region & Classification Method & Data \\
\hline 25 & Hall F. G. et al. [145] & 1996 & Canada & - & Optical + Radar + Aerial \\
\hline 26 & Halsey L. [22] & 1997 & $\mathrm{MB}$ & - & Aerial \\
\hline 27 & Steyaert L. T. [93] & 1997 & $\mathrm{MB}, \mathrm{SK}$ & $\begin{array}{l}\text { PB/Unsupervised /ML + } \\
\text { Other = ISOCLASS }\end{array}$ & Optical + Aerial \\
\hline 28 & Hall F. G. et al. [106] & 1997 & SK & $\mathrm{PB} /$ Supervised/KNN & Optical \\
\hline 29 & Franklin S. E. et al. [146] & 1997 & NL & - & Aerial \\
\hline 30 & Collins N. et al. [147] & 1997 & NS & - & Aerial \\
\hline 31 & Wang J. et al. [25] & 1998 & $\mathrm{ON}$ & $\mathrm{PB} /$ Supervised/ML & Optical + Radar + Aerial \\
\hline 32 & Pietroniro A. et al. [148] & 1999 & $\mathrm{AB}$ & - & Optical + LiDAR/DEM \\
\hline 33 & Ghedira H. et al. [30] & 2000 & QC & $\mathrm{PB} /$ Supervised $/ \mathrm{DL}=\mathrm{NN}$ & Radar \\
\hline 34 & McLaren B. E. et al. [71] & 2001 & NL & $\mathrm{PB} /$ Supervised/Other & Radar + Optical + Aerial \\
\hline 35 & Baghdadi N. et al. [101] & 2001 & $\mathrm{ON}$ & PB/Supervised/DT & Radar \\
\hline 36 & Rapalee G. et al. [149] & 2001 & Canada & $\mathrm{PB} /$ Supervised/Other & $\begin{array}{l}\text { Optical + Aerial + } \\
\text { LiDAR/DEM }\end{array}$ \\
\hline 37 & Murphy M. A. [29] & 2001 & $\mathrm{ON}$ & $\begin{array}{l}\text { PB/Supervised/ISODATA + } \\
\text { Other }\end{array}$ & Radar \\
\hline 38 & Pietroniro A. et al. [150] & 2001 & $\mathrm{AB}$ & - & Optical + Radar \\
\hline 39 & Hall-Atkinson C et al. [151] & 2001 & NT & - & Radar + Optical + Aerial \\
\hline 40 & Sokol J. et al. [152] & 2001 & NL & - & Radar \\
\hline 41 & Dechka J. A. et al. [111] & 2002 & SK & $\begin{array}{l}\mathrm{PB} / \text { Supervised }+ \\
\text { Unsupervised/ISODATA + } \\
\text { Other }\end{array}$ & Optical + Aerial \\
\hline 42 & Gadallah F.L et al. [105] & 2002 & MB & PB/Supervised/ISODATA & Optical + Radar + Aerial \\
\hline 43 & Arzandeh S. et al. [97] & 2002 & $\mathrm{ON}$ & $\mathrm{PB} /$ Supervised/ML & Optical + Radar + Aerial \\
\hline 44 & Deslandes S. et al. [100] & 2002 & QC & PB/Supervised/DT & Optical + Radar + Aerial \\
\hline 45 & Jollineau M. et al. [153] & 2002 & $\mathrm{ON}$ & $\begin{array}{l}\text { PB/Supervised + } \\
\text { Unsupervised/ML }+ \text { K-Means }\end{array}$ & Optical \\
\hline 46 & Töyrä J. et al. [154] & 2002 & Canada & 1 & Optical + Radar \\
\hline 47 & Pietroniro A. et al. [155] & 2002 & $\mathrm{AB}$ & - & $\begin{array}{l}\text { Optical + RADAR + } \\
\text { LiDAR }\end{array}$ \\
\hline 48 & Poulin M. et al. [156] & 2002 & $\mathrm{QC}$ & - & Optical + Aerial \\
\hline 49 & Quinton W. L. et al. [157] & 2003 & NT & PB/Supervised/ML & Optical + Aerial \\
\hline 50 & Bernier M. et al. [158] & 2003 & QC & $\begin{array}{l}\mathrm{PB} / \text { Supervised } / \mathrm{ML}+\mathrm{DL}= \\
\mathrm{NN}\end{array}$ & Radar \\
\hline 51 & Thomas V. et al. [118] & 2003 & $\mathrm{MB}$ & $\mathrm{PB} /$ Supervised/ML & Other \\
\hline 52 & Jobin B. et al. [51] & 2003 & $\mathrm{QC}$ & PB/Supervised/ML & Optical + Aerial \\
\hline 53 & Arzandeh S. et al. [159] & 2003 & $\mathrm{ON}$ & PB/Supervised/ML & Optical + Radar + Aerial \\
\hline 54 & Havholm K. G. et al. [160] & 2003 & MB & - & Other \\
\hline 55 & Wessels J. et al. [161] & 2003 & Canada & - & Optical + Radar \\
\hline 56 & Bernier M. et al. [110] & 2003 & $\mathrm{QC}$ & - & Radar \\
\hline 57 & Racine M. J. et al. [162] & 2004 & $\overline{\mathrm{QC}}$ & $\mathrm{PB} /$ Supervised/ML & Radar \\
\hline 58 & Rosenqvist A. et al. [163] & 2004 & Canada & - & Radar \\
\hline 59 & Sokol J. et al. [164] & 2004 & Canada & - & Radar \\
\hline 60 & Li J. et al. [33] & 2005 & Canada & PB/Supervised/Other & Optical + Radar + LiDAR \\
\hline 61 & Tedford B. et al. [165] & 2005 & SK & - & Optical + Radar \\
\hline 62 & Grenier M. et al. [166] & 2005 & QC & - & Optical + Radar \\
\hline 63 & Cheng W. F. et al. [167] & 2005 & $\tilde{N L}$ & - & - \\
\hline 64 & Ju W. et al. [168] & 2005 & Canada & - & LiDAR/DEM \\
\hline 65 & Hudon C. et al. [169] & 2005 & $\mathrm{QC}$ & - & Optical + Aerial \\
\hline 66 & Niemann K.O. [170] & 2005 & Canada & - & Optical + Radar \\
\hline 67 & Smith K. B. et al. [171] & 2005 & Canada & - & Optical + Radar \\
\hline 68 & Li J. et al. [172] & 2005 & $\mathrm{ON}$ & - & Radar \\
\hline 69 & Töyrä J. et al. [173] & 2005 & $\mathrm{AB}$ & - & $\begin{array}{l}\text { Optical + Radar + } \\
\text { LiDAR/DEM + Aerial }\end{array}$ \\
\hline 70 & Mialon A. et al. [174] & 2005 & Canada & - & Optical +Radar \\
\hline 71 & Brown L. et al. [175] & 2006 & NU & - & Optical + Radar + Aerial \\
\hline 72 & Prowse T. D. et al. [176] & 2006 & $\begin{array}{l}\mathrm{AB}, \mathrm{BC}, \\
\mathrm{SK}\end{array}$ & - & Optical + Radar + Aerial \\
\hline
\end{tabular}


Table A2. Cont.

\begin{tabular}{|c|c|c|c|c|c|}
\hline No. & First Author & Year & Region & Classification Method & Data \\
\hline 73 & Peters D. L. et al. [177] & 2006 & $\mathrm{AB}, \mathrm{NT}$ & - & LiDAR/DEM \\
\hline 74 & Dillabaugh K. et al. [178] & 2006 & $\mathrm{ON}$ & - & Optical \\
\hline 75 & Grenier M. et al. [3] & 2007 & $\mathrm{QC}$ & OB */Supervised/Other & Optical + Radar \\
\hline 76 & Hogg A. R. et al. [35] & 2007 & $\widehat{\mathrm{ON}}$ & PB/Supervised/CART & LiDAR/DEM \\
\hline 77 & Li J. et al. [179] & 2007 & $\mathrm{ON}$ & $\mathrm{PB} /$ Supervised/ML & Optical + Radar \\
\hline 78 & Stevens C. E. et al. [180] & 2007 & $\mathrm{AB}$ & - & LiDAR/DEM \\
\hline 79 & Smith C. et al. [80] & 2007 & Canada & - & - \\
\hline 80 & Touzi R. et al. [88] & 2007 & $\mathrm{ON}$ & - & Radar \\
\hline 81 & Fournier R. A. et al. [181] & 2007 & Canada & - & $\begin{array}{l}\text { Optical + Radar + LiDAR } \\
+ \text { Aerial }\end{array}$ \\
\hline 82 & Touzi R. et al. [182] & 2007 & $\mathrm{ON}$ & - & Radar \\
\hline 83 & Gillanders S. N. et al. [104] & 2008 & $\mathrm{AB}$ & PB/Supervised/ISODATA & Optical \\
\hline 84 & Jollineau M. et al. [154] & 2008 & $\mathrm{ON}$ & $\mathrm{PB} /$ Supervised $/ \mathrm{ML}+$ Other & Optical \\
\hline 85 & Jollineau M. Y. et al. [32] & 2008 & $\mathrm{ON}$ & $\mathrm{PB} /$ Supervised /ML + Other & Optical \\
\hline 86 & Grenier M. et al. [3] & 2008 & $\mathrm{QC}$ & OB/Supervised/Other & Optical + Radar \\
\hline 87 & Dillabaugh K. A. et al. [109] & 2008 & $\mathrm{ON}$ & $\begin{array}{l}\mathrm{PB} / \text { Supervised } / \mathrm{ML}+\mathrm{DL}= \\
\mathrm{NN}\end{array}$ & Optical \\
\hline 88 & Hogg A. R. et al. [183] & 2008 & $\mathrm{ON}$ & - & Aerial + LiDAR/DEM \\
\hline 89 & Sass G. Z. et al. [184] & 2008 & $\mathrm{AB}$ & - & Radar \\
\hline 90 & Liu Y. et al. [185] & 2008 & $\mathrm{ON}$ & - & LiDAR/DEM \\
\hline 91 & Creed I. F. et al. [186] & 2008 & $\mathrm{AB}$ & - & Radar \\
\hline 92 & Touzi R. et al. [187] & 2008 & $\mathrm{ON}$ & - & Radar \\
\hline 93 & Kaheil Y. H. et al. [49] & 2009 & $\mathrm{AB}$ & PB/Supervised/SVM + Other & $\begin{array}{l}\text { Radar + Optical + LiDAR } \\
\text { + LiDAR/DEM }\end{array}$ \\
\hline 94 & Richardson M. C. et al. [36] & 2009 & $\mathrm{ON}$ & PB/Supervised/CART & LiDAR/DEM \\
\hline 95 & Dissanska M. et al. [108] & 2009 & QC & $\begin{array}{l}\text { OB } / \text { Supervised } / \mathrm{DL}=\mathrm{NN}+ \\
\text { Other }\end{array}$ & Optical + Aerial + DEM \\
\hline 96 & Harris A. et al. [188] & 2009 & $\mathrm{ON}$ & - & Aerial + Optical + Radar \\
\hline 97 & Rosa E. et al. [189] & 2009 & $\mathrm{QC}$ & - & Radar \\
\hline 98 & Raynolds M. K. et al. [190] & 2009 & NT & - & Optical + Other \\
\hline 99 & Pirie L. D. et al. [191] & 2009 & NT & - & Optical \\
\hline 100 & Spooner I. et al. [192] & 2009 & NS & - & Other \\
\hline 101 & Clark R. B. et al. [193] & 2009 & $\mathrm{AB}$ & - & Radar \\
\hline 102 & Fang X. et al. [194] & 2009 & SK & - & Aerial + LiDAR/DEM \\
\hline 103 & Touzi R. et al. [195] & 2009 & $\mathrm{ON}$ & - & Radar \\
\hline 104 & Touzi R. et al. [196] & 2009 & $\mathrm{ON}$ & - & Radar \\
\hline 105 & Collin A. et al. [37] & 2010 & QC & PB/Supervised/ML & LiDAR \\
\hline 106 & Andrea J. M. et al. [197] & 2010 & $\widehat{\mathrm{ON}}$ & - & Optical \\
\hline 107 & Soverel N.O. et al. [198] & 2010 & Canada & - & Optical \\
\hline 108 & Levrel G. et al. [199] & 2010 & $\mathrm{QC}$ & - & Radar \\
\hline 109 & Sannel A. B. K. et al. [200] & 2010 & Canada & - & Optical + Aerial \\
\hline 110 & Neta T. et al. T. [201] & 2010 & $\mathrm{MB}, \mathrm{ON}$ & - & Optical \\
\hline 111 & Midwood J. D. et al. [202] & 2010 & $\mathrm{ON}$ & - & Optical \\
\hline 112 & Touzi R. et 1. [203] & 2010 & $\mathrm{QC}$ & - & Radar \\
\hline 113 & Fang X. et al. [204] & 2010 & SK & - & Optical + Lidar/DEM \\
\hline 114 & Brisco B. et al. [205] & 2011 & $\mathrm{MB}$ & $\mathrm{PB} /$ Supervised /ML + Other & Radar + LiDAR/DEM \\
\hline 115 & Crowell N. et al. [206] & 2011 & NS & - & LiDAR/DEM \\
\hline 116 & Quinton W. L. et al. [207] & 2011 & NT & $\mathrm{PB} /$ Supervised/Other & $\begin{array}{l}\text { Optical + Aerial + } \\
\text { LiDAR/DEM }\end{array}$ \\
\hline 117 & Rokitnicki-Wojcik D. et al. [208] & 2011 & $\mathrm{ON}$ & OB/Supervised/Other + DT & Optical \\
\hline 118 & Muskett R. R. et al. [209] & 2011 & $\mathrm{YT}$ & - & Optical + Other \\
\hline 119 & Chen B. et al. [210] & 2011 & Canada & - & Optical \\
\hline 120 & Neta T. et al. [211] & 2011 & $\mathrm{ON}, \mathrm{MB}$ & - & Optical + Aerial \\
\hline 121 & Hogan D. et al. [212] & 2011 & $\begin{array}{l}\mathrm{AB}, \mathrm{BC}, \\
\mathrm{YT}\end{array}$ & - & Optical + Aerial \\
\hline 122 & Shook K. R. et al. [213] & 2011 & SK & - & LiDAR/DEM \\
\hline 123 & Watchorn K. E. et al. [92] & 2012 & $\mathrm{MB}, \mathrm{ON}$ & - & \\
\hline 124 & Fraser S. et al. [214] & 2012 & $\mathrm{MB}$ & - & Optical + Other \\
\hline
\end{tabular}


Table A2. Cont.

\begin{tabular}{|c|c|c|c|c|c|}
\hline No. & First Author & Year & Region & Classification Method & Data \\
\hline 125 & Guo X. et al. [215] & 2012 & SK & $\begin{array}{l}\mathrm{PB}+\mathrm{OB} / \text { Supervised } / \mathrm{ML}+ \\
\mathrm{KNN}\end{array}$ & Radar \\
\hline 126 & Allard M. et al. [11] & 2012 & QC & $\begin{array}{l}\text { OB/Supervised/Multiple } \\
\text { classifier }\end{array}$ & Optical \\
\hline 127 & Dribault Y. et al. [19] & 2012 & QC & OB/Supervised/Other & Optical + Aerial \\
\hline 128 & Barker R. et al. [216] & 2012 & QC & - & Aerial \\
\hline 129 & Kaya S. et al. [217] & 2012 & Canada & - & Radar \\
\hline 130 & Pivot F. C [218] & 2012 & $\mathrm{MB}$ & - & Radar \\
\hline 131 & Midwood J. D. et al. [219] & 2012 & $\mathrm{ON}$ & - & Optical \\
\hline 132 & Gala T. S. et al. [220] & 2012 & SK & - & $\begin{array}{l}\text { Optical + Radar + } \\
\text { LiDAR/DEM }\end{array}$ \\
\hline 133 & Brisco B. et al. [48] & 2013 & MB & $\mathrm{PB} /$ Supervised/SVM + ML & Radar + Aerial \\
\hline 134 & Chen W. et al. [221] & 2013 & MB & PB/Supervised/Other & $\begin{array}{l}\text { Optical + Radar + } \\
\text { LiDAR/DEM }\end{array}$ \\
\hline 135 & Lantz N. J. et al. [63] & 2013 & $\mathrm{ON}$ & $\begin{array}{l}\text { OB + PB/Supervised/NN + } \\
\text { ML }\end{array}$ & Optical \\
\hline 136 & Millard K. et al. [42] & 2013 & $\mathrm{ON}$ & $\mathrm{PB} /$ Supervised/RF & Radar + LiDAR \\
\hline 137 & Kokelj, S. V. et al. [87] & 2013 & YT, NT & - & LiDAR \\
\hline 138 & Doiron M. et al. [222] & 2013 & NU & - & Optical \\
\hline 139 & McClymont A. F et al. [223] & 2013 & NT & - & Other \\
\hline 140 & Lapointe J. et al. [224] & 2013 & QC & - & Other \\
\hline 141 & Huschle G. et al. [225] & 2013 & $\begin{array}{l}\text { SK, MB, } \\
\text { ON }\end{array}$ & - & Other \\
\hline 142 & Mattar K. E. [226] & 2013 & $\mathrm{ON}$ & - & Radar \\
\hline 143 & Jacome A. et al. [227] & 2013 & $\mathrm{QC}$ & - & Radar \\
\hline 144 & Chasmer L. et al. [102] & 2014 & NT & $\mathrm{PB} /$ Supervised/DT + Other & Optical + LiDAR/DEM \\
\hline 145 & Banks S. N. et al. [228] & 2014 & NT & $\begin{array}{l}\mathrm{PB} / \text { Supervised + } \\
\text { Unsupervised/ML }\end{array}$ & Optical + Radar + UAV \\
\hline 146 & Banks S. N. et al. [229] & 2014 & NT & $\begin{array}{l}\mathrm{PB} / \text { Supervised }+ \\
\text { Unsupervised/Other }\end{array}$ & Radar + UAV \\
\hline 147 & Touzi R. et al. [115] & 2014 & $\mathrm{AB}$ & PB/Supervised/Other & Radar \\
\hline 148 & Pastick N. J. et al. [99] & 2014 & $\mathrm{YT}$ & PB/Supervised/DT & Optical \\
\hline 149 & Sutherland G. et al. [38] & 2014 & $\mathrm{AB}$ & PB/Supervised/DT & LiDAR + LiDAR/DEM \\
\hline 150 & Ullmann T. et al. [52] & 2014 & NT & $\begin{array}{l}\mathrm{PB} / \text { Supervised + } \\
\text { Unsupervised/ML }\end{array}$ & Optical + Radar \\
\hline 151 & Dech J. P. et al. [95] & 2014 & $\mathrm{ON}$ & - & LiDAR/DEM \\
\hline 152 & Gosselin G. et al. [116] & 2014 & QC & OB/Supervised/ML + Other & Optical + Radar \\
\hline 153 & Ahern F. J. et al. [230] & 2014 & $\widehat{\mathrm{ON}}$ & PB/Supervised/Other & Radar \\
\hline 154 & Armenakis C. et al. [231] & 2014 & $\mathrm{BC}, \mathrm{NS}$ & - & - \\
\hline 155 & Connon R. F. et al. [89] & 2014 & NT & - & Optical + Aerial \\
\hline 156 & Ely C. R. et al. [232] & 2014 & Canada & - & Radar \\
\hline 157 & Chabot D. et al. [233] & 2014 & QC & - & UAS \\
\hline 158 & Cable J. W. et al. [234] & 2014 & $\widehat{\mathrm{ON}}$ & - & Radar \\
\hline 159 & Nelson T. A. et al. [235] & 2014 & Canada & - & Optical \\
\hline 160 & Clare S. et al. [236] & 2014 & $\mathrm{AB}$ & - & - \\
\hline 161 & Mui A. et al. [107] & 2015 & Canada & OB/Supervised/KNN & Optical + LiDAR/DEM \\
\hline 162 & Dabboor M. et al. [16] & 2015 & $\mathrm{MB}$ & PB/Unsupervised/Other & Radar \\
\hline 163 & Bourgeau-Chavez L. et al. [237] & 2015 & $\mathrm{ON}$ & $\begin{array}{l}\mathrm{PB}+\mathrm{OB} / \text { Supervised } / \mathrm{ML}+ \\
\text { Other }\end{array}$ & Optical + Radar + Aerial \\
\hline 164 & Sizo A. et al. [114] & 2015 & SK & PB/Unsupervised/Other & Optical \\
\hline 165 & Umbanhowar Jr C. E et al. [238] & 2015 & $\mathrm{MB}$ & PB/Unsupervised/ISODATA & $\begin{array}{l}\text { Optical + Aerial + } \\
\text { LiDAR/DEM }\end{array}$ \\
\hline 166 & Sagin J. et al. [239] & 2015 & SK & - & Optical \\
\hline 167 & Dingle R. L. et al. [240] & 2015 & $\mathrm{ON}$ & - & Optical \\
\hline 168 & Kalacska M. et al. [241] & 2015 & $\mathrm{ON}$ & $\mathrm{PB} /$ Supervised/Other & Other \\
\hline 169 & Kotchi S. O. et al. [242] & 2015 & $\mathrm{QC}$ & - & Optical + Radar \\
\hline 170 & Tougas-Tellier M. A. et al. [243] & 2015 & $\widehat{\mathrm{QC}}$ & - & Optical + Aerial \\
\hline 171 & Messmer D. J. et al. [244] & 2015 & ON & - & Optical + UAV + Aerial \\
\hline
\end{tabular}


Table A2. Cont.

\begin{tabular}{|c|c|c|c|c|c|}
\hline No. & First Author & Year & Region & Classification Method & Data \\
\hline 172 & Brisco B. et al. [245] & 2015 & $\mathrm{ON}$ & - & Radar \\
\hline 173 & Muster S. et al. [246] & 2015 & NU & - & Optical \\
\hline 174 & Jiao X. et al. [247] & 2015 & $\mathrm{AB}$ & - & Radar \\
\hline 175 & Li-Chee-Ming J. et al. [248] & 2015 & $\mathrm{AB}$ & - & Radar + UAV \\
\hline 176 & Thompson S. D. et al. [249] & 2016 & $\mathrm{BC}$ & PB/Unsupervised/Other & Optical + LiDAR + Aerial \\
\hline 177 & Braverman M. et al. [34] & 2016 & NT & - & LiDAR/DED \\
\hline 178 & Marcaccio J. V.et al. [250] & 2016 & $\mathrm{ON}$ & OB/Supervised/ML + Other & $\begin{array}{l}\text { Optical + Radar + Aerial + } \\
\text { UAV }\end{array}$ \\
\hline 179 & Ou C. et al. [56] & 2016 & $\mathrm{ON}$ & PB/Supervised/RF & $\begin{array}{l}\text { Optical + Radar + } \\
\text { LiDAR/DEM }\end{array}$ \\
\hline 180 & Lara M. J. et al. [98] & 2016 & NT & PB/Supervised/ML & Optical + Radar + Aerial \\
\hline 181 & Mohammadimanesh F. et al. [112] & 2016 & NL & $\mathrm{PB} /$ Supervised/Other & Radar \\
\hline 182 & Chasmer L. et al. [251] & 2016 & $\mathrm{AB}$ & - & LiDAR + Aerial \\
\hline 183 & Spence C. et al. [252] & 2016 & SK & - & $\begin{array}{l}\text { Optical + UAV + } \\
\text { LiDAR/DEM }\end{array}$ \\
\hline 184 & Shinneman A. L. C. et al. [253] & 2016 & $\mathrm{MB}$ & - & Optical \\
\hline 185 & Finger T. A. et al. [254] & 2016 & $\mathrm{ON}$ & - & Other \\
\hline 186 & Miller S. M. et al. [255] & 2016 & Canada & - & Optical + Aerial \\
\hline 187 & Kross A. et al. [256] & 2016 & $\mathrm{ON}, \mathrm{AB}$ & - & Optical \\
\hline 188 & Shodimu O. et al. [257] & 2016 & NB & - & Optical \\
\hline 189 & Schmitt A. et al. [258] & 2016 & Canada & - & Radar \\
\hline 190 & Emmerton C. A. et al. [259] & 2016 & NU & - & Optical \\
\hline 191 & Serran J. N. et al. [260] & 2016 & $\mathrm{AB}$ & - & Aerial + LiDAR/DEM \\
\hline 192 & Bolanos S. et al. [261] & 2016 & $\mathrm{AB}, \mathrm{SK}$ & - & Optical + Radar \\
\hline 193 & Morsy S. et al. [262] & 2016 & ON & - & LiDAR \\
\hline 194 & van der Kamp G. et al. [263] & 2016 & Canada & - & - \\
\hline 195 & Sizo A. et al. [264] & 2016 & SK & - & Optical \\
\hline 196 & Ullmann T. et al. [265] & 2016 & NT & - & Radar \\
\hline 197 & Mahdianpari M. et al. [43] & 2017 & NL & OB/Supervised/RF & Radar \\
\hline 198 & Banks S. et al. [58] & 2017 & NU & PB/Supervised/RF & $\begin{array}{l}\text { Radar + Optical + } \\
\text { LiDAR/DEM + UAV }\end{array}$ \\
\hline 199 & Merchant M.A. et al. [47] & 2017 & NT & PB/Supervised/SVM & Radar \\
\hline 200 & Amani M. et al. [266] & 2017 & NL & OB/Supervised/RF & Optical \\
\hline 201 & Hird J. N. et al. [40] & 2017 & $\mathrm{AB}$ & PB/Supervised/ML & $\begin{array}{l}\text { Optical + Radar + Aerial + } \\
\text { LiDAR/DEM }\end{array}$ \\
\hline 202 & Chen Z. et al. [57] & 2017 & NT & $\begin{array}{l}\mathrm{PB}+\mathrm{OB} / \text { Supervised } / \mathrm{RF}+ \\
\mathrm{ML}\end{array}$ & Optical \\
\hline 203 & Bourgeau-Chavez L. L. et al. [55] & 2017 & $\mathrm{AB}$ & $\mathrm{PB}+\mathrm{OB} /$ Supervised / RF & Optical + Radar \\
\hline 204 & White L. et al. [60] & 2017 & $\mathrm{ON}$ & PB/Supervised/RF & $\begin{array}{l}\text { Optical + Radar + } \\
\text { LiDAR/DEM }\end{array}$ \\
\hline 205 & Mahdavi S. et al. [72] & 2017 & NL & $\mathrm{PB}+\mathrm{OB} /$ Supervised $/ \mathrm{RF}$ & Optical + Radar + Aerial \\
\hline 206 & Franklin S. E. et al. [61] & 2017 & $\mathrm{ON}$ & OB/Supervised/RF & $\begin{array}{l}\text { Optical + Radar + Aerial + } \\
\text { LiDAR/DEM }\end{array}$ \\
\hline 207 & Mahdianpari M. et al. [44] & 2017 & NL & $\mathrm{OB} /$ Supervised $/ \mathrm{RF}+$ Other & Optical + Radar \\
\hline 208 & Amani M. et al. [39] & 2017 & NL & OB/Supervised/RF & Optical + Radar \\
\hline 209 & Mahdianpari M. et al. [267] & 2017 & NL & PB/Supervised/RF & Radar + Aerial \\
\hline 210 & Amani M. et al. [7] & 2017 & NL & OB/Supervised/RF & Optical + Radar + Aerial \\
\hline 211 & Amani M. et al. [73] & 2017 & NL & $\begin{array}{l}\mathrm{PB}+\mathrm{OB} / \text { Supervised } / \mathrm{KNN}+ \\
\mathrm{ML}+\mathrm{SVM}+\mathrm{CART}+\mathrm{RF}\end{array}$ & Optical + Aerial \\
\hline 212 & Lovitt J. et al. [268] & 2017 & $\mathrm{AB}$ & - & UAV + LiDAR \\
\hline 213 & Kim S. et al. [269] & 2017 & Canada & - & Optical + Radar \\
\hline 214 & Mohammadimanesh F. et al. [270] & 2017 & NL & - & Radar + LiDAR/DEM \\
\hline 215 & Dabboor M. et al. [271] & 2017 & $\mathrm{ON}$ & - & Radar \\
\hline 216 & Chabot D. et al. [272] & 2017 & $\mathrm{ON}$ & - & UAS \\
\hline 217 & Perreault N. et al. [273] & 2017 & $\mathrm{NU}$ & - & Optical \\
\hline
\end{tabular}


Table A2. Cont.

\begin{tabular}{|c|c|c|c|c|c|}
\hline No. & First Author & Year & Region & Classification Method & Data \\
\hline 218 & Ullmann T. et al. [274] & 2017 & NT & - & Radar \\
\hline 219 & Brisco et al. [275] & 2017 & Canada & - & - \\
\hline 220 & Mahdavi S. et al. [2] & 2018 & Canada & - & - \\
\hline 221 & Amani M. et al. [103] & 2018 & NL & OB/Supervised/Other & Optical + Radar \\
\hline 222 & Wulder, M. A. et al. [90] & 2018 & Canada & $\mathrm{PB} /$ Supervised / RF + Other & Optical \\
\hline 223 & Mohammadimanesh F. et al. [276] & 2018 & NL & OB/Supervised/RF + SVM & Radar \\
\hline 224 & Chabot D. et al. [53] & 2018 & $\mathrm{ON}$ & OB/Supervised/ML & UAV \\
\hline 225 & Paul S. S. et al. [113] & 2018 & Canada & OB/Supervised/ML + Other & Optical \\
\hline 226 & D'Acunha B. et al. [277] & 2018 & $\mathrm{BC}$ & - & Optical \\
\hline 227 & Arroyo-Mora J. P. et al. [20] & 2018 & $\mathrm{ON}$ & - & Optical + Other \\
\hline 228 & Mahdianpari M. et al. [83] & 2018 & NL & PB/Supervised/RF & Radar \\
\hline 229 & Ahern F. et al. [278] & 2018 & $\mathrm{ON}$ & $\mathrm{PB} /$ Supervised/Other & Radar \\
\hline 230 & Jahncke R. et al. [94] & 2018 & NS & $\mathrm{PB} /$ Supervised/RF & $\begin{array}{l}\text { Optical + Radar + LiDAR } \\
+ \text { Aerial }\end{array}$ \\
\hline 231 & Mohammadimanesh F. et al. [96] & 2018 & NL & OB/Supervised/RF & Radar \\
\hline 232 & Amani M. et al. [39] & 2018 & NL & $\mathrm{OB} /$ Supervised/RF & Optical \\
\hline 233 & Mahdianpari M. et al. [27] & 2018 & NL & $\begin{array}{l}\mathrm{PB} / \text { Supervised/DL + SVM + } \\
\mathrm{RF}\end{array}$ & Optical \\
\hline 234 & Franklin S. E. et al. [62] & 2018 & $\mathrm{ON}$ & $\begin{array}{l}\mathrm{PB}+\mathrm{OB} / \text { Supervised } / \mathrm{ML}+ \\
\mathrm{RF}\end{array}$ & Optical + Radar \\
\hline 235 & Whitley M. A. et al. [279] & 2018 & YT & - & $\begin{array}{l}\text { Optical + LiDAR + } \\
\text { LiDAR/DEM }\end{array}$ \\
\hline 236 & Jorgenson M. T. et al. [280] & 2018 & YT & - & $\begin{array}{l}\text { Optical + Aerial + } \\
\text { LiDAR/DEM }\end{array}$ \\
\hline 237 & Ward E. M. et al. [281] & 2018 & $\mathrm{AB}$ & - & Optical \\
\hline 238 & Potter C. [282] & 2018 & $\mathrm{YT}$ & - & Optical \\
\hline 239 & Campbell T. K. F. et al. [283] & 2018 & NT & - & Optical + Aerial \\
\hline 240 & Blanchette M. et al. [284] & 2018 & QC & - & $\begin{array}{l}\text { Optical + Aerial + } \\
\text { LiDAR/DEM }\end{array}$ \\
\hline 241 & Warren R. K. et al. [285] & 2018 & NT & - & Optical \\
\hline 242 & DeLancey E. R. et al. [286] & 2018 & $\mathrm{AB}$ & - & Radar + LiDAR/DEM \\
\hline 243 & Chasmer L. E. et al. [287] & 2018 & $\mathrm{AB}$ & - & Optical \\
\hline 244 & Montgomery J. S. et al. [288] & 2018 & $\mathrm{AB}$ & - & $\begin{array}{l}\text { Optical + Radar + } \\
\text { LiDAR/DEM }\end{array}$ \\
\hline 245 & Mahdavi S. et al. [82] & 2019 & NL & OB/Supervised/RF & Optical + Radar \\
\hline 246 & Merchant M. A. et al. [289] & 2019 & YT & $\begin{array}{l}\text { OB/Supervised/KNN + SVM } \\
+\mathrm{RF}\end{array}$ & $\begin{array}{l}\text { Optical + Radar + } \\
\text { LiDAR/DEM }\end{array}$ \\
\hline 247 & Pouliot D. et al. [54] & 2019 & $\mathrm{AB}, \mathrm{QC}$ & $\mathrm{PB} /$ Supervised $/ \mathrm{DL}=\mathrm{CNN}$ & Optical \\
\hline 248 & Amani M. et al. [68] & 2019 & Canada & $\mathrm{PB} /$ Supervised/RF & Optical \\
\hline 249 & Dabboor M. et al. [31] & 2019 & $\mathrm{ON}$ & - & Optical + Radar \\
\hline 250 & Mohammadimanesh F. et al. [28] & 2019 & NL & OB/Supervised/RF & Radar \\
\hline 251 & Rupasinghe P. A. et al. [46] & 2019 & $\mathrm{ON}$ & PB/Supervised/SVM & Optical + UAV \\
\hline 252 & DeLancey E. R. et al. [41] & 2019 & $\mathrm{AB}$ & PB/Supervised/DL & Optical + Radar + LiDAR \\
\hline 253 & Mahdianpari M. et al. [86] & 2019 & NL & $\mathrm{PB}+\mathrm{OB} /$ Supervised/RF & Optical + Radar \\
\hline 254 & Judah A. et al. [290] & 2019 & $\mathrm{ON}$ & $\begin{array}{l}\mathrm{PB} / \text { Supervised } / \mathrm{KNN}+\mathrm{SVM} \\
+\mathrm{RF}+\text { Other }\end{array}$ & Optical + Radar \\
\hline 255 & Banks S. et al. [45] & 2019 & $\mathrm{ON}$ & $\mathrm{PB} /$ Supervised/RF & Radar + DSM/DEM \\
\hline 256 & Pitcher L. H. et al. [291] & 2019 & YT & - & Radar \\
\hline 257 & Gonsamo A. et al. [292] & 2019 & $\mathrm{ON}$ & - & Optical \\
\hline 258 & Westwood A. et al. [293] & 2019 & NB, NS & - & Aerial \\
\hline 259 & Brisco B. et al. [294] & 2019 & $\mathrm{AB}$ & - & $\begin{array}{l}\text { Radar + UAV + LiDAR + } \\
\text { LiDAR/DEM }\end{array}$ \\
\hline 260 & Jensen D. et al. [295] & 2019 & $\mathrm{AB}$ & - & Optical \\
\hline 261 & Palumbo M. D. et al. [296] & 2019 & $\mathrm{ON}$ & - & Other \\
\hline 262 & Montgomery J. et al. [297] & 2019 & $\mathrm{AB}$ & - & Optical + Radar + LiDAR \\
\hline
\end{tabular}


Table A2. Cont.

\begin{tabular}{|c|c|c|c|c|c|}
\hline No. & First Author & Year & Region & Classification Method & Data \\
\hline 263 & Amani M. et al. [78] & 2019 & NL & - & Radar \\
\hline 264 & Lane D. et al. [298] & 2019 & $\mathrm{ON}$ & - & LiDAR/DEM \\
\hline 265 & Mahdianpari M. et al. [299] & 2020 & NL & $\begin{array}{l}\text { PB/Supervised/RF + CART + } \\
\text { Other }\end{array}$ & Optical + DEM \\
\hline 266 & Mahdianpari M. et al. [69] & 2020 & Canada & OB/Supervised/RF & Optical + Radar \\
\hline 267 & Chen Z. et al. [300] & 2020 & $\mathrm{ON}$ & - & Radar + Optical + UAV \\
\hline 268 & DeLancey E. R. et al. [21] & 2020 & $\mathrm{AB}$ & $\mathrm{PB} /$ Supervised $/ \mathrm{DL}=\mathrm{CNN}$ & Radar + Optical + Aerial \\
\hline 269 & Merchant M. et al. [301] & 2020 & NT & OB/Supervised/RF & Optical + Radar + DEM \\
\hline 270 & Siles G. et al. [302] & 2020 & $\mathrm{AB}$ & OB/Supervised/ML + Other & $\begin{array}{l}\text { Optical + Radar + } \\
\text { LiDAR/DEM }\end{array}$ \\
\hline 271 & White L. et al. [303] & 2020 & $\mathrm{QC}$ & $\mathrm{PB} /$ Supervised/Other & Radar + UAV \\
\hline 272 & Valenti V. L. et al. [59] & 2020 & $\mathrm{ON}$ & PB/Supervised/RF & Optical + Radar \\
\hline 273 & Hawkes V. C. et al. [304] & 2020 & $\mathrm{AB}$ & Visual Analysis/Other & $\begin{array}{l}\text { Optical + Aerial + } \\
\text { LiDAR/DEM }\end{array}$ \\
\hline 274 & Brisco B. et al. [305] & 2020 & Canada & - & Radar \\
\hline 275 & Amani M. et al. [120] & 2020 & NL & $\mathrm{OB}+\mathrm{PB} /$ Supervised $/ \mathrm{RF}$ & Optical + Radar + LiDAR \\
\hline 276 & Mahdianpari M. et al. [70] & 2020 & Canada & $\mathrm{OB} /$ Supervised/RF & Optical + Radar \\
\hline 277 & LaRocque A. et al. [306] & 2020 & NB & $\mathrm{PB} /$ Supervised/RF & Optical + Radar \\
\hline 278 & LaRocque A. et al. [117] & 2020 & NB & PB/Supervised/RF & Optical + Radar + DEM \\
\hline 279 & Ahmed, M. I. et al. [307] & 2020 & SK & - & DEM \\
\hline 280 & Bahrami A. et al. [308] & 2020 & QC & - & Radar + Other \\
\hline 281 & Bergeron J. et al. [309] & 2020 & $\mathrm{AB}$ & - & $\begin{array}{l}\text { Optical + LiDAR + } \\
\text { LiDAR/DEM }\end{array}$ \\
\hline 282 & Mahoney C. et al. [310] & 2020 & $\mathrm{AB}$ & - & Radar \\
\hline 283 & Wulder M. A. et al. [311] & 2020 & Canada & - & Optical + LiDAR \\
\hline 284 & Janardanan R. et al. [312] & 2020 & Canada & - & Optical + UAV \\
\hline 285 & O'Sullivan A. M. et al. [313] & 2020 & NB & - & LiDAR/DEM \\
\hline 286 & Olthof I. et al. [314] & 2020 & $\mathrm{QC}, \mathrm{ON}$ & - & Radar \\
\hline 287 & Wadsworth E. et al. [315] & 2020 & Canada & - & LiDAR/DEM + Other \\
\hline 288 & Amani M. et al. [316] & 2020 & Canada & - & Optical \\
\hline 289 & Omari K. et al. [317] & 2020 & $\mathrm{QC}$ & - & Radar \\
\hline 290 & Sewell P. D. et al. [318] & 2020 & $\mathrm{AB}$ & - & LiDAR \\
\hline 291 & Peters D. L. et al. [319] & 2020 & $\mathrm{AB}$ & - & Optical + LiDAR \\
\hline 292 & Zakharov I. et al. [320] & 2020 & $\mathrm{AB}$ & - & Radar \\
\hline 293 & Wulder M. A. et al. [321] & 2020 & Canada & - & Optical \\
\hline 294 & Wang L. et al. [322] & 2020 & QC & - & Radar \\
\hline 295 & White L. et al. [323] & 2020 & $\mathrm{ON}$ & - & - \\
\hline 296 & Wu J. et al. [324] & 2020 & NL & - & - \\
\hline 297 & Haynes K. M. et al. [325] & 2020 & NT & - & LiDAR \\
\hline 298 & Hopkinson C. et al. [326] & 2020 & $\mathrm{BC}$ & - & $\begin{array}{l}\text { Optical + Radar + } \\
\text { LiDAR/DEM }\end{array}$ \\
\hline 299 & Adeli S. et al. [18] & 2020 & Canada & - & - \\
\hline 300 & Mahdianpari M. et al. [327] & 2020 & NL & OB/Supervised/RF & Optical + LiDAR/DEM \\
\hline
\end{tabular}

* PB and OB stand for Pixel-Based and Object-Based, respectively.

\section{References}

1. Why Wetlands. Available online: http://www.wetlands-initiative.org/what-is-a-wetland (accessed on 21 January 2021).

2. Mahdavi, S.; Salehi, B.; Granger, J.; Amani, M.; Brisco, B.; Huang, W. Remote Sensing for Wetland Classification: A Comprehensive Review. GISci. Remote Sens. 2018, 55, 623-658. [CrossRef]

3. Grenier, M.; Labrecque, S.; Garneau, M.; Tremblay, A. Object-Based Classification of a SPOT-4 Image for Mapping Wetlands in the Context of Greenhouse Gases Emissions: The Case of the Eastmain Region, Québec, Canada. Can. J. Remote Sens. 2008, 34, S398-S413. [CrossRef]

4. Trepel, M. Assessing the Cost-Effectiveness of the Water Purification Function of Wetlands for Environmental Planning. Ecol. Complex. 2010, 7, 320-326. [CrossRef]

5. Knox, A.K.; Dahlgren, R.A.; Tate, K.W.; Atwill, E.R. Efficacy of Natural Wetlands to Retain Nutrient, Sediment and Microbial Pollutants. J. Environ. Qual. 2008, 37, 1837-1846. [CrossRef] [PubMed]

6. Claassen, R. Compliance Provisions for Soil and Wetland Conservation. In Agricultural Resources and Environmental Indicators; Wiebe, K., Gollehon, N., Eds.; Nova Science Publishers, Inc.: Hauppauge, NY, USA, 2006; ISBN 978-1-60021-467-7. 
7. Amani, M.; Salehi, B.; Mahdavi, S.; Granger, J.; Brisco, B. Wetland Classification in Newfoundland and Labrador Using MultiSource SAR and Optical Data Integration. GISci. Remote Sens. 2017, 54, 779-796. [CrossRef]

8. Zedler, J.; Leach, M. Managing Urban Wetlands for Multiple Use: Research, Restoration, and Recreation. Urban Ecosyst. 1998, 2, 189-204. [CrossRef]

9. Li, X.; Bellerby, R.; Craft, C.; Widney, S.E. Coastal Wetland Loss, Consequences, and Challenges for Restoration. Anthr. Coasts 2018, 1, 1-15. [CrossRef]

10. Ming, J.; Xian-guo, L.; Lin-shu, X.; Li-juan, C.; Shouzheng, T. Flood Mitigation Benefit of Wetland Soil-A Case Study in Momoge National Nature Reserve in China. Ecol. Econ. 2007, 61, 217-223. [CrossRef]

11. Allard, M.; Fournier, R.A.; Grenier, M.; Lefebvre, J.; Giroux, J.F. Forty Years of Change in the Bulrush Marshes of the St. Lawrence Estuary and the Impact of the Greater Snow Goose. Wetlands 2012, 32, 1175-1188. [CrossRef]

12. Strong, L.L.; Cowardin, L.M. Improving Prairie Pond Counts with Aerial Video and Global Positioning Systems. J. Wildl. Manag. 1995, 59, 708. [CrossRef]

13. Koch, M.; Schmid, T.; Reyes, M.; Gumuzzio, J. Evaluating Full Polarimetric C- and L-Band Data for Mapping Wetland Conditions in a Semi-Arid Environment in Central Spain. IEEE J. Sel. Top. Appl. Earth Obs. Remote Sens. 2012, 5, 1033-1044. [CrossRef]

14. Castro, G.; Chomitz, K.; Thomas, T.S. The Ramsar Convention: Measuring Its Effectiveness for Conserving Wetlands of International Importance. In Proceedings of the Ramsar COP8, Valencia, Spain, 18-26 November 2002.

15. Grobicki, A.; Chalmers, C.; Jennings, E.; Jones, T.; Peck, D. An Introduction to the Ramsar Convention on Wetlands, 7th ed.; Ramsar Convention Secretariat: Gland, Switzerland, 2016.

16. Dabboor, M.; White, L.; Brisco, B.; Charbonneau, F. Change Detection with Compact Polarimetric SAR for Monitoring Wetlands. Can. J. Remote Sens. 2015, 41, 408-417. [CrossRef]

17. Mahdianpari, M.; Granger, J.E.; Mohammadimanesh, F.; Salehi, B.; Brisco, B.; Homayouni, S.; Gill, E.; Huberty, B.; Lang, M. Meta-Analysis of Wetland Classification Using Remote Sensing: A Systematic Review of a 40-Year Trend in North America. Remote Sens. 2020, 12, 1882. [CrossRef]

18. Adeli, S.; Salehi, B.; Mahdianpari, M.; Quackenbush, L.J.; Brisco, B.; Tamiminia, H.; Shaw, S. Wetland Monitoring Using SAR Data: A Meta-Analysis and Comprehensive Review. Remote Sens. 2020, 12, 2190. [CrossRef]

19. Dribault, Y.; Chokmani, K.; Bernier, M. Monitoring Seasonal Hydrological Dynamics of Minerotrophic Peatlands Using Multi-Date GeoEye-1 Very High Resolution Imagery and Object-Based Classification. Remote Sens. 2012, 4, 1887-1912. [CrossRef]

20. Arroyo-Mora, J.P.; Kalacska, M.; Soffer, R.; Ifimov, G.; Leblanc, G.; Schaaf, E.S.; Lucanus, O. Evaluation of Phenospectral Dynamics with Sentinel-2A Using a Bottom-up Approach in a Northern Ombrotrophic Peatland. Remote Sens. Environ. 2018, 216, 544-560. [CrossRef]

21. DeLancey, E.R.; Simms, J.F.; Mahdianpari, M.; Brisco, B.; Mahoney, C.; Kariyeva, J. Comparing Deep Learning and Shallow Learning for Large-Scalewetland Classification in Alberta, Canada. Remote Sens. 2020, 12, 2. [CrossRef]

22. Halsey, L.; Vitt, D.; Zoltai, S. Climatic and Physiographic Controls on Wetland Type and Distribution in Manitoba, Canada. Wetlands 1997, 17, 243-262. [CrossRef]

23. McNairn, H.E.; Protz, R.; Duke, C. Scale and Remotely Sensed Data for Change Detection in the James Bay, Ontario, Coastal Wetlands. Can. J. Remote Sens. 1993, 19, 45-49. [CrossRef]

24. Zaman, B.; Jensen, A.M.; McKee, M. Use of High-Resolution Multispectral Imagery Acquired with an Autonomous Unmanned Aerial Vehicle to Quantify the Spread of an Invasive Wetlands Species. In Proceedings of the International Geoscience and Remote Sensing Symposium (IGARSS), Vancouver, BC, Canada, 24-29 July 2011; pp. 803-806.

25. Wang, J.; Shang, J.; Brisco, B.; Brown, R.J. Evaluation of Multidate ERS-1 and Multispectral Landsat Imagery for Wetland Detection in Southern Ontario. Can. J. Remote Sens. 1998, 24, 60-68. [CrossRef]

26. Mutanga, O.; Adam, E.; Cho, M.A. High Density Biomass Estimation for Wetland Vegetation Using WorldView-2 Imagery and Random Forest Regression Algorithm. Int. J. Appl. Earth Obs. Geoinf. 2012, 18, 399-406. [CrossRef]

27. Mahdianpari, M.; Salehi, B.; Rezaee, M.; Mohammadimanesh, F.; Zhang, Y. Very Deep Convolutional Neural Networks for Complex Land Cover Mapping Using Multispectral Remote Sensing Imagery. Remote Sens. 2018, 10, 1119. [CrossRef]

28. Mohammadimanesh, F.; Salehi, B.; Mahdianpari, M.; Brisco, B.; Gill, E. Full and Simulated Compact Polarimetry SAR Responses to Canadian Wetlands: Separability Analysis and Classification. Remote Sens. 2019, 11, 516. [CrossRef]

29. Murphy, M.A.; Martini, J.P.; Protz, R. Seasonal Changes in Subarctic Wetlands and River Ice Breakup Detectable on RADARSAT Images, Southern Hudson Bay Lowland, Ontario, Canada. Can. J. Remote Sens. 2001, 27, 143-158. [CrossRef]

30. Ghedira, H.; Bernier, M.; Ouarda, T.B.M.J. Application of Neural Networks for Wetland Classification in RADARSAT SAR Imagery. In Proceedings of the International Geoscience and Remote Sensing Symposium (IGARSS), Honolulu, HI, USA, 24-28 July 2000; Volume 2, pp. 675-677.

31. Dabboor, M.; Banks, S.; White, L.; Brisco, B.; Behnamian, A.; Chen, Z.; Murnaghan, K. Comparison of Compact and Fully Polarimetric SAR for Multitemporal Wetland Monitoring. IEEE J. Sel. Top. Appl. Earth Obs. Remote Sens. 2019, 12, 1417-1430. [CrossRef]

32. Jollineau, M.Y.; Howarth, P.J. Mapping an Inland Wetland Complex Using Hyperspectral Imagery. Int. J. Remote Sens. 2008, 29, 3609-3631. [CrossRef]

33. Li, J.; Chen, W. A Rule-Based Method for Mapping Canada's Wetlands Using Optical, Radar and DEM Data. Int. J. Remote Sens. 2005, 26, 5051-5069. [CrossRef] 
34. Braverman, M.; Quinton, W.L. Hydrological Impacts of Seismic Lines in the Wetland-Dominated Zone of Thawing, Discontinuous Permafrost, Northwest Territories, Canada. Hydrol. Process. 2016, 30, 2617-2627. [CrossRef]

35. Hogg, A.R.; Todd, K.W. Automated Discrimination of Upland and Wetland Using Terrain Derivatives. Can. J. Remote Sens. 2007, 33, S68-S83. [CrossRef]

36. Richardson, M.C.; Fortin, M.J.; Branfireun, B.A. Hydrogeomorphic Edge Detection and Delineation of Landscape Functional Units from Lidar Digital Elevation Models. Water Resour. Res. 2009, 45, 10441. [CrossRef]

37. Collin, A.; Long, B.; Archambault, P. Salt-Marsh Characterization, Zonation Assessment and Mapping through a Dual-Wavelength LiDAR. Remote Sens. Environ. 2010, 114, 520-530. [CrossRef]

38. Sutherland, G.; Chasmer, L.E.; Petrone, R.M.; Kljun, N.; Devito, K.J. Evaluating the Use of Spatially Varying versus Bulk Average 3D Vegetation Structural Inputs to Modelled Evapotranspiration within Heterogeneous Land Cover Types. Ecohydrology 2014, 7, 1545-1559. [CrossRef]

39. Amani, M.; Salehi, B.; Mahdavi, S.; Brisco, B. Spectral Analysis of Wetlands Using Multi-Source Optical Satellite Imagery. ISPRS J. Photogramm. Remote Sens. 2018, 144, 119-136. [CrossRef]

40. Hird, J.N.; DeLancey, E.R.; McDermid, G.J.; Kariyeva, J. Google Earth Engine, Open-Access Satellite Data, and Machine Learning in Support of Large-Area Probabilisticwetland Mapping. Remote Sens. 2017, 9, 1315. [CrossRef]

41. DeLancey, E.R.; Kariyeva, J.; Bried, J.T.; Hird, J.N. Large-Scale Probabilistic Identification of Boreal Peatlands Using Google Earth Engine, Open-Access Satellite Data, and Machine Learning. PLoS ONE 2019, 14, e0218165. [CrossRef]

42. Millard, K.; Richardson, M. Wetland Mapping with LiDAR Derivatives, SAR Polarimetric Decompositions, and LiDAR-SAR Fusion Using a Random Forest Classifier. Can. J. Remote Sens. 2013, 39, 290-307. [CrossRef]

43. Mahdianpari, M.; Salehi, B.; Mohammadimanesh, F.; Brisco, B. An Assessment of Simulated Compact Polarimetric SAR Data for Wetland Classification Using Random Forest Algorithm. Can. J. Remote Sens. 2017, 43, 468-484. [CrossRef]

44. Mahdianpari, M.; Salehi, B.; Mohammadimanesh, F.; Motagh, M. Random Forest Wetland Classification Using ALOS-2 L-Band, RADARSAT-2 C-Band, and TerraSAR-X Imagery. ISPRS J. Photogramm. Remote Sens. 2017, 130, 13-31. [CrossRef]

45. Banks, S.; White, L.; Behnamian, A.; Chen, Z.; Montpetit, B.; Brisco, B.; Pasher, J.; Duffe, J. Wetland Classification with MultiAngle/Temporal SAR Using Random Forests. Remote Sens. 2019, 11, 670. [CrossRef]

46. Rupasinghe, P.A.; Chow-Fraser, P. Identification of Most Spectrally Distinguishable Phenological Stage of Invasive Phramites Australis in Lake Erie Wetlands (Canada) for Accurate Mapping Using Multispectral Satellite Imagery. Wetl. Ecol. Manag. 2019, 27, 513-538. [CrossRef]

47. Merchant, M.A.; Adams, J.R.; Berg, A.A.; Baltzer, J.L.; Quinton, W.L.; Chasmer, L.E. Contributions of C-Band SAR Data and Polarimetric Decompositions to Subarctic Boreal Peatland Mapping. IEEE J. Sel. Top. Appl. Earth Obs. Remote Sens. 2017, 10, 1467-1482. [CrossRef]

48. Brisco, B.; Li, K.; Tedford, B.; Charbonneau, F.; Yun, S.; Murnaghan, K. Compact Polarimetry Assessment for Rice and Wetland Mapping. Int. J. Remote Sens. 2013, 34, 1949-1964. [CrossRef]

49. Kaheil, Y.H.; Creed, I.F. Detecting and Downscaling Wet Areas on Boreal Landscapes. IEEE Geosci. Remote Sens. Lett. 2009, 6, 179-183. [CrossRef]

50. Yatabe, S.M.; Leckie, D.G. Clearcut and Forest-Type Discrimination in Satellite Sar Imagery. Can. J. Remote Sens. 1995, $21,455-467$. [CrossRef]

51. Jobin, B.; Beaulieu, J.; Grenier, M.; Bélanger, L.; Maisonneuve, C.; Bordage, D.; Filion, B. Landscape Changes and Ecological Studies in Agricultural Regions, Québec, Canada. Landsc. Ecol. 2003, 18, 575-590. [CrossRef]

52. Ullmann, T.; Schmitt, A.; Roth, A.; Duffe, J.; Dech, S.; Hubberten, H.W.; Baumhauer, R. Land Cover Characterization and Classification of Arctic Tundra Environments by Means of Polarized Synthetic Aperture X- and C-Band Radar (PolSAR) and Landsat 8 Multispectral Imagery—Richards Island, Canada. Remote Sens. 2014, 6, 8565-8593. [CrossRef]

53. Chabot, D.; Dillon, C.; Shemrock, A.; Weissflog, N.; Sager, E.P.S. An Object-Based Image Analysis Workflow for Monitoring Shallow-Water Aquatic Vegetation in Multispectral Drone Imagery. ISPRS Int. J. Geo-Inf. 2018, 7, 294. [CrossRef]

54. Pouliot, D.; Latifovic, R.; Pasher, J.; Duffe, J. Assessment of Convolution Neural Networks for Wetland Mapping with Landsat in the Central Canadian Boreal Forest Region. Remote Sens. 2019, 11, 772. [CrossRef]

55. Bourgeau-Chavez, L.L.; Endres, S.; Powell, R.; Battaglia, M.J.; Benscoter, B.; Turetsky, M.; Kasischke, E.S.; Banda, E. Mapping Boreal Peatland Ecosystem Types from Multitemporal Radar and Optical Satellite Imagery. Can. J. For. Res. 2017, 47, 545-559. [CrossRef]

56. Ou, C.; LaRocque, A.; Leblon, B.; Zhang, Y.; Webster, K.; McLaughlin, J. Modelling and Mapping Permafrost at High Spatial Resolution Using Landsat and Radarsat-2 Images in Northern Ontario, Canada: Part 2-Regional Mapping. Int. J. Remote Sens. 2016, 37, 2751-2779. [CrossRef]

57. Chen, Z.; Pasher, J.; Duffe, J.; Behnamian, A. Mapping Arctic Coastal Ecosystems with High Resolution Optical Satellite Imagery Using a Hybrid Classification Approach. Can. J. Remote Sens. 2017, 43, 513-527. [CrossRef]

58. Banks, S.; Millard, K.; Behnamian, A.; White, L.; Ullmann, T.; Charbonneau, F.; Chen, Z.; Wang, H.; Pasher, J.; Duffe, J. Contributions of Actual and Simulated Satellite SAR Data for Substrate Type Differentiation and Shoreline Mapping in the Canadian Arctic. Remote Sens. 2017, 9, 1206. [CrossRef] 
59. Valenti, V.L.; Carcelen, E.C.; Lange, K.; Russo, N.J.; Chapman, B. Leveraging Google Earth Engine User Interface for Semiautomated Wetland Classification in the Great Lakes Basin at $10 \mathrm{~m}$ with Optical and Radar Geospatial Datasets. IEEE J. Sel. Top. Appl. Earth Obs. Remote Sens. 2020, 13, 6008-6018. [CrossRef]

60. White, L.; Millard, K.; Banks, S.; Richardson, M.; Pasher, J.; Duffe, J. Moving to the RADARSAT Constellation Mission: Comparing Synthesized Compact Polarimetry and Dual Polarimetry Data with Fully Polarimetric RADARSAT-2 Data for Image Classification of Peatlands. Remote Sens. 2017, 9, 573. [CrossRef]

61. Franklin, S.E.; Ahmed, O.S. Object-Based Wetland Characterization Using Radarsat-2 Quad-Polarimetric SAR Data, Landsat-8 OLI Imagery, and Airborne Lidar-Derived Geomorphometric Variables. Photogramm. Eng. Remote Sens. 2017, 83, 27-36. [CrossRef]

62. Franklin, S.E.; Skeries, E.M.; Stefanuk, M.A.; Ahmed, O.S. Wetland Classification Using Radarsat-2 SAR Quad-Polarization and Landsat-8 OLI Spectral Response Data: A Case Study in the Hudson Bay Lowlands Ecoregion. Int. J. Remote Sens. 2018, 39, 1615-1627. [CrossRef]

63. Lantz, N.J.; Wang, J. Object-Based Classification of Worldview-2 Imagery for Mapping Invasive Common Reed, Phragmites Australis. Can. J. Remote Sens. 2013, 39, 328-340. [CrossRef]

64. Melton, J.R.; Wania, R.; Hodson, E.L.; Poulter, B.; Ringeval, B.; Spahni, R.; Bohn, T.; Avis, C.A.; Beerling, D.J.; Chen, G.; et al. Present State of Global Wetland Extent and Wetland Methane Modelling: Conclusions from a Model Inter-Comparison Project (WETCHIMP). Biogeosciences 2013, 10, 753-788. [CrossRef]

65. Canadian Environmental Sustainability Indicators: Extent of Canada's Wetlands. 2016. Available online: https://www.canada. $\mathrm{ca} /$ content/dam/eccc/migration/main/indicateurs-indicators/69e2d25b-52a2-451e-ad87-257fb13711b9/4.0.b-20wetlands_ en.pdf (accessed on 31 August 2016).

66. Wetlands. Available online: https://cwf-fcf.org/en/explore/gardening-for-wildlife/tools/recreating-natural-habitats/wetlands. html (accessed on 31 August 2016).

67. Warner, B.G.; Rubec, C.D.A.; National Wetlands Working Group. The Canadian Wetland Classification System; Wetlands Research Centre, University of Waterloo: Waterloo, ON, Canada, 1997.

68. Amani, M.; Mahdavi, S.; Afshar, M.; Brisco, B.; Huang, W.; Mirzadeh, S.M.J.; White, L.; Banks, S.; Montgomery, J.; Hopkinson, C. Canadian Wetland Inventory Using Google Earth Engine: The First Map and Preliminary Results. Remote Sens. 2019, 11, 842. [CrossRef]

69. Mahdianpari, M.; Salehi, B.; Mohammadimanesh, F.; Brisco, B.; Homayouni, S.; Gill, E.; DeLancey, E.R.; Bourgeau-Chavez, L. Big Data for a Big Country: The First Generation of Canadian Wetland Inventory Map at a Spatial Resolution of 10-m Using Sentinel-1 and Sentinel-2 Data on the Google Earth Engine Cloud Computing Platform. Can. J. Remote Sens. 2020, 46, 15-33. [CrossRef]

70. Mahdianpari, M.; Brisco, B.; Granger, J.E.; Mohammadimanesh, F.; Salehi, B.; Banks, S.; Homayouni, S.; Bourgeau-Chavez, L.; Weng, Q. The Second Generation Canadian Wetland Inventory Map at 10 Meters Resolution Using Google Earth Engine. Can. J. Remote Sens. 2020, 46, 360-375. [CrossRef]

71. McLaren, B.E.; Mahoney, S.P. Comparison of Forestry-Based Remote Sensing Methodologies to Evaluate Woodland Caribou Habitat in Non-Forested Areas of Newfoundland. For. Chron. 2001, 77, 866-873. [CrossRef]

72. Mahdavi, S.; Salehi, B.; Amani, M.; Granger, J.E.; Brisco, B.; Huang, W.; Hanson, A. Object-Based Classification of Wetlands in Newfoundland and Labrador Using Multi-Temporal PolSAR Data. Can. J. Remote Sens. 2017, 43, 432-450. [CrossRef]

73. Amani, M.; Salehi, B.; Mahdavi, S.; Granger, J.E.; Brisco, B.; Hanson, A. Wetland Classification Using Multi-Source and MultiTemporal Optical Remote Sensing Data in Newfoundland and Labrador, Canada. Can. J. Remote Sens. 2017, 43, 360-373. [CrossRef]

74. Chasmer, L.; Cobbaert, D.; Mahoney, C.; Millard, K.; Peters, D.; Devito, K.; Brisco, B.; Hopkinson, C.; Merchant, M.; Montgomery, J.; et al. Remote Sensing of Boreal Wetlands 1: Data Use for Policy and Management. Remote Sens. 2020, 12, 1320. [CrossRef]

75. Chasmer, L.; Mahoney, C.; Millard, K.; Nelson, K.; Peters, D.; Merchant, M.; Hopkinson, C.; Brisco, B.; Niemann, O.; Montgomery, J.; et al. Remote Sensing of Boreal Wetlands 2: Methods for Evaluating Boreal Wetland Ecosystem State and Drivers of Change. Remote Sens. 2020, 12, 1321. [CrossRef]

76. Guo, M.; Li, J.; Sheng, C.; Xu, J.; Wu, L. A Review of Wetland Remote Sensing. Sensors 2017, 17, 777. [CrossRef] [PubMed]

77. Branch, W.; Floor, M. Alberta Environment and Sustainable Resource Development (ESRD). 2015. Alberta Wetland Classification System; Water Policy Branch, Policy and Planning Division: Edmonton, AB, Canada, 2015; ISBN 9781460122570.

78. Amani, M.; Salehi, B.; Mahdavi, S.; Brisco, B. Separability Analysis of Wetlands in Canada Using Multi-Source SAR Data. GISci. Remote Sens. 2019, 56, 1233-1260. [CrossRef]

79. National Wetlands Working Group. Canada. Lands Directorate. The Canadian Wetland Classification System; Environment Canada: Ottawa, ON, Canada, 1987.

80. Smith, K.B.; Smith, C.; Forest, S.; Richard, A. A Field Guide to the Wetlands of the Boreal Plains Ecozone of Canada; Ducks Unlimited Canada, Western Boreal Office: Edmonton, AB, Canada, 2007.

81. Rubec, C. The Canadian Wetland Classification System. In Finlay; Springer: Dordrecht, The Netherlands, 2018; ISBN 978-90-481-3493-9.

82. Mahdavi, S.; Salehi, B.; Amani, M.; Granger, J.; Brisco, B.; Huang, W. A Dynamic Classification Scheme for Mapping Spectrally Similar Classes: Application to Wetland Classification. Int. J. Appl. Earth Obs. Geoinf. 2019, 83, 101914. [CrossRef]

83. Mahdianpari, M.; Salehi, B.; Mohammadimanesh, F.; Brisco, B.; Mahdavi, S.; Amani, M.; Granger, J.E. Fisher Linear Discriminant Analysis of Coherency Matrix for Wetland Classification Using PolSAR Imagery. Remote Sens. Environ. 2018, 206, 300-317. [CrossRef] 
84. Moher, D.; Shamseer, L.; Clarke, M.; Ghersi, D.; Liberati, A.; Petticrew, M.; Shekelle, P.; Stewart, L.A.; Group, P.-P. Preferred Reporting Items for Systematic Review and Meta-Analysis Protocols (PRISMA-P) 2015 Statement. Syst. Rev. 2015, 4, 1-9. [CrossRef]

85. Zupic, I.; Čater, T. Bibliometric Methods in Management and Organization. Organ. Res. Methods 2015, 18, 429-472. [CrossRef]

86. Mahdianpari, M.; Salehi, B.; Mohammadimanesh, F.; Homayouni, S.; Gill, E. The First Wetland Inventory Map of Newfoundland at a Spatial Resolution of $10 \mathrm{~m}$ Using Sentinel-1 and Sentinel-2 Data on the Google Earth Engine Cloud Computing Platform. Remote Sens. 2019, 11, 43. [CrossRef]

87. Kokelj, S.V.; Jorgenson, M.T. Advances in Thermokarst Research. Permafr. Periglac. Process. 2013, 24, 108-119. [CrossRef]

88. Touzi, R. Target Scattering Decomposition in Terms of Roll-Invariant Target Parameters. IEEE Trans. Geosci. Remote Sens. 2007, 45, 73-84. [CrossRef]

89. Connon, R.F.; Quinton, W.L.; Craig, J.R.; Hayashi, M. Changing Hydrologic Connectivity Due to Permafrost Thaw in the Lower Liard River Valley, NWT, Canada. Hydrol. Process. 2014, 28, 4163-4178. [CrossRef]

90. Wulder, M.A.; Li, Z.; Campbell, E.M.; White, J.C.; Hobart, G.; Hermosilla, T.; Coops, N.C. A National Assessment Ofwetland Status and Trends for Canada's Forested Ecosystems Using 33 Years of Earth Observation Satellite Data. Remote Sens. 2018, 10, 1623. [CrossRef]

91. Hermosilla, T.; Wulder, M.A.; White, J.C.; Coops, N.C.; Hobart, G.W. Disturbance-Informed Annual Land Cover Classification Maps of Canada's Forested Ecosystems for a 29-Year Landsat Time Series. Can. J. Remote Sens. 2018, 44, 67-87. [CrossRef]

92. Watchorn, K.E.; Goldsborough, L.G.; Wrubleski, D.A.; Mooney, B.G. A Hydrogeomorphic Inventory of Coastal Wetlands of the Manitoba Great Lakes: Lakes Winnipeg, Manitoba, and Winnipegosis. J. Great Lakes Res. 2012, 38, 115-122. [CrossRef]

93. Steyaert, L.T.; Hall, F.G.; Loveland, T.R. Land Cover Mapping, Fire Regeneration, and Scaling Studies in the Canadian Boreal Forest with $1 \mathrm{Km}$ AVHRR and Landsat TM Data. J. Geophys. Res. Atmos. 1997, 102, 29581-29598. [CrossRef]

94. Jahncke, R.; Leblon, B.; Bush, P.; LaRocque, A. Mapping Wetlands in Nova Scotia with Multi-Beam RADARSAT-2 Polarimetric SAR, Optical Satellite Imagery, and Lidar Data. Int. J. Appl. Earth Obs. Geoinf. 2018, 68, 139-156. [CrossRef]

95. Dech, J.P.; Mayhew-Hammond, S.; James, A.L.; Pokharel, B. Modeling Canada Yew (Taxus Canadensis Marsh.) Distribution and Abundance in the Boreal Forest of Northeastern Ontario, Canada. Ecol. Indic. 2014, 36, 48-58. [CrossRef]

96. Mohammadimanesh, F.; Salehi, B.; Mahdianpari, M.; Brisco, B.; Motagh, M. Multi-Temporal, Multi-Frequency, and MultiPolarization Coherence and SAR Backscatter Analysis of Wetlands. ISPRS J. Photogramm. Remote Sens. 2018, 142, 78-93. [CrossRef]

97. Arzandeh, S.; Wang, J. Texture Evaluation of RADARSAT Imagery for Wetland Mapping. Can. J. Remote Sens. 2002, 28, 653-666. [CrossRef]

98. Lara, M.J.; Genet, H.; Mcguire, A.D.; Euskirchen, E.S.; Zhang, Y.; Brown, D.R.N.; Jorgenson, M.T.; Romanovsky, V.; Breen, A.; Bolton, W.R. Thermokarst Rates Intensify Due to Climate Change and Forest Fragmentation in an Alaskan Boreal Forest Lowland. Glob. Chang. Biol. 2016, 22, 816-829. [CrossRef] [PubMed]

99. Pastick, N.J.; Rigge, M.; Wylie, B.K.; Jorgenson, M.T.; Rose, J.R.; Johnson, K.D.; Ji, L. Distribution and Landscape Controls of Organic Layer Thickness and Carbon within the Alaskan Yukon River Basin. Geoderma 2014, 230-231, 79-94. [CrossRef]

100. Deslandes, S.; Grenier, M.; Bélanger, L.; Lacroix, G.; Zingraff, V. The Wetland Conservation Atlas of the St. Lawrence Valley Produced from Decision Tree Classifications of RADARSAT and Landsat Images. In Proceedings of the International Geoscience and Remote Sensing Symposium (IGARSS), Toronto, ON, Canada, 24-28 June 2002; Volume 5, pp. $2893-2895$.

101. Baghdadi, N.; Bernier, M.; Gauthier, R.; Neeson, I. Evaluation of C-Band SAR Data for Wetlands Mapping. Int. J. Remote Sens. 2001, 22, 71-88. [CrossRef]

102. Chasmer, L.; Hopkinson, C.; Veness, T.; Quinton, W.; Baltzer, J. A Decision-Tree Classification for Low-Lying Complex Land Cover Types within the Zone of Discontinuous Permafrost. Remote Sens. Environ. 2014, 143, 73-84. [CrossRef]

103. Amani, M.; Salehi, B.; Mahdavi, S.; Brisco, B.; Shehata, M. A Multiple Classifier System to Improve Mapping Complex Land Covers: A Case Study of Wetland Classification Using SAR Data in Newfoundland, Canada. Int. J. Remote Sens. 2018, 39, 7370-7383. [CrossRef]

104. Gillanders, S.N.; Coops, N.C.; Wulder, M.A.; Goodwin, N.R. Application of Landsat Satellite Imagery to Monitor Land-Cover Changes at the Athabasca Oil Sands, Alberta, Canada. Can. Geogr. 2008, 52, 466-485. [CrossRef]

105. Gadallah, F.L. Historical Vegetation Reconstruction of a Degraded Sub-Arctic Coastal Marsh Using Landsat Imagery and Ancillary Data. Ecoscience 2002, 9, 271-279. [CrossRef]

106. Hall, F.G.; Knapp, D.E.; Huemmrich, K.F. Physically Based Classification and Satellite Mapping of Biophysical Characteristics in the Southern Boreal Forest. J. Geophys. Res. Atmos. 1997, 102, 29567-29580. [CrossRef]

107. Mui, A.; He, Y.; Weng, Q. An Object-Based Approach to Delineate Wetlands across Landscapes of Varied Disturbance with High Spatial Resolution Satellite Imagery. ISPRS J. Photogramm. Remote Sens. 2015, 109, 30-46. [CrossRef]

108. Dissanska, M.; Bernier, M.; Payette, S. Object-Based Classification of Very High Resolution Panchromatic Images for Evaluating Recent Change in the Structure of Patterned Peatlands. Can. J. Remote Sens. 2009, 35, 189-215. [CrossRef]

109. Dillabaugh, K.A.; King, D.J. Riparian Marshland Composition and Biomass Mapping Using Ikonos Imagery. Can. J. Remote Sens. 2008, 34, 143-158. [CrossRef]

110. Bernier, M.; Ghedira, H.; Gauthier, Y.; Magagi, R.; Filion, R.; De Sève, D.; Ouarda, T.B.M.J.; Villeneuve, J.P.; Buteau, P. Détection et Classification de Tourbières Ombrotrophes Du Québec à Partir d'images RADARSAT-1. Can. J. Remote Sens. 2003, 29, 88-98. [CrossRef] 
111. Dechka, J.A.; Franklin, S.E.; Watmough, M.D.; Bennett, R.P.; Ingstrup, D.W. Classification of Wetland Habitat and Vegetation Communities Using Multi-Temporal Ikonos Imagery in Southern Saskatchewan. Can. J. Remote Sens. 2002, 28, 679-685. [CrossRef]

112. Mohammadimanesh, F.; Salehi, B.; Mahdianpari, M.; Homayouni, S. Unsupervised Wishart Classfication of Wetlands in Newfoundland, Canada Using Polsar Data Based on Fisher Linear Discriminant Analysis. In Proceedings of the International Archives of the Photogrammetry, Remote Sensing and Spatial Information Sciences-ISPRS Archives, Prague, Czech Republic, 12-19 July 2016; Volume 41, pp. 305-310.

113. Paul, S.S.; Li, J.; Wheate, R.; Li, Y. Application of Object Oriented Image Classification and Markov Chain Modeling for Land Use and Land Cover Change Analysis. J. Environ. Inform. 2018, 31, 30-40. [CrossRef]

114. Sizo, A.; Noble, B.; Bell, S. Futures Analysis of Urban Land Use and Wetland Change in Saskatoon, Canada: An Application in Strategic Environmental Assessment. Sustaininability 2015, 7, 811-830. [CrossRef]

115. Touzi, R.; Omari, K.; Sleep, B. Combination of Target Scattering Decomposition with the Optimum Degree of Polarization for Improved Classification of Boreal Peatlands in the Athabasca Region. In Proceedings of the International Geoscience and Remote Sensing Symposium (IGARSS), Quebec City, QC, Canada, 13-18 July 2014; pp. 1013-1016.

116. Gosselin, G.; Touzi, R.; Cavayas, F. Polarimetric Radarsat-2 Wetland Classificationusing the Touzi Decomposition: Case of the Lac Saint-Pierre Ramsar Wetland. Can. J. Remote Sens. 2014, 39, 491-506. [CrossRef]

117. LaRocque, A.; Phiri, C.; Leblon, B.; Pirotti, F.; Connor, K.; Hanson, A. Wetland Mapping with Landsat 8 OLI, Sentinel-1, ALOS-1 PALSAR, and LiDAR Data in Southern New Brunswick, Canada. Remote Sens. 2020, 12, 2095. [CrossRef]

118. Thomas, V.; Treitz, P.; Jelinski, D.; Miller, J.; Lafleur, P.; McCaughey, J.H. Image Classification of a Northern Peatland Complex Using Spectral and Plant Community Data. Remote Sens. Environ. 2003, 84, 83-99. [CrossRef]

119. You, Y.; Cao, J.; Zhou, W. A Survey of Change Detection Methods Based on Remote Sensing Images for Multi-Source and Multi-Objective Scenarios. Remote Sens. 2020, 12, 2460. [CrossRef]

120. Amani, M.; Mahdavi, S.; Berard, O. Supervised Wetland Classification Using High Spatial Resolution Optical, SAR, and LiDAR Imagery. J. Appl. Remote Sens. 2020, 14, 1. [CrossRef]

121. Amani, M.; Ghorbanian, A.; Ahmadi, S.A.; Kakooei, M.; Moghimi, A.; Mirmazloumi, S.M.; Moghaddam, S.H.A.; Mahdavi, S.; Ghahremanloo, M.; Parsian, S.; et al. Google Earth Engine Cloud Computing Platform for Remote Sensing Big Data Applications: A Comprehensive Review. IEEE J. Sel. Top. Appl. Earth Obs. Remote Sens. 2020, 13, 5326-5350. [CrossRef]

122. Moghimi, A.; Khazai, S.; Mohammadzadeh, A. An Improved Fast Level Set Method Initialized with a Combination of K-Means Clustering and Otsu Thresholding for Unsupervised Change Detection from SAR Images. Arab. J. Geosci. 2017, 10, 1-18. [CrossRef]

123. Marti-Cardona, B.; Lopez-Martinez, C.; Dolz-Ripolles, J.; Bladè-Castellet, E. ASAR Polarimetric, Multi-Incidence Angle and Multitemporal Characterization of Doñana Wetlands for Flood Extent Monitoring. Remote Sens. Environ. 2010, 114, $2802-2815$. [CrossRef]

124. Jeglum, J.K.; Boissonneau, A.N. Regional Level of Wetlands Mapping for the Northern Clay Section of Ontario. In Proceedings of the 5th Canadian Symposium on Remote Sensing, Edmonton, AB, Canada, 28-31 August 1978.

125. Boissonneau, A.N.; Jeglum, J.K. A regional level of wetlands mapping for the northern Clay Section of Ontario. In Proceedings of the 3rd Canadian Symposium on Remote Sensing, Edmonton, AB, Canada, 22-24 September 1975; pp. 349-357.

126. Wedler, E.; Kessler, R. Interpretation of Vegetative Cover in Wetlands Using Four-Channel SAR Imagery. In Proceedings of the 47th American Society of Photogrammetry, Annual Meeting, Washington, DC, USA, 22-27 February 1981; pp. 111-124.

127. Hughes, F.M.; Cordes, L.D. Peace-Athabasca Delta-Wetland in Transition ( Alberta, Canada). Geogr. Mag. 1981.

128. Neraasen, T.G.; Macaulay, A.J.; Mroczynski, R.P. Pintails and Pixels: A Potential Application of Landsat Technology to Waterfowl Habitat Inventory; Purdue University: West Lafayette, IN, USA, 1981.

129. Watson, E.K.; Ryswyk, V.A.N. Remote Sensing Applications for British Columbia Wetlands Using 35 Mm Aerial Photography. In Proceedings of the 7th Canadian Symposium on Remote Sensing, Winnipeg, MB, Canada, 8-11 September 1981; pp. $211-221$.

130. Tomlins, G.F.; Thomson, K.P.B. Toward an Operational, Satellite-Based, Wetland Monitoring Program for the Fraser River Estuary, British Columbia. In Proceedings of the 7th Canadian Symposium on Remote Sensing, Winnipeg, MB, Canada, 8-11 September 1981; pp. 74-82.

131. Pala, S.; Boissonneau, A. Wetland Classification Maps for the Hudson Bay Lowland. Le Nat. Can. 1982, 109, 653-659.

132. Lafrance, P.; Dubois, J.; Bonn, F. Remote Sensing of Humid Environments: Comparison of MSS, TM and SPOT Images [La Teledetection Des Milieux Humides: Comparaison Des Images MSS, TM et SPOT]. Nat. Can. 1987, 114, $433-448$.

133. Lafrance, P.; Dubois, J.; Bonn, F. Enhancement of a SPOT Simulation by Integration of Panchromatic into Multi-Spectral Mode: Example of Wetlands (Canada). Photo Interpret. Images Aeriennes Spat. 1988.

134. Peddle, D.R.; Franklin, S.E. High Resolution Satellite Image Texture for Moderate Relief Terrain Analysis. In Proceedings of the 12th Canadian Symposium on Remote Sensing Geoscience and Remote Sensing Symposium, Vancouver, BC, Canada, 10-14 July 1989; IEEE: Piscataway, NJ, USA, 1989; Volume 2, pp. 653-655.

135. Kneppeck, I.D.; Ahern, F.J. Stratification of a Regenerating Burned Forest in Alberta Using Thematic Mapper and C-SAR Images. In Proceedings of the Digest-International Geoscience and Remote Sensing Symposium (IGARSS), Vancouver, BC, Canada, 10-14 July 1989; Volume 3, pp. 1391-1396. 
136. Drieman, J.A.; Leckie, D.G.; Ahern, F.J. Multitemporal C-SAR for Forest Typing in Eastern Ontario. In Proceedings of the 12th Canadian Symposium on Remote Sensing Geoscience and Remote Sensing Symposium, Vancouver, BC, Canada, 10-14 July 1989; IEEE: Piscataway, NJ, USA, 1989; Volume 3, pp. 1376-1378.

137. Konrad, S.R.; Rempel, R.S. Cost-Effectiveness of Landsat TM Classification by Operations Staff. IEEE Trans. Geosci. Remote Sens. 1990, 28, 769-771. [CrossRef]

138. Franklin, S.E.; Peddle, D.R. Classification of SPOT HRV Imagery and Texture Features. Remote Sens. 1990, 11, 551-556. [CrossRef]

139. Matthews, S.B. An Assessment of Bison Habitat in the Mills/Mink Lakes Area, Northwest Territories, Using LANDSAT Thematic Mapper Data. Arctic 1991, 44, 75-80. [CrossRef]

140. Franklin, S.E.; Gillespie, R.T.; Titus, B.D.; Pike, D.B. Aerial and Satellite Sensor Detection of Kalmia Angustifolia at Forest Regeneration Sites in Central Newfoundland. Int. J. Remote Sens. 1994, 15, 2553-2557. [CrossRef]

141. Cihlar, J.; Manak, D.; Voisin, N. AVHRR Bidirectional Reflectance Effects and Compositing. Remote Sens. Environ. 1994, 48, 77-88. [CrossRef]

142. Franklin, S.E.; Titus, B.D.; Gillespie, R.T. Remote Sensing of Vegetation Cover at Forest Regeneration Sites. Glob. Ecol. Biogeogr. Lett. 1994, 4, 40-46. [CrossRef]

143. Bubier, J.L.; Moore, T.R.; Bellisario, L.; Comer, N.T.; Crill, P.M. Ecological Controls on Methane Emissions from a Northern Peatland Complex in the Zone of Discontinuous Permafrost, Manitoba, Canada. Glob. Biogeochem. Cycles 1995, 9, 455-470. [CrossRef]

144. Pietroniro, A.; Prowse, T.D.; Lalonde, V. Classifying Terrain in a Muskeg-Wetland Regime for Application to GRU-Type Distributed Hydrologic Models. Can. J. Remote Sens. 1996, 22, 45-52. [CrossRef]

145. Hall, F.G.; Sellers, P.J.; Williams, D.L. Initial Results from the Boreal Ecosystem-Atmosphere Experiment, BOREAS; The Finnish Society of Forest Science and The Finnish Forest Research Institute: Helsinki, Finland, 1996.

146. Franklin, S.E.; Gillespie, R.T.; Titus, B.D.; McCaffrey, T.M. Discrimination of Kalmia Angustifolia Using Compact Airborne Spectrographic Imager (CASI) Data. Can. J. Remote Sens. 1997, 23, 71-75. [CrossRef]

147. Collins, N.; Davis, L. Minimizing Impacts of Highway Construction on Freshwater Wetlands in Nova Scotia. In Ecological Reclamation in Canada at Century's Turn, Proceedings of the 35th Annual Meeting of the Canadian Society of Environmental Biologists, Regina, SK, Canada, 26-29 September 1995; University of Regina Press: Regina, SK, Canada, 1997; Volume 28, p. 80.

148. Pietroniro, A.; Prowse, T.; Peters, D.L. Hydrologic Assessment of an Inland Freshwater Delta Using Multi-temporal Satellite Remote Sensing. Hydrol. Process. 1999, 13, 2483-2498. [CrossRef]

149. Rapalee, G.; Steyaert, L.T.; Hall, F.G. Moss and Lichen Cover Mapping at Local and Regional Scales in the Boreal Forest Ecosystem of Central Canada. J. Geophys. Res. Atmos. 2001, 106, 33551-33563. [CrossRef]

150. Pietroniro, A.; Leconte, R.; Peters, D.L.; Prowse, T.D. Application of a Hydrodynamic Model in a Freshwater Delta Using Remote Sensing. IAHS Publ. 2001, 519-525.

151. Hall-Atkinson, C.; Smith, L.C. Delineation of Delta Ecozones Using Interferometric SAR Phase Coherence: Mackenzie River Delta, NWT, Canada. Remote Sens. Environ. 2001, 78, 229-238. [CrossRef]

152. Sokol, J.; Pultz, T.J.; Bulzgis, V. Monitoring Wetland Hydrology in Atlantic Canada Using Multi-Temporal and Multi-Beam Radarsat Data. IAHS Publ. 2001, 526-530.

153. Jollineau, M.; Howarth, P. Use of High-Resolution Imagery to Map Wetland Environments in South-Central Ontario, Canada. In Proceedings of the IEEE International Geoscience and Remote Sensing Symposium, Toronto, ON, Canada, 24-28 June 2002; IEEE: Piscataway, NJ, USA, 2002; Volume 5, pp. 3089-3091.

154. Töyrä, J.; Pietroniro, A.; Martz, L.W.; Prowse, T.D. A Multi-sensor Approach to Wetland Flood Monitoring. Hydrol. Process. 2002, 16, 1569-1581. [CrossRef]

155. Pietroniro, A.; Toyra, J. A Multi-Sensor Remote Sensing Approach for Monitoring Large Wetland Complexes in Northern Canada. In Proceedings of the IEEE International Geoscience and Remote Sensing Symposium, Toronto, ON, Canada, 24-28 June 2002; IEEE: Piscataway, NJ, USA, 2002; Volume 2, pp. 1069-1072.

156. Poulin, M.; Careau, D.; Rochefort, L.; Desrochers, A. From Satellite Imagery to Peatland Vegetation Diversity: How Reliable Are Habitat Maps? Conserv. Ecol. 2002, 6. [CrossRef]

157. Quinton, W.L.; Hayashi, M.; Pietroniro, A. Connectivity and Storage Functions of Channel Fens and Flat Bogs in Northern Basins. Hydrol. Process. 2003, 17, 3665-3684. [CrossRef]

158. Bernier, M.; Ghedira, H.; Gauthier, Y.; Magagi, R.; Filion, R.; De Seve, D.; Ouarda, T.; Villeneuve, J.P.; Buteau, P. Remote Sensing and Classification Bogs in Quebec Using Radarsat-1 Images. Can. J. Remote Sens. 2003, 29, 88-98.

159. Arzandeh, S.; Wang, J. Monitoring the Change of Phragmites Distribution Using Satellite Data. Can. J. Remote Sens. 2003, 29, 24-35. [CrossRef]

160. Havholm, K.G.; Bergstrom, N.D.; Jol, H.M.; Running, G.L. GPR Survey of a Holocene Aeolian/Fluvial/Lacustrine Succession, Lauder Sandhills, Manitoba, Canada. Geol. Soc. Lon. Spec. Publ. 2003, 211, 47-54. [CrossRef]

161. Wessels, J.; Ball, D.; Prieto, D.F.; Ahern, F. Operational Wetlands Monitoring for the Ramsar Convention: TESEO Powers a Breakthrough. In Proceedings of the IGARSS 2003-2003 IEEE International Geoscience and Remote Sensing Symposium. Proceedings (IEEE Cat. No. 03CH37477), Toulouse, France, 21-25 July 2003; IEEE: Piscataway, NJ, USA, 2003; Volume 3, pp. $1486-1489$. 
162. Racine, M.-J.; Bernier, M.; Ouarda, T.B.M.J. Evaluation of RADARSAT-1 Images Acquired in Fine-Beam Mode for Boreal Peatlands: A Study in the La Grande River Watershed, James Bay, Québec, Canada. In Proceedings of the Remote Sensing for Environmental Monitoring, GIS Applications, and Geology IV; International Society for Optics and Photonics: Bellingham, WA, USA, 2004; Volume 5574, pp. 160-171.

163. Rosenqvist, A.; Shimada, M.; Chapman, B.; McDonald, K.; De Grandi, G.; Jonsson, H.; Williams, C.; Rauste, Y.; Nilsson, M.; Sango, D. An Overview of the JERS-1 SAR Global Boreal Forest Mapping (GBFM) Project. In Proceedings of the IGARSS 2004-2004 IEEE International Geoscience and Remote Sensing Symposium, Anchorage, AK, USA, 20-24 September 2004; IEEE: Piscataway, NJ, USA, 2004; Volume 2, pp. 1033-1036.

164. Sokol, J.; NcNairn, H.; Pultz, T.J. Case Studies Demonstrating the Hydrological Applications of C-Band Multipolarized and Polarimetric SAR. Can. J. Remote Sens. 2004, 30, 470-483. [CrossRef]

165. Tedford, B.; Hopkins, N.; Boychuk, L.; Kazmerik, B. “The Harder You Look, the More Wetlands You Will Find". An Evaluation of Wetland Identification Methods Utilizing Medium and High-Resolution Data Sources in the Glaciated Prairie Region of Canada. In Proceedings of the 26th Canadian Symposium on Remote Sensing, Wolfville, NS, Canada, 14-16 June 2005; p. 319.

166. Grenier, M.; Demers, A.-M.; Labrecque, S.; Fournier, R.A.; Drolet, B.; Benoit, M. A Classification Method to Map Wetlands in Quebec for the Canadian Wetland Inventory Using a Top-down Approach with Object-Oriented Segmentation. In Proceedings of the 26th Canadian Symposium on Remote Sensing, Wolfville, NS, Canada, 14-16 June 2005.

167. Cheng, W.F.; Satish, M.G.; Liu, L.; Pomeroy, J.; Mahoney, M. Development of an Integrated GIS and Remote Sensing Geodatabase for Wetland Assessment along a Proposed Highway in Southern Labrador, Canada. In Proceedings of the Annual ConferenceCanadian Society for Civil Engineering, Toronto, ON, Canada, 2-4 June 2005; pp. EV-159-1-EV-159-9.

168. Ju, W.; Chen, J.M. Distribution of Soil Carbon Stocks in Canada's Forests and Wetlands Simulated Based on Drainage Class, Topography and Remotely Sensed Vegetation Parameters. Hydrol. Process. Int. J. 2005, 19, 77-94. [CrossRef]

169. Hudon, C.; Gagnon, P.; Jean, M. Hydrological Factors Controlling the Spread of Common Reed (Phragmites Australis) in TheSt. Lawrence River (Québec, Canada). Ecoscience 2005, 12, 347-357. [CrossRef]

170. Niemann, K.O.; Moore, K.; Stockler, C.; Beaudet, F. Identification Coastal Seagrasses through the Fusion of Landsat and RADARSAT Imagery. In Proceedings of the 26th Canadian Symposium on Remote Sensing, Wolfville, NS, Canada, 14-16 June 2005; p. 483.

171. Smith, K.B.; Smith, C.E.; Richard, A.J. Mapping the Boreal Forest Using an Object-Oriented Earthcover Classification. In Proceedings of the 26th Canadian Symposium on Remote Sensing, Wolfville, NS, Canada, 14-16 June 2005; p. 223.

172. Li, J.; Chen, W.; Touzi, R. SAR Backscatter Characteristics of Wetlands in Mer Bleue. In Proceedings of the 26th Canadian Symposium on Remote Sensing, Wolfville, NS, Canada, 14-16 June 2005; p. 485.

173. Töyrä, J.; Pietroniro, A. Towards Operational Monitoring of a Northern Wetland Using Geomatics-Based Techniques. Remote Sens. Environ. 2005, 97, 174-191. [CrossRef]

174. Mialon, A.; Royer, A.; Fily, M. Wetland Seasonal Dynamics and Interannual Variability over Northern High Latitudes, Derived from Microwave Satellite Data. J. Geophys. Res. Atmos. 2005, 110. [CrossRef]

175. Brown, L.; Young, K.L. Assessment of Three Mapping Techniques to Delineate Lakes and Ponds in a Canadian High Arctic Wetland Complex. Arctic 2006, 59, 283-293. [CrossRef]

176. Prowse, T.D.; Beltaos, S.; Gardner, J.T.; Gibson, J.J.; Granger, R.J.; Leconte, R.; Peters, D.L.; Pietroniro, A.; Romolo, L.A.; Toth, B Climate Change, Flow Regulation and Land-Use Effects on the Hydrology of the Peace-Athabasca-Slave System; Findings from the Northern Rivers Ecosystem Initiative. Environ. Monit. Assess. 2006, 113, 167-197. [CrossRef] [PubMed]

177. Peters, D.L.; Prowse, T.D.; Pietroniro, A.; Leconte, R. Flood Hydrology of the Peace-Athabasca Delta, Northern Canada. Hydrol. Process. Int. J. 2006, 20, 4073-4096. [CrossRef]

178. Dillabaugh, K.; King, D. Wetland Composition and Productivity Mapping Using Ikonos Imagery. In Proceedings of the American Society for Photogrammetry and Remote Sensing-20th Biennial Workshop on Aerial Photography, Videography, and High Resolution Digital Imagery for Resource Assessment, Weslaco, TX, USA, 4-6 October 2005; pp. 516-523.

179. Li, J.; Chen, W.; Touzi, R. Optimum RADARSAT-1 Configurations for Wetlands Discrimination: A Case Study of the Mer Bleue Peat Bog. Can. J. Remote Sens. 2007, 33, S46-S55. [CrossRef]

180. Stevens, C.E.; Paszkowski, C.A.; Foote, A.L. Beaver (Castor Canadensis) as a Surrogate Species for Conserving Anuran Amphibians on Boreal Streams in Alberta, Canada. Biol. Conserv. 2007, 134, 1-13. [CrossRef]

181. Fournier, R.A.; Grenier, M.; Lavoie, A.; Hélie, R. Towards a Strategy to Implement the Canadian Wetland Inventory Using Satellite Remote Sensing. Can. J. Remote Sens. 2007, 33, S1-S16. [CrossRef]

182. Touzi, R.; Deschamps, A.; Rother, G. Wetland Characterization Using Polarimetric RADARSAT-2 Capability. Can. J. Remote Sens. 2007, 33, S56-S67. [CrossRef]

183. Hogg, A.R.; Holland, J. An Evaluation of DEMs Derived from LiDAR and Photogrammetry for Wetland Mapping. For. Chron. 2008, 84, 840-849. [CrossRef]

184. Sass, G.Z.; Creed, I.F. Characterizing Hydrodynamics on Boreal Landscapes Using Archived Synthetic Aperture Radar Imagery. Hydrol. Process. Int. J. 2008, 22, 1687-1699. [CrossRef]

185. Liu, Y.; Yang, W.; Wang, X. Development of a SWAT Extension Module to Simulate Riparian Wetland Hydrologic Processes at a Watershed Scale. Hydrol. Process. Int. J. 2008, 22, 2901-2915. [CrossRef] 
186. Creed, I.F.; Sass, G.Z.; Wolniewicz, M.B.; Devito, K.J. Incorporating Hydrologic Dynamics into Buffer Strip Design on the Sub-Humid Boreal Plain of Alberta. For. Ecol. Manag. 2008, 256, 1984-1994. [CrossRef]

187. Touzi, R.; Deschamps, A.; Rother, G. Scattering Type Phase for Wetland Classification Using C-Band Polarimetric SAR. In Proceedings of the IGARSS 2008-2008 IEEE International Geoscience and Remote Sensing Symposium, Boston, MA, USA, 7-11 July 2008; IEEE: Piscataway, NJ, USA, 2008; Volume 2, p. II-285.

188. Harris, A.; Bryant, R.G. A Multi-Scale Remote Sensing Approach for Monitoring Northern Peatland Hydrology: Present Possibilities and Future Challenges. J. Environ. Manag. 2009, 90, 2178-2188. [CrossRef]

189. Rosa, E.; Larocque, M.; Pellerin, S.; Gagné, S.; Fournier, B. Determining the Number of Manual Measurements Required to Improve Peat Thickness Estimations by Ground Penetrating Radar. Earth Surf. Process. Landforms 2009, 34, 377-383. [CrossRef]

190. Raynolds, M.K.; Walker, D.A. Effects of Deglaciation on Circumpolar Distribution of Arctic Vegetation. Can. J. Remote Sens. 2009, 35, 118-129. [CrossRef]

191. Pirie, L.; Francis, C.; Johnston, V. Evaluating the Potential Impact of a Gas Pipeline on Whimbrel Breeding Habitat in the Outer Mackenzie Delta, Northwest Territories. Avian Conserv. Ecol. 2009, 4, 2. [CrossRef]

192. Spooner, I.; Stevens, G.; Morrow, J.; Pufahl, P.; Grieve, R.; Raeside, R.; Pilon, J.; Stanley, C.; Barr, S.; McMullin, D. Identification of the Bloody Creek Structure, a Possible Impact Crater in Southwestern Nova Scotia, Canada. Meteorit. Planet. Sci. 2009, 44, 1193-1202. [CrossRef]

193. Clark, R.B.; Creed, I.F.; Sass, G.Z. Mapping Hydrologically Sensitive Areas on the Boreal Plain: A Multitemporal Analysis of ERS Synthetic Aperture Radar Data. Int. J. Remote Sens. 2009, 30, 2619-2635. [CrossRef]

194. Fang, X.; Pomeroy, J.W. Modelling Blowing Snow Redistribution to Prairie Wetlands. Hydrol. Process. Int. J. 2009, 23, 2557-2569. [CrossRef]

195. Touzi, R.; Deschamps, A.; Demers, A.M.; Rother, G. The Touzi Decomposition for Wetland Classification Using Polarimetric C-Band SAR. In Proceedings of the 4th Int. Workshop Sci. Appl. SAR Polarimetry Polarimetric Interferometry (PolInSAR), Frascati, Italy, 26-30 January 2009; p. 261.

196. Touzi, R.; Deschamps, A.; Rother, G. Phase of Target Scattering for Wetland Characterization Using Polarimetric C-Band SAR. IEEE Trans. Geosci. Remote Sens. 2009, 47, 3241-3261. [CrossRef]

197. Maxie, A.J.; Hussey, K.F.; Lowe, S.J.; Middel, K.R.; Pond, B.A.; Obbard, M.E.; Patterson, B.R. A Comparison of Forest Resource Inventory, Provincial Land Cover Maps and Field Surveys for Wildlife Habitat Analysis in the Great Lakes-St. Lawrence Forest. For. Chron. 2010, 86, 77-86. [CrossRef]

198. Soverel, N.O.; Coops, N.C.; White, J.C.; Wulder, M.A. Characterizing the Forest Fragmentation of Canada's National Parks Environ. Monit. Assess. 2010, 164, 481-499. [CrossRef] [PubMed]

199. Levrel, G.; Rousseau, A.N. Étalonnage de Sondes FDR («frequency Domain Reflectometry») Sur Les Cinq Premiers Centimètres Des Sols et Des Couverts de Bryophytes de Deux Tourbières Minérotrophes Du Milieu Boréal Québécois (Canada). Can. J. Remote Sens. 2010, 36, 313-331. [CrossRef]

200. Sannel, A.B.K.; Brown, I.A. High-Resolution Remote Sensing Identification of Thermokarst Lake Dynamics in a Subarctic Peat Plateau Complex. Can. J. Remote Sens. 2010, 36, S26-S40. [CrossRef]

201. Neta, T.; Cheng, Q.; Bello, R.L.; Hu, B. Lichens and Mosses Moisture Content Assessment through High-spectral Resolution Remote Sensing Technology: A Case Study of the Hudson Bay Lowlands, Canada. Hydrol. Process. 2010, 24, 2617-2628. [CrossRef]

202. Midwood, J.D.; Chow-Fraser, P. Mapping Floating and Emergent Aquatic Vegetation in Coastal Wetlands of Eastern Georgian Bay, Lake Huron, Canada. Wetlands 2010, 30, 1141-1152. [CrossRef]

203. Touzi, R.; Gosselin, G. Peatland Subsurface Water Flow Monitoring Using Polarimetric L-Band PALSAR. In Proceedings of the 2010 IEEE International Geoscience and Remote Sensing Symposium, Honolulu, HI, USA, 25-30 July 2010; IEEE: Piscataway, NJ, USA, 2010; pp. 750-753.

204. Fang, X.; Pomeroy, J.W.; Westbrook, C.J.; Guo, X.; Minke, A.G.; Brown, T. Prediction of Snowmelt Derived Streamflow in a Wetland Dominated Prairie Basin. Hydrol. Earth Syst. Sci. 2010, 14, 991-1006. [CrossRef]

205. Brisco, B.; Kapfer, M.; Hirose, T.; Tedford, B.; Liu, J. Evaluation of C-Band Polarization Diversity and Polarimetry for Wetland Mapping. Can. J. Remote Sens. 2011, 37, 82-92. [CrossRef]

206. Crowell, N.; Webster, T.; O’Driscoll, N.J. GIS Modelling of Intertidal Wetland Exposure Characteristics. J. Coast. Res. 2011, 27, 44-51. [CrossRef]

207. Quinton, W.L.; Hayashi, M.; Chasmer, L.E. Permafrost-Thaw-Induced Land-Cover Change in the Canadian Subarctic: Implications for Water Resources. Hydrol. Process. 2011, 25, 152-158. [CrossRef]

208. Rokitnicki-Wojcik, D.; Wei, A.; Chow-Fraser, P. Transferability of Object-Based Rule Sets for Mapping Coastal High Marsh Habitat among Different Regions in Georgian Bay, Canada. Wetl. Ecol. Manag. 2011, 19, 223-236. [CrossRef]

209. Muskett, R.R.; Romanovsky, V.E. Alaskan Permafrost Groundwater Storage Changes Derived from GRACE and Ground Measurements. Remote Sens. 2011, 3, 378-397. [CrossRef]

210. Chen, B.; Coops, N.C.; Fu, D.; Margolis, H.A.; Amiro, B.D.; Barr, A.G.; Black, T.A.; Arain, M.A.; Bourque, C.P.-A.; Flanagan, L.B. Assessing Eddy-Covariance Flux Tower Location Bias across the Fluxnet-Canada Research Network Based on Remote Sensing and Footprint Modelling. Agric. For. Meteorol. 2011, 151, 87-100. [CrossRef]

211. Neta, T.; Cheng, Q.; Bello, R.L.; Hu, B. Development of New Spectral Reflectance Indices for the Detection of Lichens and Mosses Moisture Content in the Hudson Bay Lowlands, Canada. Hydrol. Process. 2011, 25, 933-944. [CrossRef] 
212. Hogan, D.; Thompson, J.E.; Esler, D.; Boyd, W.S. Discovery of Important Postbreeding Sites for Barrow's Goldeneye in the Boreal Transition Zone of Alberta. Waterbirds Int. J. Waterbird Biol. 2011, 34, 261-268. [CrossRef]

213. Shook, K.R.; Pomeroy, J.W. Memory Effects of Depressional Storage in Northern Prairie Hydrology. Hydrol. Process. 2011, 25, 3890-3898. [CrossRef]

214. Fraser, S.; Storie, S. Detecting Historic Wetlands Using Radar Data: A Review. In Proceedings of the 2012 IEEE International Geoscience and Remote Sensing Symposium, Munich, Germany, 22-27 July 2012; IEEE: Piscataway, NJ, USA, $2012 ;$ pp. $772-774$.

215. Guo, X.; Pomeroy, J.W.; Fang, X.; Lowe, S.; Li, Z.; Westbrook, C.; Minke, A. Effects of Classification Approaches on CRHM Model Performance. Remote Sens. Lett. 2012, 3, 39-47. [CrossRef]

216. Barker, R.; King, D.J. Blanding's Turtle (Emydoidea Blandingii) Potential Habitat Mapping Using Aerial Orthophotographic Imagery and Object Based Classification. Remote Sens. 2012, 4, 194-219. [CrossRef]

217. Kaya, S.; Brisco, B.; Cull, A.; Gallant, A.; Sadinski, W.; Thompson, D. Canadian SAR Remote Sensing for the Terrestrial Wetland Global Change Research Network (TWGCRN). In Proceedings of the Remote Sensing and Hydrology 2010 Symposium, Jackson Hole, WY, USA, 27-30 September 2010; Volume 2730.

218. Pivot, F.C. C-Band SAR Imagery for Snow-Cover Monitoring at Treeline, Churchill, Manitoba, Canada. Remote Sens. 2012, 4 , 2133-2155. [CrossRef]

219. Midwood, J.D.; Chow-Fraser, P. Changes in Aquatic Vegetation and Fish Communities Following 5 Years of Sustained Low Water Levels in Coastal Marshes of Eastern G Eorgian B Ay, L Ake H Uron. Glob. Chang. Biol. 2012, 18, 93-105. [CrossRef]

220. Gala, T.S.; Melesse, A.M. Monitoring Prairie Wet Area with an Integrated LANDSAT ETM+, RADARSAT-1 SAR and Ancillary Data from LIDAR. Catena 2012, 95, 12-23. [CrossRef]

221. Chen, W.; Foy, N.; Olthof, I.; Latifovic, R.; Zhang, Y.; Li, J.; Fraser, R.; Chen, Z.; McLennan, D.; Poitevin, J. Evaluating and Reducing Errors in Seasonal Profiles of AVHRR Vegetation Indices over a Canadian Northern National Park Using a Cloudiness Index. Int. J. Remote Sens. 2013, 34, 4320-4343. [CrossRef]

222. Doiron, M.; Legagneux, P.; Gauthier, G.; Lévesque, E. Broad-scale Satellite N Ormalized D Ifference V Egetation I Ndex Data Predict Plant Biomass and Peak Date of Nitrogen Concentration in A Rctic Tundra Vegetation. Appl. Veg. Sci. 2013, 16, 343-351. [CrossRef]

223. McClymont, A.F.; Hayashi, M.; Bentley, L.R.; Christensen, B.S. Geophysical Imaging and Thermal Modeling of Subsurface Morphology and Thaw Evolution of Discontinuous Permafrost. J. Geophys. Res. Earth Surf. 2013, 118, 1826-1837. [CrossRef]

224. Lapointe, J.; Imbeau, L.; Tremblay, J.A.; Maisonneuve, C.; Mazerolle, M.J. Habitat Use by Female Peregrine Falcons (Falco Peregrinus) in an Agricultural Landscape. Auk 2013, 130, 381-391. [CrossRef]

225. Huschle, G.; Toepfer, J.E.; Douglas, D.C. Migration and Wintering Areas of American Bitterns (Botaurus Lentiginosus) That Summer in Central North America as Determined by Satellite and Radio Telemetry, 1998-2003. Waterbirds 2013, 36, 300-309. [CrossRef]

226. Mattar, K.E. Monitoring the Persistence of Odd and Even Scatterers in a Mixed Urban Environment Using Pol-InSAR Acquisitions. Can. J. Remote Sens. 2013, 39, 34-41. [CrossRef]

227. Jacome, A.; Bernier, M.; Chokmani, K.; Gauthier, Y.; Poulin, J.; De Sève, D. Monitoring Volumetric Surface Soil Moisture Content at the La Grande Basin Boreal Wetland by Radar Multi Polarization Data. Remote Sens. 2013, 5, 4919-4941. [CrossRef]

228. Banks, S.N.; King, D.J.; Merzouki, A.; Duffe, J. Assessing RADARSAT-2 for Mapping Shoreline Cleanup and Assessment Technique (SCAT) Classes in the Canadian Arctic. Can. J. Remote Sens. 2014, 40, 243-267. [CrossRef]

229. Banks, S.N.; King, D.J.; Merzouki, A.; Duffe, J. Characterizing Scattering Behaviour and Assessing Potential for Classification of Arctic Shore and Near-Shore Land Covers with Fine Quad-Pol RADARSAT-2 Data. Can. J. Remote Sens. 2014, 40, 291-314. [CrossRef]

230. Ahern, F.J.; Brisco, B.; Murnaghan, K.; White, L.; Wdowinski, S.; Hong, S.-H.; Atwood, D. PolSAR Imaging of Wetlands: New Insights into Backscatter Physics. In Proceedings of the 2014 IEEE Geoscience and Remote Sensing Symposium, Quebec City, QC, Canada, 13-18 July 2014; IEEE: Piscataway, NJ, USA, 2014; pp. 1171-1174.

231. Armenakis, C.; Alexandridis, T.; Nirupama, N.; Zalidis, G. A Study on Degradation of Coastal Wetlands Using Examples from Greece and Canada. Int. J. Ecol. Dev. 2014, 29.

232. Ely, C.R.; Sladen, W.J.L.; Wilson, H.M.; Savage, S.E.; Sowl, K.M.; Henry, B.; Schwitters, M.; Snowdon, J. Delineation of Tundra Swan Cygnus c. Columbianus Populations in North America: Geographic Boundaries and Interchange. Wildfowl 2014, 64, 132-147.

233. Chabot, D.; Carignan, V.; Bird, D.M. Measuring Habitat Quality for Least Bitterns in a Created Wetland with Use of a Small Unmanned Aircraft. Wetlands 2014, 34, 527-533. [CrossRef]

234. Cable, J.W.; Kovacs, J.M.; Shang, J.; Jiao, X. Multi-Temporal Polarimetric RADARSAT-2 for Land Cover Monitoring in Northeastern Ontario, Canada. Remote Sens. 2014, 6, 2372-2392. [CrossRef]

235. Nelson, T.A.; Coops, N.C.; Wulder, M.A.; Perez, L.; Fitterer, J.; Powers, R.; Fontana, F. Predicting Climate Change Impacts to the Canadian Boreal Forest. Diversity 2014, 6, 133-157. [CrossRef]

236. Clare, S.; Creed, I.F. Tracking Wetland Loss to Improve Evidence-Based Wetland Policy Learning and Decision Making. Wetl. Ecol. Manag. 2014, 22, 235-245. [CrossRef]

237. Bourgeau-Chavez, L.; Endres, S.; Battaglia, M.; Miller, M.E.; Banda, E.; Laubach, Z.; Higman, P.; Chow-Fraser, P.; Marcaccio, J. Development of a Bi-National Great Lakes Coastal Wetland and Land Use Map Using Three-Season PALSAR and Landsat Imagery. Remote Sens. 2015, 7, 8655-8682. [CrossRef] 
238. Umbanhowar Jr, C.E.; Camill, P.; Edlund, M.B.; Geiss, C.; Henneghan, P.; Passow, K. Lake-Landscape Connections at the Forest-Tundra Transition of Northern Manitoba. Inland Waters 2015, 5, 57-74. [CrossRef]

239. Sagin, J.; Sizo, A.; Wheater, H.; Jardine, T.D.; Lindenschmidt, K.-E. A Water Coverage Extraction Approach to Track Inundation in the Saskatchewan River Delta, Canada. Int. J. Remote Sens. 2015, 36, 764-781. [CrossRef]

240. Dingle Robertson, L.; King, D.J.; Davies, C. Assessing Land Cover Change and Anthropogenic Disturbance in Wetlands Using Vegetation Fractions Derived from Landsat 5 TM Imagery (1984-2010). Wetlands 2015, 35, 1077-1091. [CrossRef]

241. Kalacska, M.; Lalonde, M.; Moore, T.R. Estimation of Foliar Chlorophyll and Nitrogen Content in an Ombrotrophic Bog from Hyperspectral Data: Scaling from Leaf to Image. Remote Sens. Environ. 2015, 169, 270-279. [CrossRef]

242. Kotchi, S.O.; Brazeau, S.; Turgeon, P.; Pelcat, Y.; Légaré, J.; Lavigne, M.-P.; Essono, F.N.; Fournier, R.A.; Michel, P. Evaluation of Earth Observation Systems for Estimating Environmental Determinants of Microbial Contamination in Recreational Waters. IEEE J. Sel. Top. Appl. Earth Obs. Remote Sens. 2015, 8, 3730-3741. [CrossRef]

243. Tougas-Tellier, M.; Morin, J.; Hatin, D.; Lavoie, C. Freshwater Wetlands: Fertile Grounds for the Invasive P Hragmites Australis in a Climate Change Context. Ecol. Evol. 2015, 5, 3421-3435. [CrossRef]

244. Messmer, D.J.; Petrie, S.A.; Badzinski, S.S.; Gloutney, M.L.; Schummer, M.L. Habitat Associations of Breeding Mallards and Canada Geese in Southern Ontario, Canada. Wildl. Soc. Bull. 2015, 39, 543-552. [CrossRef]

245. Brisco, B.; Ahern, F.; Hong, S.-H.; Wdowinski, S.; Murnaghan, K.; White, L.; Atwood, D.K. Polarimetric Decompositions of Temperate Wetlands at C-Band. IEEE J. Sel. Top. Appl. Earth Obs. Remote Sens. 2015, 8, 3585-3594. [CrossRef]

246. Muster, S.; Langer, M.; Abnizova, A.; Young, K.L.; Boike, J. Spatio-Temporal Sensitivity of MODIS Land Surface Temperature Anomalies Indicates High Potential for Large-Scale Land Cover Change Detection in Arctic Permafrost Landscapes. Remote Sens. Environ. 2015, 168, 1-12. [CrossRef]

247. Jiao, X.; Zhang, Y.; Guindon, B. Synergistic Use of RADARSAT-2 Ultra Fine and Fine Quad-Pol Data to Map Oilsands Infrastructure Land: Object-Based Approach. Int. J. Appl. Earth Obs. Geoinf. 2015, 38, 193-203. [CrossRef]

248. Li-Chee-Ming, J.; Murnaghan, K.; Sherman, D.; Poncos, V.; Brisco, B.; Armenakis, C. Validation of Spaceborne Radar Surface Water Mapping with Optical SUAS Images. Int. Arch. Photogramm. Remote Sens. Spat. Inf. Sci. 2015, 40, 363. [CrossRef]

249. Thompson, S.D.; Nelson, T.A.; Giesbrecht, I.; Frazer, G.; Saunders, S.C. Data-Driven Regionalization of Forested and Non-Forested Ecosystems in Coastal British Columbia with LiDAR and RapidEye Imagery. Appl. Geogr. 2016, 69, 35-50. [CrossRef]

250. Marcaccio, J.V.; Chow-Fraser, P. Mapping Options to Track Invasive Phragmites Australis in the Great Lakes Basin in Canada. In Proceedings of the 3rd International Conference "Water Resources and Wetlands", Tulcea, Romania, 8-10 September 2014.

251. Chasmer, L.; Hopkinson, C.; Montgomery, J.; Petrone, R. A Physically Based Terrain Morphology and Vegetation Structural Classification for Wetlands of the Boreal Plains, Alberta, Canada. Can. J. Remote Sens. 2016, 42, 521-540. [CrossRef]

252. Spence, C.; Mengistu, S. Deployment of an Unmanned Aerial System to Assist in Mapping an Intermittent Stream. Hydrol. Process. 2016, 30, 493-500. [CrossRef]

253. Shinneman, A.L.C.; Umbanhowar, C.E.; Edlund, M.B.; Hobbs, W.O.; Camill, P.; Geiss, C. Diatom Assemblages Reveal RegionalScale Differences in Lake Responses to Recent Climate Change at the Boreal-Tundra Ecotone, Manitoba, Canada. J. Paleolimnol. 2016, 56, 275-298. [CrossRef]

254. Finger, T.A.; Afton, A.D.; Schummer, M.L.; Petrie, S.A.; Badzinski, S.S.; Johnson, M.A.; Szymanski, M.L.; Jacobs, K.J.; Olsen, G.H.; Mitchell, M.A. Environmental Factors Influence Lesser Scaup Migration Chronology and Population Monitoring. J. Wildl. Manag. 2016, 80, 1437-1449. [CrossRef]

255. Miller, S.M.; Commane, R.; Melton, J.R.; Andrews, A.E.; Benmergui, J.; Dlugokencky, E.J.; Janssens-Maenhout, G.; Michalak, A.M.; Sweeney, C.; Worthy, D.E.J. Evaluation of Wetland Methane Emissions across North America Using Atmospheric Data and Inverse Modeling. Biogeosciences 2016, 13, 1329-1339. [CrossRef]

256. Kross, A.; Seaquist, J.W.; Roulet, N.T. Light Use Efficiency of Peatlands: Variability and Suitability for Modeling Ecosystem Production. Remote Sens. Environ. 2016, 183, 239-249. [CrossRef]

257. Shodimu, O.; Al-Tahir, R. Modeling Land Cover Dynamics to Assess the Sustainability of Wetland Services: A Case Study of the Grand Lake Meadows, Canada. In Proceedings of the IOP Conference Series: Earth and Environmental Science, Halifax, NS, Canada, 5-9 October 2015; Volume 34, p. 12033.

258. Schmitt, A.; Wendleder, A.; Murnaghan, K.; Brisco, B.; Poncos, V. Multi-Sensor Wetland Mapping over the Peace Athabasca Delta. In Proceedings of the EUSAR 2016: 11th European Conference on Synthetic Aperture Radar, Hamburg, Germany, 6-9 June 2016; pp. 1-4.

259. Emmerton, C.A.; St. Louis, V.L.; Humphreys, E.R.; Gamon, J.A.; Barker, J.D.; Pastorello, G.Z. Net Ecosystem Exchange of CO 2 with Rapidly Changing High Arctic Landscapes. Glob. Chang. Biol. 2016, 22, 1185-1200. [CrossRef]

260. Serran, J.N.; Creed, I.F. New Mapping Techniques to Estimate the Preferential Loss of Small Wetlands on Prairie Landscapes. Hydrol. Process. 2016, 30, 396-409. [CrossRef]

261. Bolanos, S.; Stiff, D.; Brisco, B.; Pietroniro, A. Operational Surface Water Detection and Monitoring Using Radarsat 2. Remote Sens. 2016, 8, 285. [CrossRef]

262. Morsy, S.; Shaker, A.; El-Rabbany, A. Potential Use of Multispectral Airborne LiDAR Data in Land Cover Classification. In Proceedings of the Asian conference on Remote Sensing (ACRS), Colombo, Sri Lanka, 17-21 October 2016; pp. 17-21.

263. van der Kamp, G.; Hayashi, M.; Bedard-Haughn, A.; Pennock, D. Prairie Pothole Wetlands-Suggestions for Practical and Objective Definitions and Terminology. Wetlands 2016, 36, 229-235. [CrossRef] 
264. Sizo, A.; Noble, B.F.; Bell, S. Strategic Environmental Assessment Framework for Landscape-Based, Temporal Analysis of Wetland Change in Urban Environments. Environ. Manag. 2016, 57, 696-710. [CrossRef] [PubMed]

265. Ullmann, T.; Schmitt, A.; Jagdhuber, T. Two Component Decomposition of Dual Polarimetric HH/VV SAR Data: Case Study for the Tundra Environment of the Mackenzie Delta Region, Canada. Remote Sens. 2016, 8, 1027. [CrossRef]

266. Amani, M.; Salehi, B.; Mahdavi, S.; Granger, J.; Brisco, B. Evaluation of Multi-Temporal Landsat 8 Data for Wetland Classification in Newfoundland, Canada. In Proceedings of the International Geoscience and Remote Sensing Symposium (IGARSS), Fort Worth, TX, USA, 23-28 July 2017; pp. 6229-6231.

267. Mahdianpari, M.; Salehi, B.; Mohammadimanesh, F. The Effect of PolSAR Image De-Speckling on Wetland Classification: Introducing a New Adaptive Method. Can. J. Remote Sens. 2017, 43, 485-503. [CrossRef]

268. Lovitt, J.; Rahman, M.M.; McDermid, G.J. Assessing the Value of UAV Photogrammetry for Characterizing Terrain in Complex Peatlands. Remote Sens. 2017, 9, 715. [CrossRef]

269. Kim, S.; Brisco, B.; Poncos, V. Inundation Extent Monitoring with Smap Data for Carbon Studies. In Proceedings of the International Geoscience and Remote Sensing Symposium (IGARSS), Fort Worth, TX, USA, 23-28 July 2017; pp. 5693-5696.

270. Mohammadimanesh, F.; Bahram, S.; Brisco, B.; Mahdianpari, M. Monitoring of Wetland Water Levels in Newfoundland and Labrador Using Interferometric Synthetic Aperture Radar (INSAR) Technique. In Proceedings of the Asprs IGTF2017, Baltimore MD, USA, 12-16 March 2017.

271. Dabboor, M.; Brisco, B.; Banks, S.; Murnaghan, K.; White, L. Multitemporal Monitoring of Wetlands Using Simulated Radarsat Constellation Mission Compact Polarimetric SAR Data. In Proceedings of the International Geoscience and Remote Sensing Symposium (IGARSS), Fort Worth, TX, USA, 23-28 July 2017; pp. 4586-4589.

272. Chabot, D.; Dillon, C.; Ahmed, O.; Shemrock, A. Object-Based Analysis of Uas Imagery to Map Emergent and Submerged Invasive Aquatic Vegetation: A Case Study. J. Unmanned Veh. Syst. 2016, 5, 27-33. [CrossRef]

273. Perreault, N.; Lévesque, E.; Fortier, D.; Gratton, D.; Lamarque, L.J. Remote Sensing Evaluation of High Arctic Wetland Depletion Following Permafrost Disturbance by Thermo-Erosion Gullying Processes. Arct. Sci. 2017, 3, 237-253. [CrossRef]

274. Ullmann, T.; Banks, S.N.; Schmitt, A.; Jagdhuber, T. Scattering Characteristics of X-, C- and L-Band Polsar Data Examined for the Tundra Environment of the Tuktoyaktuk Peninsula, Canada. Appl. Sci. 2017, 7, 595. [CrossRef]

275. Brisco, B.; Ahern, F.; Murnaghan, K.; White, L.; Canisus, F.; Lancaster, P. Seasonal Change in Wetland Coherence as an Aid to Wetland Monitoring. Remote Sens. 2017, 9, 158. [CrossRef]

276. Mohammadimanesh, F.; Salehi, B.; Mahdianpari, M.; Motagh, M.; Brisco, B. An Efficient Feature Optimization for Wetland Mapping by Synergistic Use of SAR Intensity, Interferometry, and Polarimetry Data. Int. J. Appl. Earth Obs. Geoinf. 2018, 73, 450-462. [CrossRef]

277. D'Acunha, B.; Lee, S.C.; Johnson, M.S. Ecohydrological Responses to Rewetting of a Highly Impacted Raised Bog Ecosystem. Ecohydrology 2018, 11, e1922. [CrossRef]

278. Ahern, F.; Brisco, B.; Murnaghan, K.; Lancaster, P.; Atwood, D.K. Insights into Polarimetric Processing for Wetlands from Backscatter Modeling and Multi-Incidence Radarsat-2 Data. IEEE J. Sel. Top. Appl. Earth Obs. Remote Sens. 2018, 11, 3040-3050. [CrossRef]

279. Whitley, M.A.; Frost, G.V.; Jorgenson, M.T.; Macander, M.J.; Maio, C.V.; Winder, S.G. Assessment of LiDAR and Spectral Techniques for High-Resolution Mapping of Sporadic Permafrost on the Yukon-Kuskokwim Delta, Alaska. Remote Sens. 2018, 10, 258. [CrossRef]

280. Jorgenson, T.M.; Frost, G.V.; Dissing, D. Drivers of Landscape Changes in Coastal Ecosystems on the Yukon-Kuskokwim Delta, Alaska. Remote Sens. 2018, 10, 1280. [CrossRef]

281. Ward, E.M.; Gorelick, S.M. Drying Drives Decline in Muskrat Population in the Peace-Athabasca Delta, Canada. Environ. Res. Lett. 2018, 13, 124026. [CrossRef]

282. Potter, C. Ecosystem Carbon Emissions from 2015 Forest Fires in Interior Alaska. Carbon Balance Manag. 2018, 13, 1-10. [CrossRef]

283. Campbell, T.K.F.; Lantz, T.C.; Fraser, R.H. Impacts of Climate Change and Intensive Lesser Snow Goose (Chen Caerulescens Caerulescens) Activity on Surfacewater in High Arctic Pond Complexes. Remote Sens. 2018, 10, 1892. [CrossRef]

284. Blanchette, M.; Rousseau, A.N.; Poulin, M. Mapping Wetlands and Land Cover Change with Landsat Archives: The Added Value of Geomorphologic Data: Cartographie de La Dynamique Spatio-Temporelle Des Milieux Humides à Partir d'archives Landsat: La Valeur Ajoutée de Données Géomorphologiques. Can. J. Remote Sens. 2018, 44, 337-356. [CrossRef]

285. Warren, R.K.; Pappas, C.; Helbig, M.; Chasmer, L.E.; Berg, A.A.; Baltzer, J.L.; Quinton, W.L.; Sonnentag, O. Minor Contribution of Overstorey Transpiration to Landscape Evapotranspiration in Boreal Permafrost Peatlands. Ecohydrology 2018, 11, e1975. [CrossRef]

286. DeLancey, E.R.; Kariyeva, J.; Cranston, J.; Brisco, B. Monitoring Hydro Temporal Variability in Alberta, Canada with MultiTemporal Sentinel-1 SAR Data. Can. J. Remote Sens. 2018, 44, 1-10. [CrossRef]

287. Chasmer, L.E.; Devito, K.J.; Hopkinson, C.D.; Petrone, R.M. Remote Sensing of Ecosystem Trajectories as a Proxy Indicator for Watershed Water Balance. Ecohydrology 2018, 11, e1987. [CrossRef]

288. Montgomery, J.S.; Hopkinson, C.; Brisco, B.; Patterson, S.; Rood, S.B. Wetland Hydroperiod Classification in the Western Prairies Using Multitemporal Synthetic Aperture Radar. Hydrol. Process. 2018, 32, 1476-1490. [CrossRef] 
289. Merchant, M.A.; Warren, R.K.; Edwards, R.; Kenyon, J.K. An Object-Based Assessment of Multi-Wavelength SAR, Optical Imagery and Topographical Datasets for Operational Wetland Mapping in Boreal Yukon, Canada. Can. J. Remote Sens. 2019, 45, 308-332. [CrossRef]

290. Judah, A.; Hu, B. The Integration of Multi-Source Remotely-Sensed Data in Support of the Classification of Wetlands. Remote Sens. 2019, 11, 1537. [CrossRef]

291. Pitcher, L.H.; Pavelsky, T.M.; Smith, L.C.; Moller, D.K.; Altenau, E.H.; Allen, G.H.; Lion, C.; Butman, D.; Cooley, S.W.; Fayne, J.V.; et al. AirSWOT InSAR Mapping of Surface Water Elevations and Hydraulic Gradients Across the Yukon Flats Basin, Alaska. Water Resour. Res. 2019, 55, 937-953. [CrossRef]

292. Gonsamo, A.; Ter-Mikaelian, M.T.; Chen, J.M.; Chen, J. Does Earlier and Increased Spring Plant Growth Lead to Reduced Summer Soil Moisture and Plant Growth on Landscapes Typical of Tundra-Taiga Interface? Remote Sens. 2019, 11, 1989. [CrossRef]

293. Westwood, A.R.; Staicer, C.; Sólymos, P.; Haché, S.; Fontaine, T.; Bayne, E.M.; Mazerolle, D. Estimating the Conservation Value of Protected Areas in Maritime Canada for Two Species at Risk: The Olive-Sided Flycatcher (Contopus Cooperi) and Canada Warbler (Cardellina Canadensis). Avian Conserv. Ecol. 2019, 14, 16. [CrossRef]

294. Brisco, B.; Shelat, Y.; Murnaghan, K.; Montgomery, J.; Fuss, C.; Olthof, I.; Hopkinson, C.; Deschamps, A.; Poncos, V. Evaluation of C-Band SAR for Identification of Flooded Vegetation in Emergency Response Products. Can. J. Remote Sens. 2019, 45, 73-87. [CrossRef]

295. Jensen, D.; Simard, M.; Cavanaugh, K.; Sheng, Y.; Fichot, C.G.; Pavelsky, T.; Twilley, R. Improving the Transferability of Suspended Solid Estimation in Wetland and Deltaic Waters with an Empirical Hyperspectral Approach. Remote Sens. 2019, $11,1629$. [CrossRef]

296. Palumbo, M.D.; Petrie, S.A.; Schummer, M.; Rubin, B.D.; Bonner, S. Mallard Resource Selection Trade-Offs in a Heterogeneous Environment during Autumn and Winter. Ecol. Evol. 2019, 9, 1798-1808. [CrossRef] [PubMed]

297. Montgomery, J.; Brisco, B.; Chasmer, L.; Devito, K.; Cobbaert, D.; Hopkinson, C. SAR and Lidar Temporal Data Fusion Approaches to Boreal Wetland Ecosystem Monitoring. Remote Sens. 2019, 11, 161. [CrossRef]

298. Lane, D.; McCarter, C.P.R.; Richardson, M.; McConnell, C.; Field, T.; Yao, H.; Arhonditsis, G.; Mitchell, C.P.J. Wetlands and Low-Gradient Topography Are Associated with Longer Hydrologic Transit Times in Precambrian Shield Headwater Catchments. Hydrol. Process. 2020, 34, 598-614. [CrossRef]

299. Mahdianpari, M.; Jafarzadeh, H.; Granger, J.E.; Mohammadimanesh, F.; Brisco, B.; Salehi, B.; Homayouni, S.; Weng, Q. A Large-Scale Change Monitoring of Wetlands Using Time Series Landsat Imagery on Google Earth Engine: A Case Study in Newfoundland. GISci. Remote Sens. 2020, 57, 1102-1124. [CrossRef]

300. Chen, Z.; White, L.; Banks, S.; Behnamian, A.; Montpetit, B.; Pasher, J.; Duffe, J.; Bernard, D. Characterizing Marsh Wetlands in the Great Lakes Basin with C-Band InSAR Observations. Remote Sens. Environ. 2020, 242, 111750. [CrossRef]

301. Merchant, M.; Haas, C. High-Latitude Wetland Mapping Using Multidate and Multisensor Earth Observation Data: A Case Study in the Northwest Territories. J. Appl. Remote Sens. 2020, 14, 034511. [CrossRef]

302. Siles, G.; Trudel, M.; Peters, D.L.; Leconte, R. Hydrological Monitoring of High-Latitude Shallow Water Bodies from HighResolution Space-Borne D-InSAR. Remote Sens. Environ. 2020, 236, 111444. [CrossRef]

303. White, L.; McGovern, M.; Hayne, S.; Touzi, R.; Pasher, J.; Duffe, J. Investigating the Potential Use of RADARSAT-2 and UAS Imagery for Monitoring the Restoration of Peatlands. Remote Sens. 2020, 12, 2383. [CrossRef]

304. Hawkes, V.C.; Miller, M.T.; Novoa, J.; Ibeke, E.; Martin, J.P. Opportunistic Wetland Formation, Characterization, and Quantification on Landforms Reclaimed to Upland Ecosites in the Athabasca Oil Sands Region. Wetl. Ecol. Manag. 2020, 28, 953-970. [CrossRef]

305. Brisco, B.; Mahdianpari, M.; Mohammadimanesh, F. Hybrid Compact Polarimetric SAR for Environmental Monitoring with the RADARSAT Constellation Mission. Remote Sens. 2020, 12, 1-20. [CrossRef]

306. Larocque, A.; Leblon, B.; Woodward, R.; Bourgeau-Chavez, L. Wetland Mapping in New Brunswick, Canada with Landsat5-Tm, Alos-Palsar, and Radarsat-2 Imagery. ISPRS Ann. Photogramm. Remote Sens. Spat. Inf. Sci. 2020, 5, 301-308. [CrossRef]

307. Ahmed, M.I.; Elshorbagy, A.; Pietroniro, A. A Novel Model for Storage Dynamics Simulation and Inundation Mapping in the Prairies. Environ. Model. Softw. 2020, 133, 104850. [CrossRef]

308. Bahrami, A.; Goïta, K.; Magagi, R. Analysing the Contribution of Snow Water Equivalent to the Terrestrial Water Storage over Canada. Hydrol. Process. 2020, 34, 175-188. [CrossRef]

309. Bergeron, J.; Siles, G.; Leconte, R.; Trudel, M.; Desroches, D.; Peters, D.L. Assessing the Capabilities of the Surface Water and Ocean Topography (SWOT) Mission for Large Lake Water Surface Elevation Monitoring under Different Wind Conditions. Hydrol. Earth Syst. Sci. 2020, 24, 5985-6000. [CrossRef]

310. Mahoney, C.; Merchant, M.; Boychuk, L.; Hopkinson, C.; Brisco, B. Automated SAR Image Thresholds for Water Mask Production in Alberta's Boreal Region. Remote Sens. 2020, 12, 2223. [CrossRef]

311. Wulder, M.A.; Hermosilla, T.; White, J.C.; Coops, N.C. Biomass Status and Dynamics over Canada's Forests: Disentangling Disturbed Area from Associated Aboveground Biomass Consequences. Environ. Res. Lett. 2020, 15, 94093. [CrossRef]

312. Janardanan, R.; Maksyutov, S.; Tsuruta, A.; Wang, F.; Tiwari, Y.K.; Valsala, V.; Ito, A.; Yoshida, Y.; Kaiser, J.W.; Janssens-Maenhout, G.; et al. Country-Scale Analysis of Methane Emissions with a High-Resolution Inverse Model Using GOSAT and Surface Observations. Remote Sens. 2020, 12, 375. [CrossRef]

313. O'Sullivan, A.M.; Devito, K.J.; Ogilvie, J.; Linnansaari, T.; Pronk, T.; Allard, S.; Curry, R.A. Effects of Topographic Resolution and Geologic Setting on Spatial Statistical River Temperature Models. Water Resour. Res. 2020, 56, e2020WR028122. [CrossRef] 
314. Olthof, I.; Rainville, T. Evaluating Simulated RADARSAT Constellation Mission (RCM) Compact Polarimetry for Open-Water and Flooded-Vegetation Wetland Mapping. Remote Sens. 2020, 12, 1476. [CrossRef]

315. Wadsworth, E.; Champagne, C.; Berg, A.A. Evaluating the Utility of Remotely Sensed Soil Moisture for the Characterization of Runoff Response over Canadian Watersheds. Can. Water Resour. J. 2020, 45, 77-89. [CrossRef]

316. Amani, M.; Brisco, B.; Mahdavi, S.; Ghorbanian, A.; Moghimi, A.; Delancey, E.R.; Merchant, M.; Jahncke, R.; Fedorchuk, L.; Mui, A.; et al. Evaluation of the Landsat-Based Canadian Wetland Inventory Map Using Multiple Sources: Challenges of Large-Scale Wetland Classification Using Remote Sensing. IEEE J. Sel. Top. Appl. Earth Obs. Remote Sens. 2021, 14, 32-52. [CrossRef]

317. Omari, K.; Chenier, R.; Touzi, R.; Sagram, M. Investigation of C-Band SAR Polarimetry for Mapping a High-Tidal Coastal Environment in Northern Canada. Remote Sens. 2020, 12, 1941. [CrossRef]

318. Sewell, P.D.; Quideau, S.A.; Dyck, M.; Macdonald, E. Long-Term Effects of Harvest on Boreal Forest Soils in Relation to a Remote Sensing-Based Soil Moisture Index. For. Ecol. Manag. 2020, 462, 117986. [CrossRef]

319. Peters, D.; Niemann, O.; Skelly, R. Remote Sensing of Ecosystem Structure: Fusing Passive and Active Remotely Sensed Data to Characterize a Deltaic Wetland Landscape. Remote Sens. 2020, 12, 3819. [CrossRef]

320. Zakharov, I.; Kapfer, M.; Hornung, J.; Kohlsmith, S.; Puestow, T.; Howell, M.; Henschel, M.D. Retrieval of Surface Soil Moisture from Sentinel-1 Time Series for Reclamation of Wetland Sites. IEEE J. Sel. Top. Appl. Earth Obs. Remote Sens. 2020, 13, 3569-3578. [CrossRef]

321. Wulder, M.A.; Hermosilla, T.; Stinson, G.; Gougeon, F.A.; White, J.C.; Hill, D.A.; Smiley, B.P. Satellite-Based Time Series Land Cover and Change Information to Map Forest Area Consistent with National and International Reporting Requirements. Forestry 2020, 93, 331-343. [CrossRef]

322. Wang, L.; Marzahn, P.; Bernier, M.; Ludwig, R. Sentinel-1 InSAR Measurements of Deformation over Discontinuous Permafrost Terrain, Northern Quebec, Canada. Remote Sens. Environ. 2020, 248, 111965. [CrossRef]

323. White, L.; Ryerson, R.A.; Pasher, J.; Duffe, J. State of Science Assessment of Remote Sensing of Great Lakes Coastal Wetlands: Responding to an Operational Requirement. Remote Sens. 2020, 12, 3024. [CrossRef]

324. Wu, J.; Gillani, S.S.M.; Wang, M. The Difference in Light Use Efficiency between an Abandoned Peatland Pasture and an Adjacent Boreal Bog in Western Newfoundland, Canada. Wetlands 2020, 40, 733-743. [CrossRef]

325. Haynes, K.M.; Smart, J.; Disher, B.; Carpino, O.; Quinton, W.L. The Role of Hummocks in Re-Establishing Black Spruce Forest Following Permafrost Thaw. Ecohydrology 2021, 14, e2273. [CrossRef]

326. Hopkinson, C.; Fuoco, B.; Grant, T.; Bayley, S.E.; Brisco, B.; Macdonald, R. Wetland Hydroperiod Change along the Upper Columbia River Floodplain, Canada, 1984 to 2019. Remote Sens. 2020, 12, 4084. [CrossRef]

327. Mahdianpari, M.; Granger, J.E.; Mohammadimanesh, F.; Warren, S.; Puestow, T.; Salehi, B.; Brisco, B. Smart Solutions for Smart Cities: Urban Wetland Mapping Using Very-High Resolution Satellite Imagery and Airborne LiDAR Data in the City of St. John's, NL, Canada. J. Environ. Manag. 2021, 280, 111676. [CrossRef] [PubMed] 